University of Konstanz

Department of Economics

\title{
The Globalization-welfare State Nexus Reconsidered
}

Stephanie Meinhard and Niklas Potrafke

Working Paper Series

2011-27 


\title{
The globalization-welfare state nexus reconsidered
}

\author{
Stephanie Meinhard* \\ University of Konstanz \\ Niklas Potrafke* \\ University of Konstanz
}

July 28, 2011

\begin{abstract}
Two hypotheses relate to the globalization-welfare state nexus: the efficiency hypothesis predicts that globalization reduces government sector size and governments' capacity to finance the welfare state. The compensation hypothesis, in contrast, predicts that globalization induces a higher demand for social insurance which results in an extended welfare state. Empirical evidence on the globalization-welfare state nexus is mixed. We re-examine the evidence by investigating a yearly panel dataset of 186 countries for the 1970-2004 period. We use data compiled by the Penn World Tables on government sector size and employ the KOF index of globalization. The results show that globalization increased government sectors around the world. Social globalization especially had a positive influence. Globalization-induced effects were stronger in OECD countries. Overall globalization and economic globalization reduced the relative price of government expenditures. These findings suggest that globalization does not jeopardize the welfare state at all.
\end{abstract}

Keywords: globalization, size of government, welfare state

JEL Classification: F57, I38, O11, O57, C23

\footnotetext{
${ }^{*}$ University of Konstanz, Department of Economics, Box 138, D-78457 Konstanz, Germany, Phone: + 49753188 2137, Fax:+49 753188 3130. Email: st..meinhard@gmx.de

** University of Konstanz, Department of Economics, Box 138, D-78457 Konstanz, Germany, Phone: +49753188

2137, Fax: + 49753188 3130. Email: niklas.potrafke@uni-konstanz.de

We thank Robert Hofmeister, Winfried Pohlmeier, Heinrich Ursprung and two anonymous referees for helpful comments and suggestions. Felix Weber has provided excellent research assistance.
} 


\section{Introduction}

Scholars have different views on how globalization may influence the size of government and the welfare state. For several years the established opinion was that trade liberalization and factor mobility create competition between national governments, leading to a downward pressure on tax rates and therefore to a reduction of fiscal power. As a consequence, a smaller size of government and a retrenchment of the welfare state were predicted (via the supply side or efficiency effect). In contrast, Rodrik (1998) found a positive relationship between the openness of an economy and the extent of government expenditures, contradicting the former opinion of a globalization-induced retrenchment of the government sector and the welfare state. He argued that global economic integration leads to a higher external risk which has to be compensated by higher government spending working as a social insurance device (via the demand side or compensation effect). Schulze and Ursprung (1999) and Ursprung (2008), for example, provide encompassing surveys on the globalization-welfare state nexus. ${ }^{1}$

Many scholars have investigated the globalization-welfare state nexus empirically by using various measures for the size of government, the welfare state, and globalization. The results are mixed. The existing studies do, however, suffer from fairly small sample sizes and except Dreher 2006a, Dreher et al. 2008a, 2008b - focus on sub aspects of globalization. Economic aspects of globalization are believed to have an especially strong influence on the size of government and welfare state activities. However, globalization is a multi-faceted concept that cannot be captured by single economic indicators such as trade-openness or foreign direct investment. For this reason, the KOF index of globalization was introduced (KOF means “Konjunkturforschungsstelle” - Swiss Economic Institute).

\footnotetext{
${ }^{1}$ See Dreher and Gaston (2008), Bergh and Nilsson (2010), Anwar (2010) and Hellier and Chusseau (2010) on the influence of globalization on income and wage inequality and Bjørnskov (2009) on the influence of globalization on human rights.
} 
In this paper, we reconsider the globalization-welfare state nexus empirically. We employ data compiled by the Penn World Tables on the government sector size and the KOF indices of globalization. The sample covers 186 countries over the 1970-2004 period. Using this large dataset, we deal with three issues: (1) whether overall globalization influences the size of government, (2) whether different aspects of globalization have different effects on the size of government, and (3) whether potential globalization-induced effects on the size of government differ in democracies and autocracies, OECD and non-OECD countries, in high and low income countries and before and after the end of the Cold War in 1990. The results show that globalization had a positive influence on government sector size around the world. Social globalization, in particular, had a positive influence. Globalization-induced effects were stronger in OECD countries. Overall globalization and economic globalization reduced the relative price of government expenditures. These findings suggest that globalization does not jeopardize the welfare state at all.

The paper is organized as follows: section 2 presents the background on the two competing hypotheses describing the globalization-welfare state nexus and discusses the related empirical literature. Section 3 presents the data and specifies the empirical model. Section 4 reports and discusses the estimation results, and investigates their robustness. Section 5 concludes.

\section{The globalization welfare-state nexus: competing hypotheses and related empirical evidence}

\subsection{Competing hypotheses}

Trade openness and financial liberalization are believed to increase competition between national governments. In the course of globalization, national governments interact strategically with 
other governments to attract firms, investors and highly-skilled labor. ${ }^{2}$ Globalization thus restricts national fiscal autonomy, i.e. government spending, budget composition and tax policy.

The main prediction of the efficiency hypothesis is that globalization reduces the size of government: lower taxes, and lower government expenditures imply a retrenchment of the welfare state. Global economic integration results in an impressive growth of economic mobility and erodes the national autonomy of tax policy in developed countries, since it induces tax avoidance for investors and firms. Fiscal consequences of globalization in large countries might be very similar to those already experienced earlier in small open economies (Hines and Summers 2009). Globalization is expected to render all countries smaller. Small open economies face greater international competition than large countries and therefore rely much less on taxes from capital income and corporations. The tax competition literature therefore often predicts a global tax race to the bottom (e.g. Bretschger and Hettich 2002, Devereux et al. 2008). ${ }^{3}$

In a nutshell, the efficiency hypothesis suggests two trends: first, tax competition puts a downward pressure on tax rates on mobile factors, and second, governments have to reduce public spending, especially the social welfare state expenditures due to this tightened budget constraint. The concept is also called disciplining hypothesis, since depending on the point of view, either the efficiency of benevolent governments is reduced or egoistic governments are disciplined (Ursprung 2008).

While the "...efficiency effect captures the influence of globalisation on the supply side of the political market" (Schulze and Ursprung 1999: 300), it neglects its demand side. The compensation hypothesis (or embedded liberalism thesis) - introduced by Rodrik - makes up for this absence. Rodrik's view on the globalization-welfare state nexus is based on two observable

\footnotetext{
${ }^{2}$ Harms and Ursprung (2002) show that multinational enterprises are attracted by countries in which civil and political freedom is respected.

${ }^{3}$ See Lai (2010) on the political economy of capital market integration and tax competition. Patriotism may prevent a race to the bottom in tax competition because it generates a base of loyal citizens that makes the tax base less elastic with respect to tax rate changes and thus keeps taxes high. In OECD countries, patriotism indeed had a positive influence on tax burden (Qari et al. 2011).
} 
trends: the rising trade openness of Western Europe and the US since the 1950s on the one hand and the growth of governments (especially in social insurance programs) in particular in small open economies on the other hand (Rodrik 1997a, 2007). Rodrik (1998) shows that the scope of government in the most open economies is larger than in economies that are less integrated in the world market. The positive relationship between globalization and the size of government is no coincidence because growing internationalization yields a higher demand for social stability. Governments thus increase social welfare expenditures (Rodrik 1998). The reason is that international trade and financial integration lead to an increase in external risk. For example, fluctuations in trade and finance, and specialization in production give rise to uncertainty and income volatility. People therefore experience instability and employment fluctuations. Some people gain while others lose. This redistribution generates a higher demand for social insurance and compensation for the losers of globalization by means of unemployment insurance, benefit payments, etc. (Kim 2009: 211-212, Rodrik 1998: 998-999). Politicians satisfy their citizens' (and therefore also their voters') demand for higher social welfare expenditures to become reelected (Dreher et al. 2008b, Ursprung 2008).

To be sure, both, the efficiency and the compensation hypothesis imply that governments use fiscal and social policies to react to globalization. Governments may also use industrial policies such as (de)regulating labor and product markets or privatize state owned companies to react to globalization. Industrial policies are however not associated with the pure efficiency and compensation hypotheses. We will briefly discuss globalization-induced effects on labor market institutions and product markets in the conclusion.

Although the efficiency and the compensation hypotheses appear to contradict each other, it is not necessarily correct that only one of them applies. Globalization could evoke a reduction in tax revenues as proposed by the efficiency hypothesis. Yet, the conclusion of a welfare state retrenchment is not necessarily correct. Social spending might nonetheless rise due to the higher 
demand for social insurance as proposed by the compensation hypothesis (Rodrik 1997a). Lower revenues and higher expenditures could give rise to serious governance problems. Hines and Summers (2009: 2) arrive at the following conclusion: "One of the potential challenges for governments that are eager to maintain and possibly strengthen their spending programs is that the same forces that are responsible for recent economic changes might also raise the cost of financing government programs with certain types of taxes."

Another interpretation of a coexistence of the two effects is the following: the efficiency effect is in fact reducing the scope of government, while the compensation effect is counteracting by raising it. The question consequently should rather be to which degree these two effects offset each other than which of the hypotheses is true (Schulze and Ursprung 1999). From a theoretical point of view, we cannot predict which effect dominates and which amount of total effect remains. This certainly calls for an empirical analysis.

\subsection{Related empirical literature}

The empirical evidence on the globalization-welfare-state nexus is mixed. Scholars have used several variables to measure the size of government and globalization. Size of government has been measured, for example, by tax rates, overall revenues including tax income and contributions to the social security system, overall government expenditures and social expenditures. Globalization has been measured, for example, by trade openness, foreign direct investment, capital account restrictions and globalization indices. The studies also cover different countries and consider different time periods. The variety of measures, countries included and time periods considered appears to be an important reason for the mixed empirical evidence.

The first-generation literature of the globalization-welfare state nexus has appeared in the 1990s and mainly investigated the net effect of globalization on the welfare state using aggregated data. The results have been ambiguous. The second-generation literature adopts 
improved empirical techniques in order to handle the analysis of this complex topic and to receive more convincing results. Scholars use more disaggregated data and new proxies for the size of the welfare state and for globalization. But still no definite consensus about the relation of globalization and the size of the welfare state is reached. For encompassing surveys of the literature see, for example, Schulze and Ursprung (1999), Ursprung (2008) and Gemmell et al. $(2008){ }^{4}$

Among the most prominent studies supporting the compensation hypothesis are Rodrik (1998) and Cameron (1978). Rodrik (1998) employs a three and five year average of real government consumption as dependent variable and lagged trade openness (import plus export as a share of GDP averaged over the prior decade) as a measure for globalization. The results suggest a positive and highly significant influence of trade openness on government consumption for 125 countries over the 1985-1989 period and for 103 countries over the 19901992 period. Cameron (1978) already explored five possible reasons for the expansion of the public economy in 18 industrialized countries from 1960 to 1975, such as the higher trade dependence to other countries. He uses imports and exports as a share of GDP for measuring openness and total public revenues (taxes, contributions to social insurance etc.) as a share of GDP for measuring the public sector size and finds that nations "... with open economies were far more likely to experience an increase in the scope of public funding than were nations with relatively closed economies..." (Cameron 1978: 1253). The results by Vaubel $(2000,2005)$ also report a positive relationship between globalization and social expenditures.

The positive influence of globalization on social expenditures has been shown to depend on political-economic determinants. In OECD countries, for example, the increase in public spending appears to be weaker, the higher the number of veto players (Ha 2008). Leftwing

\footnotetext{
${ }^{4}$ On the relationship between globalization and economic growth see, for example, Dreher (2006b). A related strand of the literature investigates how globalization influences labor market performance and labor market institutions. See Koskela and Schöb (2010) on trade and outsourcing, Gaston and Nelson (2004) and Potrafke (2010) on globalization and labor market institutions, on trade and unemployment Yotov (2011).
} 
governments tended to spend more on social welfare than rightwing governments when globalization was proceeding rapidly. When globalization was proceeding moderately, however, government ideology did not influence social expenditures (Potrafke 2009).

Most previous studies concentrate on OECD countries. For Latin American countries, the results by Avelino et al. (2005), for example, suggest that (1) trade openness expands social spending, (2) financial openness has no significant influence on social expenditures and (3) democratic regimes spend more on welfare state programs than authoritarian regimes. In Western Europe, globalization as measured by the KOF index of globalization had a positive influence on social expenditures over the 1990-2006 period, whereas it had a negative influence on social expenditures in Eastern Europe (Leibrecht et al. 2011).

Other studies support the efficiency hypothesis, find evidence for a coexistence of the compensation as well as the efficiency effect, give contradicting results or state that there is no significant influence of globalization on the welfare state at all (e.g., Dreher 2006a). Rodrik (1997b), for example, employs annual panel data from OECD countries over the 1966-1991 period and finds a negative correlation between trade openness (lagged) and social spending as well as to government consumption. His results also suggest that in countries and periods with totally free capital accounts, openness has a considerably higher negative influence on social spending and government consumption than in countries with capital restrictions. Bretschger and Hettich (2002), for example, analyze 14 OECD countries from 1967 to 1996 and conclude that the efficiency hypothesis is able to explain taxation patterns, while the compensation hypothesis is able to explain government expenditures patterns. Busemeyer (2009) finds a negative association between trade-openness and public spending in OECD countries.

Garrett and Mitchell (2001) use data from 18 OECD countries over the 1961-1993 period and find that trade openness negatively influences government spending, but not government consumption and social security transfers. Kittel and Winner (2005) re-estimate the model by 
Garrett and Mitchell (2001) using more sophisticated empirical techniques and find neither evidence for the efficiency nor for the compensation hypothesis. Instead, they conclude that public expenditures are predominately influenced by domestic economic and demographic variables such as unemployment and the dependency ratio. Recent empirical evidence also does not suggest a global tax race to the bottom (Plümper et al. 2009).

Globalization may not have influenced overall government expenditures because the compensation and the efficiency effect neutralize each other. Globalization, however, could influence the composition of public expenditures. Dreher et al. (2008b) investigate whether globalization influenced budget composition and employ two datasets - one containing 60 countries over the 1971-2001 period and another one covering 10 OECD countries over the 1991-2000 period. Dreher et al. (2008b) apply four different proxies for globalization: the sum of imports and exports, the sum of in- and outflows of foreign direct investment (both of them as a share of GDP), restrictions on capital account transactions and the KOF globalization index. Their results suggest that globalization has not influenced budget composition.

The empirical studies on the globalization-welfare state nexus show that so far "a robust impact of globalization on government expenditures does not appear to exist." (Dreher et al. 2008b: 264). We re-examine the globalization-welfare state nexus employing a larger dataset than used before.

\section{Data and empirical strategy}

\subsection{Data}

We employ the 2009 KOF globalization indices that are available for the 1970-2006 period and annual panel data from the Penn World Tables 6.2 (Heston et al. 2006) containing the dependent variable and some of the control variables that are available for the 1950-2004 period. The 
combined dataset includes data from 186 countries over the 1970-2004 period. ${ }^{5}$ Tables A1 and A2 show the list of included countries and descriptive statistics of the variables. The annual panel dataset is unbalanced, since the variables have missing values for some countries or years. In the base-line model, we employ five year averages of the variables to exploit variation across countries and time. When all observations in a five year interval are missing, we assign the five year average also as missing. When one, two, three or four observations are present, we use the average of the available data in every five year time interval.

\section{The size of government measure}

We use the government share as a percentage of real GDP per capita (CG) compiled by the Penn World Tables as the measure of government size. The most important reason for our choice is the large sample. The disadvantage is that CG measure does not include transfer payments. We thus acknowledge that by using the CG measure one implicitly focuses on how globalization influences the size of government and not on globalization-induced effects on welfare state activities. Higher social expenditures are usually associated with a larger size of government as measured by our CG indicator.

Data on social expenditures are not available for such a large sample. Rodrik (1998: 1012) argues that social welfare spending is appropriate only for advanced countries, since less developed countries often do not have “...the establishment of a safety net." They rather "... rely on a broader set of instrumentalities." These instrumentalities may therefore be captured better by a widespread government measure such as the government share of real GDP per capita.

Figure 1 shows that the government share as a percentage of real GDP per capita increased on average from $19.51 \%$ in 1970 to $24.36 \%$ in 2003 . The size of the government sector thus rather increased than decreased. Growth of the government sector was the strongest in the 1970s

\footnotetext{
${ }^{5}$ The dependent variable has many missing values in for the year 2004 . We therefore do not consider the year 2004 in Figure 1.
} 
and the beginning of the 1980s. From 1987 to 1989 the government share significantly decreased. From 1991 on, government grew much more slowly and in some years government size even slightly decreased.

\section{The KOF index of globalization}

The 2009 KOF index assembles 24 variables to an overall index and three sub-indices covering the economic, social and political dimensions of globalization. The 24 variables are aggregated in six groups: (1) actual flows of trade, investment and income payments to foreign nationals, (2) restrictions on international trade and capital account, (3) data on personal contact with people living in foreign countries, (4) data on information flows, (5) data on international cultural integration, and (6) data on international political integration.

The first two groups form the economic globalization sub-index. The following three groups form the social globalization sub-index and the last group the political globalization subindex. All of them together define the overall index. Table A3 lists all the variables and weights in detail. The overall index is available for 158 countries, the political globalization sub-index for 207 countries, the economic globalization sub-index for 139 countries and the social globalization sub-index for 161 countries. The original KOF index was published in 2002 (see Dreher et al. 2008a for details).

The overall index and the sub indices assume values scaled from 1 (minimum of globalization) to 100 (maximum of globalization). Globalization was high in countries such as the Netherlands (82.7), Luxembourg (82.7) and Canada (80.4) and quite low in countries such as Rwanda (22.1), Congo (23.4) and Nepal (25.2).

Figure 2 illustrates the development of the different KOF globalization indices over the 1970-2004 period. The indices substantially increased from about 38 to 61 (only the political sub-index starts at about 34 and the social one stops at 58). While the overall KOF index and the 
sub indices on economic and social globalization rose quite monotonically, the sub index on political globalization shows more fluctuation. This sub-index decreased in the end of the 1980s and increased steeper than the others in the beginning of the 1990s. An explanation for this pattern is the influence of the Cold War that restricted global political integration. After 1990 political cooperation significantly increased.

\subsection{Correlation between globalization and size of government}

To illustrate the association between globalization and size of government around the world, we present correlations between the size of government measure and the KOF globalization indices (five year averages). Figure 3 suggests that overall globalization was not associated with size of government around the world. The correlation coefficient between the overall KOF index of globalization and size of government is -0.05 . In a similar vein, the correlation between the KOF index of economic globalization and size of government is 0.03 (Figure 4) and 0.01 between the KOF index of social globalization and size of government (Figure 5). By contrast, political globalization is somewhat negatively associated with size of government: the correlation coefficient between the KOF index of political globalization and size of government is -0.30 (Figure 6). The correlations do, however, not take into account the development over time, individual country effects and other covariates, which we consider in the econometric panel data model. 


\subsection{The empirical model}

The base-line econometric panel data model has the following form:

$\log$ Size of government $\mathrm{it}_{\mathrm{i}}=\alpha_{\mathrm{j}} \log$ Globalization $_{\mathrm{ijt}}+\Sigma_{\mathrm{k}} \zeta_{\mathrm{k}} \log \mathrm{x}_{\mathrm{ikt}}+\mu_{\mathrm{i}}+\lambda_{\mathrm{t}}+u_{\mathrm{it}}$

$$
\text { with } \mathrm{i}=1, \ldots, 186 ; \mathrm{j}=1, . ., 4 ; \mathrm{k}=1, \ldots, 3 ; \mathrm{t}=1, \ldots, 7
$$

The dependent variable log Size of government $t_{i t}$ is the logarithm of government expenditures as a share of GDP in country $i$ in the five year period t. Log Globalization $_{i t j}$ denotes the logarithm of the $\mathrm{j}^{\text {th }}$ dimension of the KOF globalization index (overall, economic, social, and political dimension). The vector $\log \boldsymbol{x}_{i k t}$ contains the logarithms of our economic control variables. Following Dreher et al. (2008b), Alesina and Wacziarg (1998) and Potrafke (2009) we include real GDP per capita, the age dependency ratio (ratio of people younger than 15 and older than 65 to the working-age population of the age $15-64$ in \%) and total population (in thousands). ${ }^{6}$ Real GDP per capita captures the general economic situation. The dependency ratio controls for the age structure and the demographic development. We include total population as a measure for country size following Alesina and Wacziarg (1998), because a smaller population is likely to have a larger share of government in GDP. $\mu_{i}$ describes a fixed country effect, $\lambda_{t}$ describes a fixed period effect and $u_{i t}$ is an error term. In the base-line model, we use logarithms of the dependent and explanatory variables to better account for outliers and smooth the distributions of the variables and also to interpret the coefficients of the explanatory variables as elasticities. In the robustness tests section, we discuss results using levels of the five year averages instead of logarithms and results with annual data in growth rates. ${ }^{7}$ We estimate the model with feasible

\footnotetext{
${ }^{6}$ It is important to note that we cannot include a government ideology index because there is no government ideology index available for the entire sample. Reliable government ideology indices are available for OECD countries and only some developing countries. See, for example, Bjørnskov (2005, 2008) and Potrafke (2009). ${ }^{7}$ The results are available in the appendix
} 
generalized least squares and with heteroskedastic and autocorrelation consistent (HAC) NeweyWest type standard errors (Newey and West 1987, Stock and Watson 2008).

\section{Results}

\subsection{Basic results}

Table 1 shows our base-line regression results. Column (1) shows the results when only the overall KOF index of globalization is included to illustrate that the inferences regarding globalization are not driven by including/excluding the economic control variables. Per capita income is statistically significant at the $5 \%$ level in columns (3) and (4), yet lacks statistical significance at conventional levels in columns (2) and (5) and has in these estimates a negative sign. The numerical meaning of the estimated coefficients is that when GDP per capita increased by $1 \%$, government expenditures as a share of GDP decreased by about $0.13 \%$. On the one hand, the influence of GDP per capita on government sector size is purely mechanical because when GDP increases, the government sector size ceteris paribus decreases. On the other hand, the finding suggests that governments tend to react to recessions by somewhat raising expenditures. The dependency ratio and total population do not turn out to be statistically significant. The null hypotheses of F-tests that the fixed country effects and the fixed period effects do not turn out to be jointly significant can be rejected at the $1 \%$ level in each case.

Most importantly, the results reported in Table 1 show that globalization has had a positive influence on government sector size around the world. The coefficients of the overall KOF index of globalization have positive signs and are statistically significant at the $5 \%$ level in columns (1) and (2). The numerical meaning of the estimated coefficients is that when the overall KOF index of globalization increased by $1 \%$, government expenditures as a share of GDP increased by about $0.3 \%$; that is an increase of the overall KOF index of globalization by one standard deviation (16 points on a scale from 1 to 100 ) increases government expenditures as 
a share of GDP by about two percentage points; for example, from $23 \%$ (mean value) to about $25 \%$. The globalization-induced effect on government sector size is driven by social globalization: the coefficient of the KOF index of social globalization is statistically significant at the $1 \%$ level (column 4) and indicates that government expenditures as a share of GDP increased by about $0.28 \%$ when the KOF index of social globalization increased by $1 \%$. By contrast, the coefficient of the KOF index of economic globalization does not turn out to be statistically significant (column 3). The coefficient of the KOF index of political globalization is statistically significant at the $10 \%$ level and indicates that government expenditures as a share of GDP increased by about $0.10 \%$ when the KOF index of political globalization increased by $1 \%$. (column 5). The results thus do not support the conjecture that economic globalization has generated a higher demand for social insurance and governments compensate the losers of globalization (Rodrik). The positive influence of social globalization on the size of government rather suggests a catch-up effect: the more people have been globally interconnected and observed government sector size in other countries, the more government expenditures they have demanded in their home countries.

\subsection{Results for sub samples}

We have tested the robustness of the results in several ways. First, we have tested whether the results differ in sub samples. We have therefore investigated globalization-induced effects before and after the end of the Cold War in 1990, in democracies and autocracies, in OECD and nonOECD countries, and in high and low income countries. To do so, we have included interaction terms and calculated marginal effects on how globalization influences size of government before and after the end of the Cold War in 1990 and given that a country was a high or low income country, democratic or autocratic, OECD or no OECD member country. 
We have tested whether the results are sensitive to the time period considered. In particular, to the 1970-1989 period, which was dominated by the Cold War, and the 1990-2004 period after the end of the Cold War. In the 1990-2004 period, Europe experienced a recession caused by sharply increasing interest rates. The economic circumstances and the Gulf War in 1991 led to instability of the world market. Economic growth was strong over the 1970-1989 period and much slower or even negative over the 1990-2004 period. ${ }^{8}$ Since circumstances in these two periods were different we have examined potential globalization-induced effects on the size of government in both periods separately.

To address this issue, we have included a dummy variable that takes on the value 1 for the 1970-1989 period and 0 for the 1990-2004 period. Moreover, we have included the interaction of the globalization variables and this Cold War dummy to identify potential differences between globalization-induced effects on the size of government in both periods. We have normalized (mean zero, variance one) the globalization variables and the Cold War dummy before interacting (and will also do so with other variables to interact with globalization - see below).

As can be seen from Table 2, the coefficients of the overall KOF index of globalization and the KOF index of social globalization still have a positive sign and are statistically significant. The Cold War dummy indicates a negative and statistically significant effect on government sector size. The marginal effects of the globalization variables have to be interpreted conditionally on the interaction with the Cold War dummy (see Friedrich 1982). In principle, there are two sensible ways to evaluate the marginal effects. We follow Dreher and Gassebner (2011), evaluating the marginal effects at the minimum as well as the maximum of the interacted variable, i.e., before or after 1990 (Table 3). Using this method one can distinguish between the impacts of globalization on size of government before and after 1990. If one chooses to evaluate

\footnotetext{
${ }^{8}$ The role of international organizations in the world economy has also changed after the end of the Cold War (e.g., Moser and Sturm 2011).
} 
the marginal effects at the average level of the Cold War dummy, the numerical meaning and the statistical significance of these average effects corresponds to the coefficients and t-statistics of the globalization variable. Table 3 indicates that there were significant marginal effects before and after 1990.

The marginal effects presented in Table 3 can be interpreted as follows: over the 19701989 period, an increase in the overall KOF index of globalization by $1 \%$ increased government expenditures as a share of GDP by about $0.1 \%$. But also over the $1990-2004$ period, an increase in the overall KOF index of globalization by $1 \%$ increased government expenditures as a share of GDP by about $0.1 \%$. The influence of social globalization was slightly larger over the 1990 2004 period than the $1970-1989$ period: over the $1970-1989$ period, an increase in the KOF index of social globalization by $1 \%$ increased government expenditures as a share of GDP by about $0.17 \%$; while over the $1990-2004$ period, an increase in the KOF index of social globalization by $1 \%$ increased government expenditures as a share of GDP by about $0.15 \%$. Political globalization had a weak effect on size of government over the 1970-1989 period, but no effect after 1990: the marginal effect of the KOF index of political globalization is statistically significant at the 10\% level for the 1970-1989 period.

We have tested whether inferences are sensitive to political institutions. To deal with this issue, we have used the Democracy-Dictatorship variables by Cheibub et al. (2010). The Democracy-Dictatorship dummy variable distinguishes between regimes in which executive and legislative offices are allocated in contested elections and those regimes in which this is not the case. The variable assumes the value one for democracies and zero otherwise. ${ }^{9}$ We have included five year averages of the Democracy-Dictatorship variable and interacted them with the globalization variables. Table 4 shows the regression results and Table 5 shows the marginal

\footnotetext{
${ }^{9}$ See Cheibub et al. (2010) for a more encompassing discussion on classifying democracies and dictatorships. The more traditional measures of democracy are the POLITY IV and the Freedom House indices. These indices have, however, been criticized on several grounds (Munk and Verkuilen 2002, Vreeland 2008, Cheibub et al. 2010).
} 
effects: globalization-induced effects (overall globalization and social globalization) on the size of government did not differ in democracies versus dictatorships.

Distinguishing between OECD and non-OECD countries shows, in contrast to the results discussed above, that globalization had a stronger influence on the size of government in OECD countries than in non-OECD countries (Tables 6 and 7). The results in Table 6 show that the coefficient of the overall KOF index of globalization has a positive sign and is statistically significant at the 5\% level in columns (1) and (2). The coefficient of the KOF index of social globalization is statistically significant at the $1 \%$ level (column 4). The coefficient of the KOF index of political globalization is statistically significant at the $5 \%$ level (column 5). The marginal effects presented in Table 7 show that an increase in the overall KOF index of globalization by $1 \%$ increased government expenditures as a share of GDP by about $0.17 \%$ in OECD countries but only by about $0.10 \%$ in Non-OECD countries. An increase in the KOF index of social globalization by $1 \%$ increased government expenditures as a share of GDP by about $0.19 \%$ in OECD countries, and about $0.14 \%$ in Non-OECD countries. An increase in the KOF index of political globalization by $1 \%$ increased government expenditures as a share of GDP by about $0.29 \%$ in OECD countries, but only by about $0.08 \%$ in Non-OECD countries. The marginal effects with respect to the KOF index of economic globalization do not turn out to be statistically significant. The globalization-induced increase in the size of government in OECD countries corresponds with the related studies that have reported evidence for the compensation hypothesis especially in OECD countries. We propose that this effect is because, first, OECD countries possess well-established economic and political institutions to better react to any exogenous shocks. For example, tax bases are well-established (e.g., Aidt and Jensen 2009). Freedom of the press and media coverage are encompassing and ensure that the population is informed and observes government sector size in other countries. Second, the OECD regularly keeps track of the economic policy of its member states. It is conceivable that this monitoring 
induces the member states to keep in line with the generally acknowledged patterns of policy response recommended by the OECD.

We have tested whether inferences are sensitive to real GDP per capita. The results by Rudra (2002) suggest that weak labor power combined with trade openness has a negative effect on social expenditures in LDCs. Whereas workers of developed countries have a strong organization helping to accomplish their benefits in form of higher welfare spending. Hence, the positive effect in developed countries could be offset by the negative effect in less developed ones. To deal with this issue we have interacted the globalization variables (logs) with real GDP per capita $(\operatorname{logs})$. The results in Table 8 show that overall, social and political globalization had a positive influence on the size of government at average income levels. The marginal effects in Table 9 show that the positive effect appears to be driven by low income countries: the marginal effects are only statistically significant at minimum income levels and do not turn out to be statistically significant at maximum income levels at conventional levels. It is important to note, however, that the size of the marginal effects at minimum income levels which are statistically significant (overall globalization and social globalization) hardly differs from the size of the marginal effects at maximum income levels. In contrast, to the OECD dummy variable, the Cold War dummy variable and the democracy variable, real GDP per capita is a continuous variable and Table 9 shows marginal effects evaluated at the minimum and maximum level of real GDP per capita. Distinguishing between real GDP per capita differs from distinguishing between OECD and Non-OECD members because some high income countries and Non-OECD members such as Israel and Singapore are highly globalized but have a rather small size of government, and also some low income countries and Non-OECD members such as Maldives, Lesotho and Mauritania are fairly high globalized and also have a quite big size of government. ${ }^{10}$

\footnotetext{
${ }^{10}$ Israel became an OECD member state on September 7, 2010.
} 
In the base-line model, we use logarithms of the dependent and explanatory variables to better account for outliers and smooth the distributions of the variables. For robustness tests, we have estimated the model in levels of the five year averages and have not used logarithms. Taking logs transforms the model in a non-linear way. The results using the variables in levels show that only social globalization has a positive influence on the size of government. The overall KOF index of globalization and the sub indices of economic and political globalization do not turn out to be statistically significant. Using levels instead of logs of levels does not change the inference that globalization-induced effects (1) hardly differ before and after 1990, (2) between democracies and dictatorships and (3) that globalization had a positive influence on size of government in OECD countries. The results in levels do however not indicate any differences in globalization-induced effects between high and low income countries. The results thus show that accounting for outliers and smoothing the distributions of the variables renders overall globalization to have a significantly positive influence on the size of government. The positive influence of social globalization and globalization in general in OECD countries on the size of government is shown to be robust.

In a similar vein, we have estimated the model with annual data in growth rates. The disadvantage of a model with annual data in growth rates is that it ignores variation in the level of government size across countries. In any event, the results using annual data in growth rates show that the globalization indices had a weakly positive influence on size of government or do not turn out to be statistically significant. We therefore conclude that globalization did not negatively influence the size of government.

An alternative test for globalization-induced effects on the size of government is to investigate how globalization influences the relative price of government expenditures (costs). We have therefore used the price level of government divided by total prices as dependent variable (the data are also taken from the Penn World Tables). Following our previous 
specification we have chosen five year averages in logs. The results in Table 10 show that overall globalization and economic globalization had a negative influence on the relative price of government size. The coefficients of the overall KOF index of globalization and the sub indices on economic globalization (columns 2 and 3) are statistically significant at the $5 \%$ level and indicate that the relative price of government size decreased by about $0.23 \%$ or $0.12 \%$ when the overall KOF index and the KOF index of economic globalization increased by $1 \%$. The KOF indices on social and political globalization do not turn out to be statistically significant. These findings show that costs of government expenditures decreased in the course of economic globalization. Expanding government size thus became less costly and easier to achieve. ${ }^{11}$

We have also examined whether globalization-induced effects on the relative price of government expenditures differed before and after the end of the Cold War in 1990, in democracies and autocracies, in OECD and non-OECD countries, and in high and low income countries. The results show that the negative influence of globalization on the relative price of government expenditures is driven by dictatorships, non-OECD and low income countries and was stronger over the 1970-1989 period compared to the 1990-2004 period. The negative influence of globalization on the price of government expenditures vanishes when we estimate the model in levels instead of logs of levels. ${ }^{12}$

\section{Conclusion}

We have re-examined the globalization-welfare state nexus in a large panel of 186 countries over the 1970-2004 period: the results show that globalization has had a positive influence on government sector size around the world. Social globalization has had an especially strong effect. Globalization-induced effects were stronger in OECD countries. Overall globalization and

\footnotetext{
${ }^{11}$ To be sure, the relative price of government expenditures does not measure traditional "public sector efficiency" (e.g., Afonso et al. 2005, Adam et al. 2011a,, 2011b). Future research may well investigate how globalization has influenced public sector efficiency.

${ }^{12}$ The results are available in the appendix.
} 
economic globalization reduced the relative price of government expenditures. These findings suggest that globalization does not induce a collapse of the welfare state at all.

The results help to explain the mixed evidence of previous studies. For example, government has indeed been larger (and social expenditures higher) in OECD countries when globalization was proceeding rapidly. The different aspects of globalization also have had different effects on the size of government. Some scholars believe that economic globalization tends to decrease the size of government and social expenditures. Our results show that economic globalization did not have these alleged effects.

To measure government size, we have chosen the government share of real per capita GDP (CG) compiled by the Penn World Tables. The advantage of this measure is that it is available for a large sample of countries. The disadvantage is that it does not include transfer payments. We thus acknowledge that by using the CG measure one implicitly focuses on how globalization influences the size of government and not on globalization-induced effects on welfare state activities. Notice, however, that the CG measure includes the cost of public administration that is necessary for a well functioning welfare state. Higher social expenditures are usually associated with a larger size of government as measured by our CG indicator. Arguably more important is that the CG measure does not include regulation policies. In East Asia, for example, social programs are provided as a combination of regulated markets, a systematic approach to international integration, and practices of enterprises such as lifetime employment and social benefits for company employees (Rodrik 2007). It is conceivable that governments not greatly increase social expenditures when globalization is proceeding rapidly, but instead regulate the labor market or particular industries in such a way as to prevent high unemployment. ${ }^{13}$ Empirical studies however show that globalization as measured by the KOF

\footnotetext{
${ }^{13}$ Boulhol's (2009) model suggests the opposite: increasing globalization will induce labor market deregulation.
} 
indices did not influence labor market institutions in OECD countries (Potrafke 2010) and around the world (Potrafke 2011).

We also acknowledge that the efficiency effect might neutralize the compensation effect “...implying that the marginal increase in political support deriving from extending the size and scope of compensation programs is offset by the marginal loss in political support associated with raising the requisite additional funds" (Dreher et al. 2008b: 284). Governments do not profit from raising or reducing welfare spending and consequently do not react to higher levels of global integration.

In any event, there is neither an objective foundation to fear that nation states will lose their fiscal autonomy and the welfare state collapses in the context of globalization. Nor is there any sign that governments need to compensate exposure to external risk by a drastic enhancement of welfare spending. 


\section{References}

Adam, A., Delis, M.D., \& Kammas, P. (2011a). Public sector efficiency: leveling the playing field between OECD countries. Public Choice 146, 163-183.

Adam, A., Delis, M.D., \& Kammas, P. (2011b). Are democratic governments more efficient? European Journal of Political Economy 27, 75-86.

Afonso, A., Schuknecht, L. \& Tanzi, V. (2005). Public sector efficiency: An international comparison. Public Choice 16, 362-394.

Aidt, T.S., \& Jensen, P.S. (2009). Tax structure, size of government, and the extension of the voting franchise in Western Europe, 1860-1938.

International Tax and Public Finance 16, 362-394.

Alesina, A., \& Wacziarg, R. (1998). Openness, country size and the government. Journal of Public Economics 69, 305-322.

Anwar, S. (2010). Wage inequality, increased competition and trade liberalization: short run versus long run. Review of International Economics 18, 574-581.

Avelino, G., Brown, D.S., \& Hunter, W. (2005). The effects of capital mobility, trade openness, and democracy on social spending in Latin America, 1980-1999.

American Journal of Political Science 49, 625-641.

Bergh, A., \& Nilsson, T. (2010). Do liberalization and globalization increase income inequality? European Journal of Political Economy 26, 488-505.

Bjørnskov, C. (2005). Does political ideology affect economic growth? Public Choice 123, 133-146.

Bjørnskov, C. (2008). The growth-inequality association: government ideology matters. Journal of Development Economics 87, 300-308.

Bjørnskov, C. (2009). On globalization and human rights: the importance of types of globalization. University of Aarhus, Working Paper.

Boulhol, H. (2009). Do capital markets and trade liberalization trigger labor market deregulation. Journal of International Economics 77, 223-233.

Bretschger, L. \& Hettich, F. (2002). Globalisation, capital mobility and tax competition: theory and evidence for OECD countries. European Journal of Political Economy $18,695-716$.

Busemeyer, M.R. (2009). From myth to reality: globalization and public spending in OECD countries revisited. European Journal of Political Research 48, 455-482. 
Cameron, D.R. (1978). The expansion of the public economy: A comparative analysis. American Political Science Review 72, 1243-1261.

Cheibub, J., Gandhi, J., \& Vreeland, J.R. (2010). Democracy and dictatorship revisited. Public Choice 143, 67-101.

Devereux, M.P, Lockwood, B., \& Redoano, M. (2008). Do countries compete over corporate tax rates? Journal of Public Economics 92, 1210-1235.

Dreher, A. (2006a). The influence of globalization on taxes and social policy: An empirical analysis for OECD countries.

European Journal of Political Economy 22, 179-201.

Dreher, A. (2006b). Does globalization affect growth? Empirical evidence from a new index. Applied Economics 38, 1091-1110.

Dreher, A., Gassebner, M. (2011). Greasing the wheels of entrepreneurship? The impact of regulations and corruption on firm entry. Public Choice, forthcoming.

Dreher, A., \& Gaston, N (2008). Has globalisation increased inequality? Review of International Economics 16, 516-536.

Dreher, A., Gaston, N. \& Martens, P. (2008a): Measuring globalisation - gauging its consequences, Berlin (Springer).

Dreher, A., Sturm, J.-E. \& Ursprung H. W. (2008b). The impact of globalization on the composition of government expenditures: Evidence from panel data. Public Choice 134, 263-292.

Friedrich, R.J. (1982). In defence of multiplicative terms in multiple regression equations. American Journal of Political Science 26, 797-833

Garrett, G. \& Mitchell, D. (2001). Globalization, government spending and taxation in the OECD. European Journal of Political Research 39, 145-177.

Gaston, N., \& Nelson, D. (2004). Structural change and the labor-market effects of globalization. Review of International Economics 12, 769-792.

Gemmell, N., Kneller R., \& Sanz I. (2008). Foreign investment, international trade and the size and structure of public expenditures.

European Journal of Political Economy 24, 151-171.

Ha, E. (2008). Globalization, veto players, and welfare spending. Comparative Political Studies 41, 783-813.

Harms, P., \& Ursprung, H.W. (2002). Do civil and political repression really boost foreign direct investments? Economic Inquiry 40, 651-663. 
Hellier, J., \& Chusseau, N. (2010). Globalization and the inequality-unemployment tradeoff. Review of International Economics 18, 1028-1045.

Heston, A., Summers, R., \& Aten B. (2006). Penn World Table Version 6.2. Center for International Comparisons of Production, Income and Prices at the University of Pennsylvania.

Hines, Jr.J.R., \& Summers, L.H. (2009). How globalization affects tax design. NBER Working Paper 14664, Cambridge.

Kim, T.K. (2009). Globalization and state-supported welfare. A test of the curve-linear hypothesis in OECD countries. International Social Work 52, 209-222.

Kittel, B., \& Winner, H. (2005). How reliable is pooled analysis in political economy? The globalization-welfare state nexus revisited. European Journal of Political Research, 44, 269-293.

Koskela, E., \& Schöb, R. (2010). Outsourcing of unionized firms and the impact of labor market policy reforms. Review of International Economics 18, 769-792.

Lai, Y.-B. (2010). The political economy of capital market integration and tax competition. European Journal of Political Economy 26, 475-487.

Leibrecht, M., Klien, M., \& Onaran, O. (2011). Globalization, welfare regimes and social protection expenditures in Western and Eastern European countries.

Public Choice, forthcoming.

Moser, C., \& Sturm, J.-E. (2011). Explaining IMF lending decisions after the Cold War. Review of International Organizations, forthcoming.

Munck, G., \& Verkuilen, J. (2002). Conceptualizing and measuring democracy: Evaluating alternative indices. Comparative Political Studies 55, 5-34.

Newey,W.K., \& West, K.D. (1987). A simple, positive semi-definite, heteroskedasticity and autocorrelation consistent covariance matrix. Econometrica 55, 703-708.

Plümper, T., Troeger, V. E., \& Winner, H. (2009). Why is there no race to the bottom in capital taxation? Tax competition among countries of unequal size, different levels of budget rigidities and heterogeneous fairness norms. International Studies Quarterly 53, 761-786.

Potrafke, N. (2009). Did globalization restrict partisan politics? An empirical evaluation of social expenditures in a panel of OECD countries. Public Choice 140, 105-124.

Potrafke, N. (2010). Labor market deregulation and globalization: Empirical evidence from OECD countries. Review of World Economics 146, 545-571. 
Potrafke, N. (2011). Globalization and labor market deregulation: International empirical evidence. Working paper, University of Konstanz.

Qari, S., Konrad, K.A., \& Geys, B. (2011). Patriotism, taxation and international mobility. Public Choice, forthcoming.

Rodrik, D. (1997a). Trade, social insurance, and the limits to globalization. NBER Working Paper 5905, Cambridge.

Rodrik, D. (1997b). Has globalisation gone too far? Institute for International Economics (Washington D.C.).

Rodrik, D. (1998). Why do more open Economies have bigger governments? Journal of Political Economy 106, 997-1032.

Rodrik, D. (2007): One economics, many recipes. Globalization, institutions, and economic growth, Princeton University Press (New Jersey).

Rudra N. (2002). Globalization and the decline of the welfare state in less-developed ountries. International Organization 56, 411-445.

Schulze, G.G., \& Ursprung, H.W. (1999). Globalisation of the economy and the nation state. World Economy 22, 295-352.

Stock, J.H., \& Watson, M.W. (2008). Heteroskedasticity-robust standard errors for fixed effect panel data regression. Econometrica 76, 155-174.

Ursprung, H. W. (2008): Globalization and the welfare state. In Durlauf, S. N., and Blume, L.E. (Eds.) The New Palgrave Dictionary of Economics. Second Edition. Palgrave Macmillan (Köln).

Vaubel, R. (2000). Internationaler politischer Wettbewerb: Eine europäische Wettbewerbsaufsicht für Regierungen und die empirische Evidenz. In Schenk, K.-E., Schmidtchen, D., Streit, M. E. and Vanberg,V. (Eds.) Jahrbuch für Neue Politische Ökonomie (pp.280-309). Tübingen: Mohr-Siebeck.

Vaubel, R. (2005). Sozialpolitische Konsequenzen der Globalisierung-Theorie und Empirie. In Freytag, A. (Ed.) Wirtschaftlicher Strukturwandel, nationale Wirtschaftspolitik und politische Rationalität (pp. 143-158). Köln: Kölner Universitätsverlag GmbH.

Vreeland, J.R. (2008). The effect of political regime on civil war: Unpacking anocracy. Journal of Conflict Resolution 52, 401-425.

Yotov, Y.V. (2010). Trade-induced unemployment: how much do we care? Review of International Economics 18, 972-989. 
Figure 1: Government expenditures as a share of GDP (CG measure). 186 countries. 1970-2003.

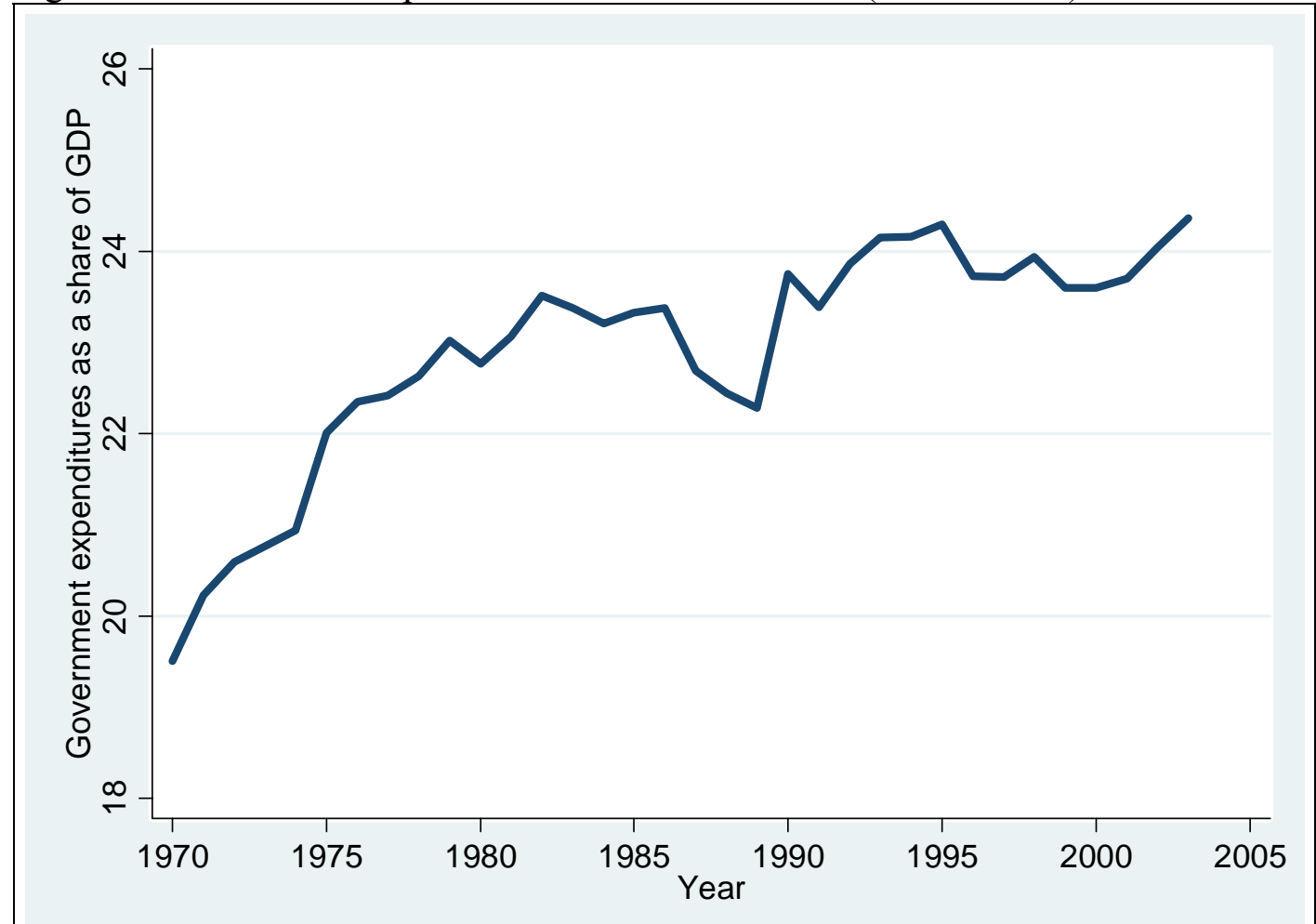

Source: Penn World Tables 6.2

Figure 2: KOF indices of globalization. 186 countries.1970-2004.

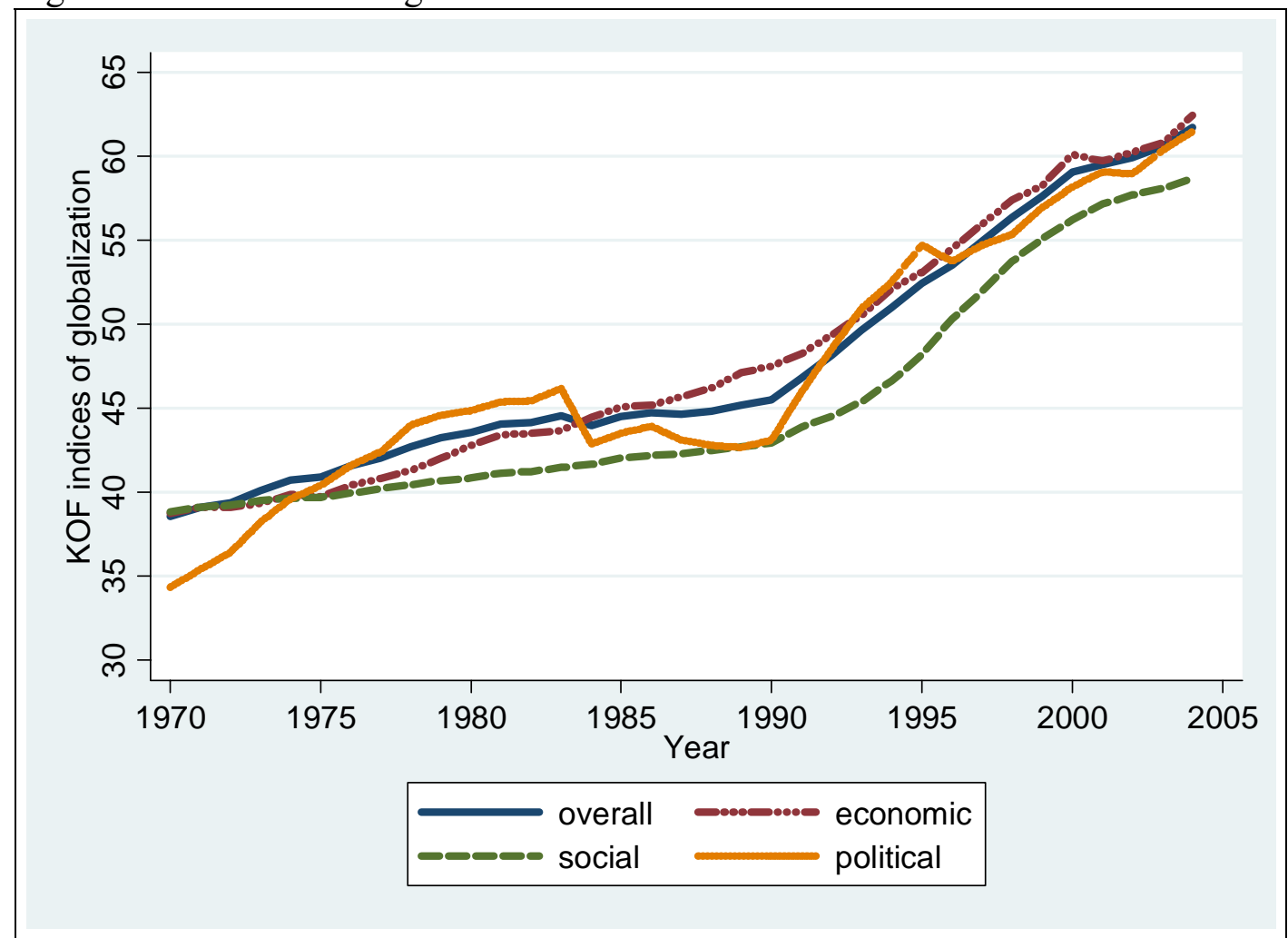

Source: Penn World Tables 6.2 and Dreher (2006) and Dreher et al. (2008a) 
Figure 3: Size of government and overall KOF index of globalization 1970-2004 (five year averages).

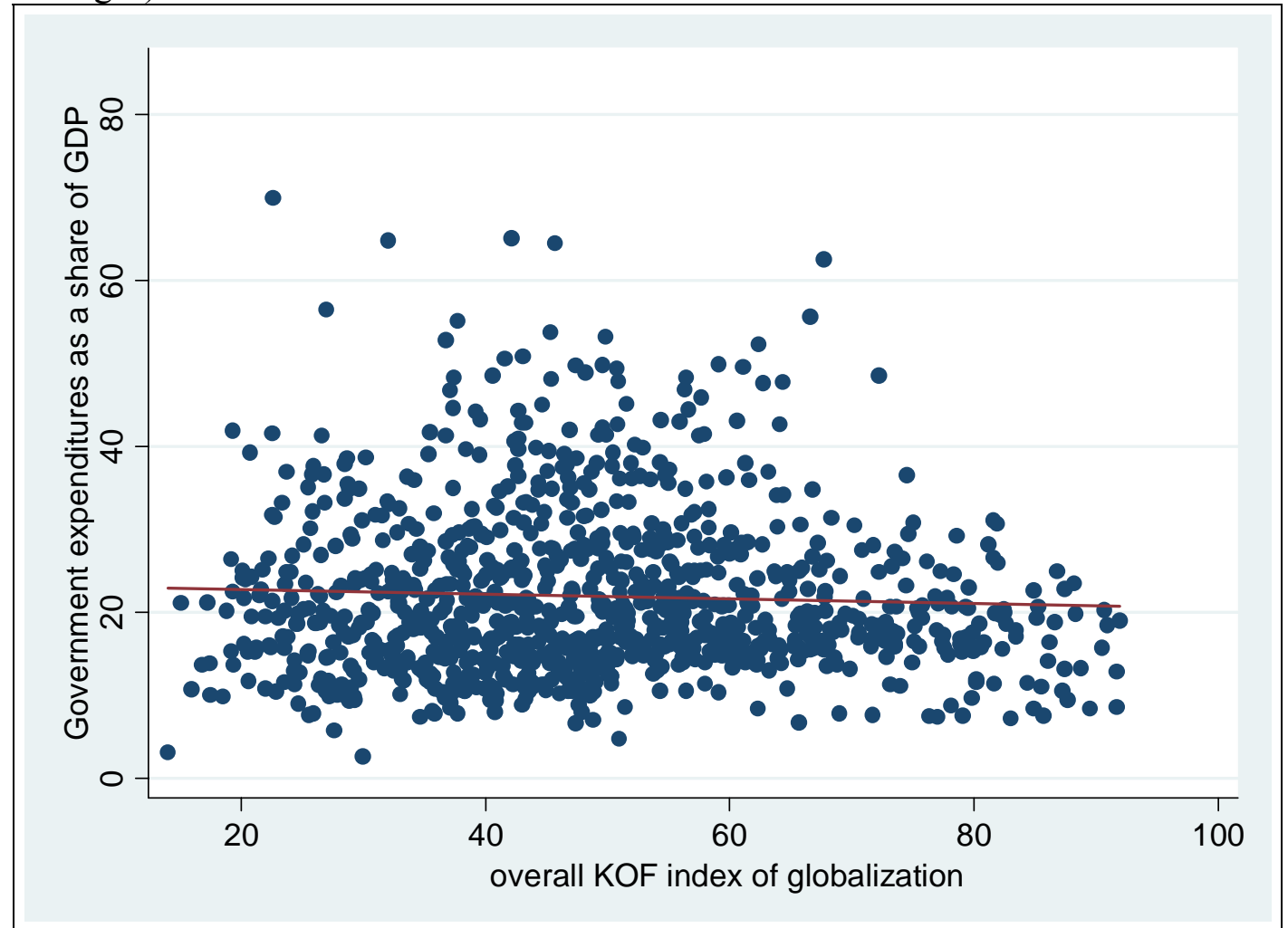

Correlation coefficient: -0.05. Source: Penn World Tables 6.2 and Dreher (2006) and Dreher et al. (2008a)

Figure 4: Size of government and KOF index of economic globalization 1970-2004 (five year averages).

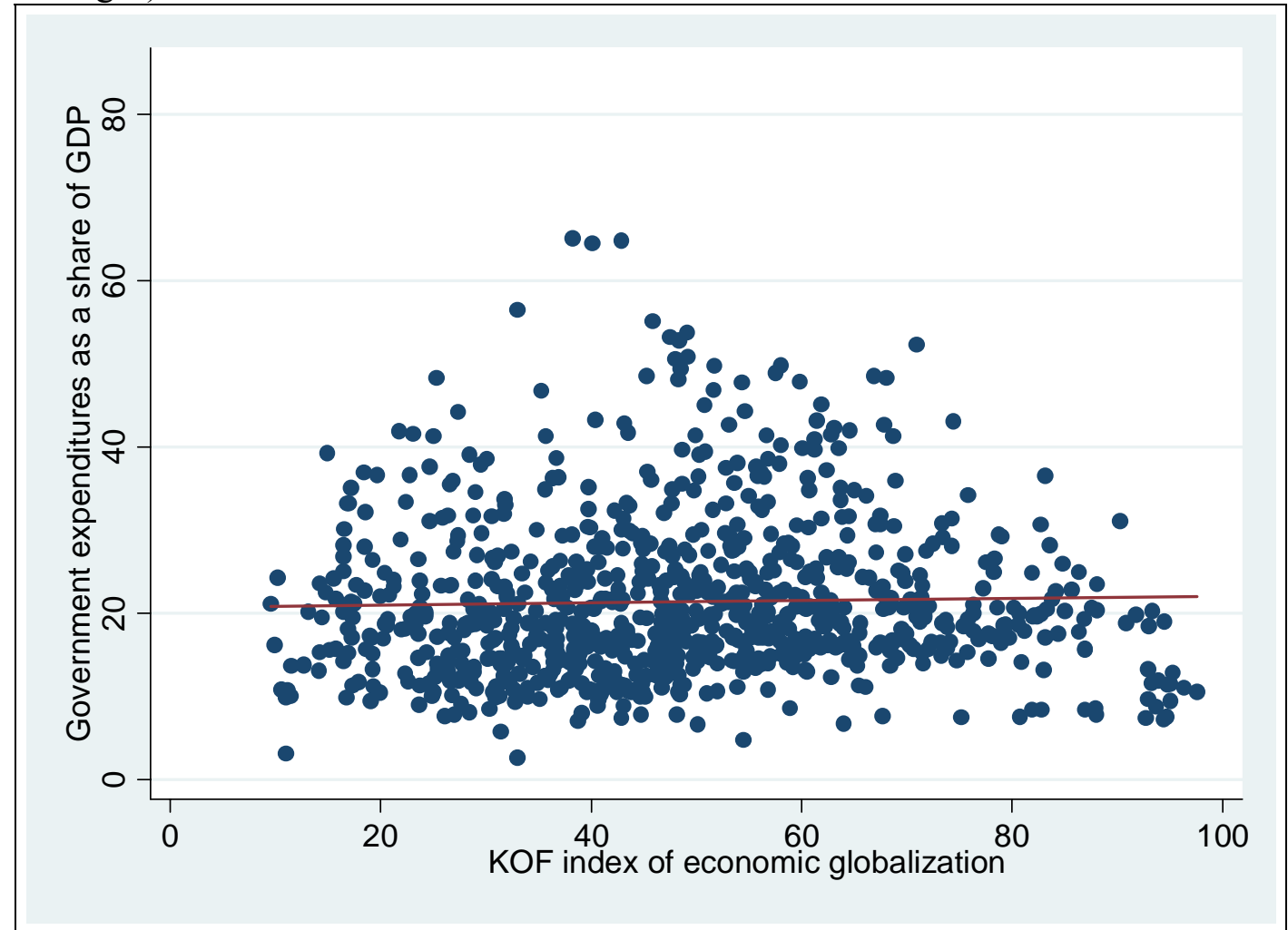

Correlation coefficient: 0.03. Source: Penn World Tables 6.2 and Dreher (2006) and Dreher et al. (2008a) 
Figure 5: Size of government and KOF index of social globalization 1970-2004 (five year averages).

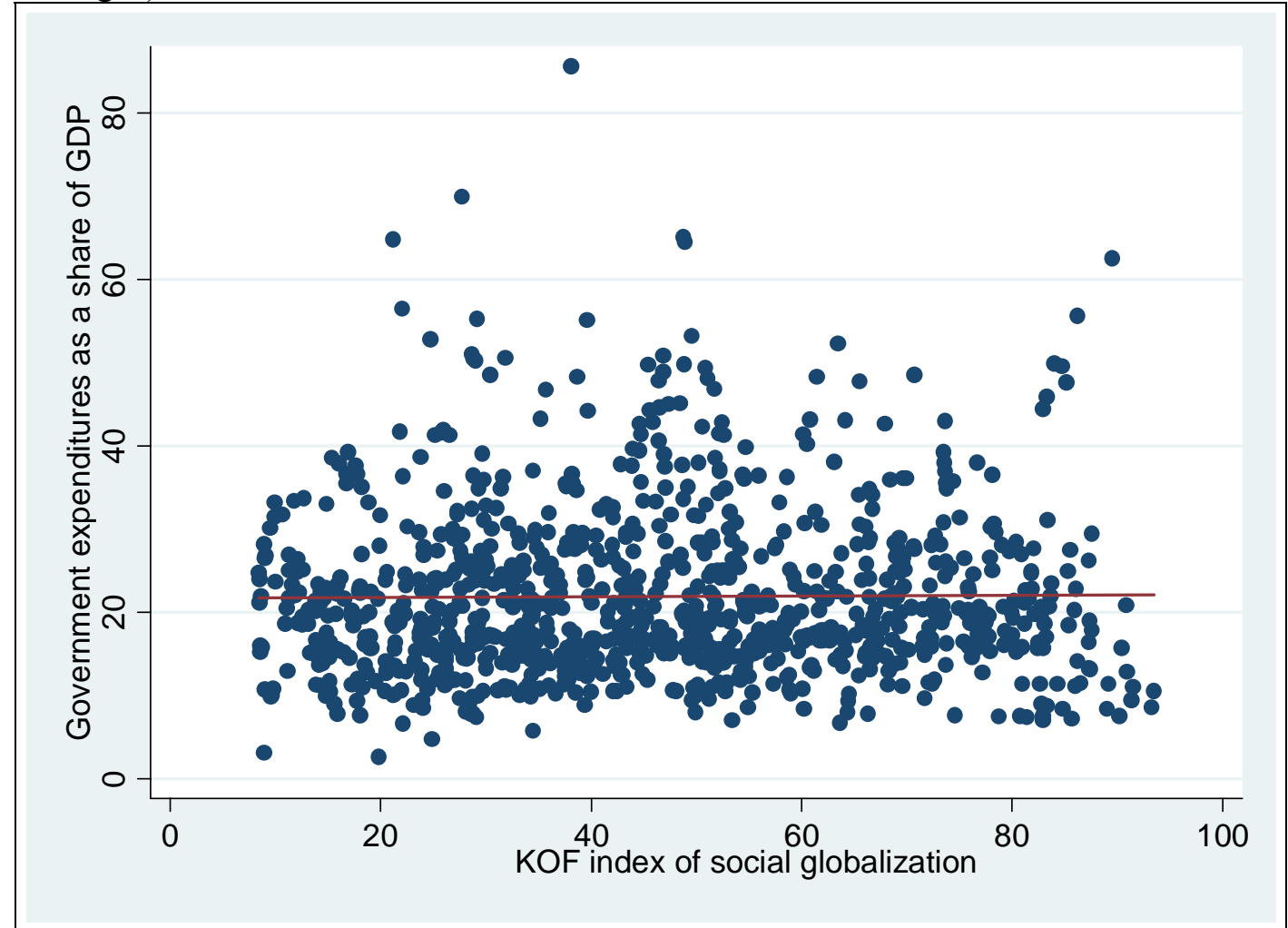

Correlation coefficient: 0.01. Source: Penn World Tables 6.2 and Dreher (2006) and Dreher et al. (2008a)

Figure 6: Size of government and KOF index of political globalization 1970-2004 (five year averages).

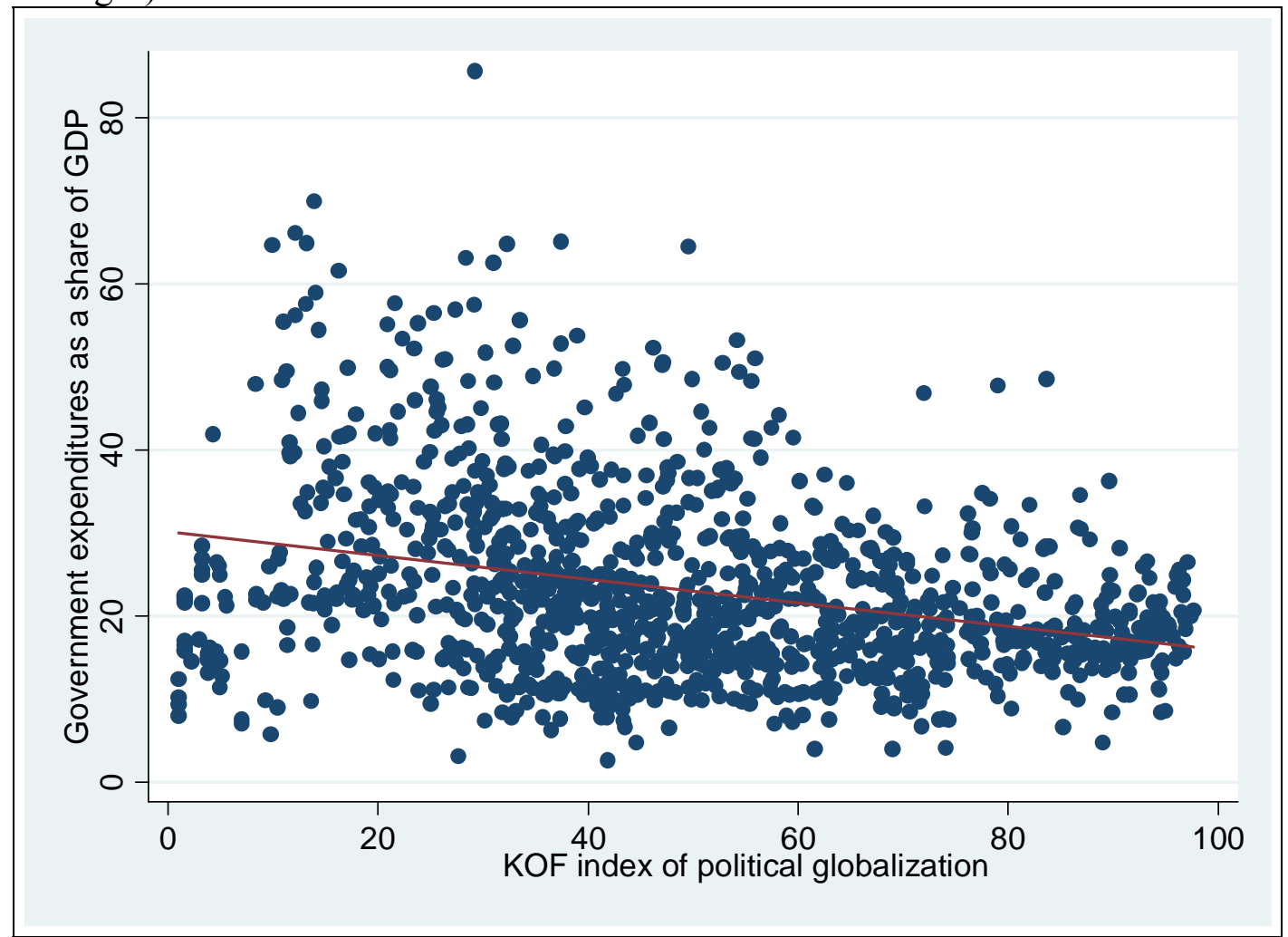

Correlation coefficient: -0.30. Source: Penn World Tables 6.2 and Dreher (2006) and Dreher et al. (2008a) 
Table 1: Regression Results.

Dependent variable: log Government expenditures as a share of GDP

FGLS with heteroskedastic and autocorrelation consistent (HAC) Newey-West type standard errors. 1970-2004 (five year averages)

\begin{tabular}{|c|c|c|c|c|c|}
\hline & (1) & (2) & (3) & (4) & $(5)$ \\
\hline log KOF index of globalization (overall) & $\begin{array}{c}0.2635^{* *} \\
{[2.01]}\end{array}$ & $\begin{array}{c}0.2921 * * \\
{[2.15]}\end{array}$ & & & \\
\hline $\log \mathrm{KOF}$ index of globalization (economic) & & & $\begin{array}{c}0.0453 \\
{[0.48]}\end{array}$ & & \\
\hline $\log$ KOF index of globalization (social) & & & & $\begin{array}{c}0.2782 * * * \\
{[3.06]}\end{array}$ & \\
\hline log KOF index of globalization (political) & & & & & $\begin{array}{c}0.1009 * \\
{[1.92]}\end{array}$ \\
\hline log real GDP per capita & & $\begin{array}{c}-0.0957 \\
{[1.55]}\end{array}$ & $\begin{array}{c}-0.1381 * * \\
{[2.03]}\end{array}$ & $\begin{array}{c}-0.1322 * * \\
{[2.14]}\end{array}$ & $\begin{array}{c}-0.0918 \\
{[1.60]}\end{array}$ \\
\hline log Dependency ratio & & $\begin{array}{c}0.286 \\
{[0.92]}\end{array}$ & $\begin{array}{c}0.4116 \\
{[1.23]}\end{array}$ & $\begin{array}{c}0.0023 \\
{[0.01]}\end{array}$ & $\begin{array}{c}0.3358 \\
{[1.05]}\end{array}$ \\
\hline log Population & & $\begin{array}{c}-0.0300 \\
{[0.36]}\end{array}$ & $\begin{array}{c}-0.1682 \\
{[1.62]}\end{array}$ & $\begin{array}{c}0.0159 \\
{[0.20]}\end{array}$ & $\begin{array}{c}-0.0475 \\
{[0.54]}\end{array}$ \\
\hline Fixed country effects & Yes & Yes & Yes & Yes & Yes \\
\hline Fixed period effects & Yes & Yes & Yes & Yes & Yes \\
\hline Observations & 980 & 966 & 876 & 981 & 1121 \\
\hline Number of countries & 155 & 153 & 139 & 156 & 179 \\
\hline R-squared (within) & 0.09 & 0.10 & 0.09 & 0.11 & 0.08 \\
\hline R-squared (between) & 0.00 & 0.06 & 0.08 & 0.10 & 0.07 \\
\hline
\end{tabular}

Notes: Absolute value of $t$ statistics in brackets; * significant at 10\%; ** significant at 5\%; $* *$ significant at $1 \%$ 
Table 2: Regression Results.

Dependent variable: $\log$ Government expenditures as a share of GDP

FGLS with heteroskedastic and autocorrelation consistent (HAC) Newey-West type standard errors. 1970-2004 (five year averages)

Cold War dummy variable included (1970-1989 period).

\begin{tabular}{|c|c|c|c|c|c|}
\hline & (1) & (2) & (3) & (4) & $(5)$ \\
\hline $\log \mathrm{KOF}$ index of globalization (overall) & $\begin{array}{c}0.0926^{*} \\
{[1.92]}\end{array}$ & $\begin{array}{c}0.1045^{* *} \\
{[2.07]}\end{array}$ & & & \\
\hline $\log \mathrm{KOF}$ index of globalization (economic) & & & $\begin{array}{c}-0.0012 \\
{[0.03]}\end{array}$ & & \\
\hline $\log \mathrm{KOF}$ index of globalization (social) & & & & $\begin{array}{c}0.1593 * * * \\
{[3.33]}\end{array}$ & \\
\hline log KOF index of globalization (political) & & & & & $\begin{array}{l}0.0668 \\
{[1.58]}\end{array}$ \\
\hline Cold War dummy variable & $\begin{array}{c}-0.0059 \\
{[0.16]}\end{array}$ & $\begin{array}{c}-0.1132 * * \\
{[2.37]}\end{array}$ & $\begin{array}{c}-0.2066^{* * *} \\
{[2.81]}\end{array}$ & $\begin{array}{c}-0.1448 * * * \\
{[3.07]}\end{array}$ & $\begin{array}{c}-0.1246^{* *} \\
{[2.52]}\end{array}$ \\
\hline $\log \mathrm{KOF}$ index of globalization (overall)* & & & & & \\
\hline Cold War dummy variable & $\begin{array}{l}0.0019 \\
{[0.16]}\end{array}$ & $\begin{array}{c}-0.0005 \\
{[0.04]}\end{array}$ & & & \\
\hline $\log \mathrm{KOF}$ index of globalization (economic)* & & & & & \\
\hline Cold War dummy variable & & & $\begin{array}{l}0.019 \\
{[1.35]}\end{array}$ & & \\
\hline $\log \mathrm{KOF}$ index of globalization (social)* & & & & & \\
\hline Cold War dummy variable & & & & $\begin{array}{c}-0.0127 \\
{[1.15]}\end{array}$ & \\
\hline $\log$ KOF index of globalization (political)* & & & & & \\
\hline Cold War dummy variable & & & & & $\begin{array}{l}0.0098 \\
{[0.76]}\end{array}$ \\
\hline log real GDP per capita & & $\begin{array}{c}-0.0959 \\
{[1.54]}\end{array}$ & $\begin{array}{c}-0.1293^{*} \\
{[1.88]}\end{array}$ & $\begin{array}{c}-0.1398 * * \\
{[2.30]}\end{array}$ & $\begin{array}{c}-0.0944 \\
{[1.64]}\end{array}$ \\
\hline $\log$ Dependency ratio & & $\begin{array}{l}0.2841 \\
{[0.96]}\end{array}$ & $\begin{array}{c}0.4693 \\
{[1.46]}\end{array}$ & $\begin{array}{c}-0.0689 \\
{[0.23]}\end{array}$ & $\begin{array}{c}0.3355 \\
{[1.05]}\end{array}$ \\
\hline log Population & & $\begin{array}{c}-0.0288 \\
{[0.32]}\end{array}$ & $\begin{array}{c}-0.2238 * * \\
{[1.99]}\end{array}$ & $\begin{array}{l}0.0433 \\
{[0.53]}\end{array}$ & $\begin{array}{c}-0.0566 \\
{[0.63]}\end{array}$ \\
\hline Fixed country effects & Yes & Yes & Yes & Yes & Yes \\
\hline Fixed period effects & Yes & Yes & Yes & Yes & Yes \\
\hline Observations & 980 & 966 & 876 & 981 & 1121 \\
\hline Number of countries & 155 & 153 & 139 & 156 & 179 \\
\hline R-squared (within) & 0.09 & 0.10 & 0.10 & 0.11 & 0.08 \\
\hline R-squared (between) & 0.00 & 0.06 & 0.07 & 0.05 & 0.10 \\
\hline
\end{tabular}

Notes: Absolute value of $\mathrm{t}$ statistics in brackets; * significant at 10\%; ** significant at 5\%; *** significant at $1 \%$

Table 3: Marginal effects (min and max). Cold War dummy variable included (1970-1989 period).

\begin{tabular}{l|ccccc}
\hline & $(1)$ & $(2)$ & $(3)$ & $(4)$ & $(5)$ \\
& $\begin{array}{c}\text { overall } \\
\text { globalization }\end{array}$ & $\begin{array}{c}\text { overall } \\
\text { globalization }\end{array}$ & $\begin{array}{c}\text { economic } \\
\text { globalization }\end{array}$ & $\begin{array}{c}\text { social } \\
\text { globalization }\end{array}$ & $\begin{array}{c}\text { political } \\
\text { globalization }\end{array}$ \\
\hline \multirow{2}{*}{$\mathbf{1 9 7 0 - 1 9 8 9}$ period } & $0.094^{* *}$ & $0.104 * *$ & 0.015 & $0.148^{* * *}$ & $0.075^{*}$ \\
& {$[2.02]$} & {$[2.15]$} & {$[0.37]$} & {$[3.16]$} & {$[1.86]$} \\
\hline \multirow{2}{*}{$\mathbf{1 9 9 0 - 2 0 0 4}$ period } & $0.090^{*}$ & $0.105^{*}$ & -0.023 & $0.174 * * *$ & 0.056 \\
& {$[1.70]$} & {$[1.87]$} & {$[0.45]$} & {$[3.34]$} & {$[1.14]$} \\
\hline
\end{tabular}

Notes: Absolute value of $t$ statistics in brackets; * significant at 10\%; ** significant at 5\%; *** significant at $1 \%$ 
Table 4: Regression Results.

Dependent variable: $\log$ Government expenditures as a share of GDP

FGLS with heteroskedastic and autocorrelation consistent (HAC) Newey-West type standard errors. 1970-2004 (five year averages)

Democracy-Dictatorship dummy variable included.

\begin{tabular}{|c|c|c|c|c|c|}
\hline & (1) & (2) & (3) & (4) & $(5)$ \\
\hline $\log \mathrm{KOF}$ index of globalization (overall) & $\begin{array}{c}0.1053 * * \\
{[2.20]}\end{array}$ & $\begin{array}{c}0.1202 * * \\
{[2.44]}\end{array}$ & & & \\
\hline $\log \mathrm{KOF}$ index of globalization (economic) & & & $\begin{array}{c}0.0136 \\
{[0.32]}\end{array}$ & & \\
\hline $\log \mathrm{KOF}$ index of globalization (social) & & & & $\begin{array}{c}0.1590 * * * \\
{[3.27]}\end{array}$ & \\
\hline log KOF index of globalization (political) & & & & & $\begin{array}{c}0.0785^{*} \\
{[1.68]}\end{array}$ \\
\hline Democracy & $\begin{array}{c}-0.0006 \\
{[0.03]}\end{array}$ & $\begin{array}{c}-0.0002 \\
{[0.01]}\end{array}$ & $\begin{array}{l}0.0055 \\
{[0.27]}\end{array}$ & $\begin{array}{c}-0.0029 \\
{[0.15]}\end{array}$ & $\begin{array}{l}0.0277 \\
{[0.99]}\end{array}$ \\
\hline $\log \mathrm{KOF}$ index of globalization (overall)* & & & & & \\
\hline Democracy & $\begin{array}{c}-0.0055 \\
{[0.31]}\end{array}$ & $\begin{array}{c}-0.0026 \\
{[0.13]}\end{array}$ & & & \\
\hline $\log \mathrm{KOF}$ index of globalization (economic)* & & & & & \\
\hline Democracy & & & $\begin{array}{c}-0.0175 \\
{[0.85]}\end{array}$ & & \\
\hline $\log \mathrm{KOF}$ index of globalization (social)* & & & & & \\
\hline Democracy & & & & $\begin{array}{c}-0.0053 \\
{[0.27]}\end{array}$ & \\
\hline $\log$ KOF index of globalization (political)* & & & & & \\
\hline Democracy & & & & & $\begin{array}{c}-0.0096 \\
{[0.28]}\end{array}$ \\
\hline log real GDP per capita & & $\begin{array}{c}-0.1143^{*} \\
{[1.89]}\end{array}$ & $\begin{array}{c}-0.1299 * \\
{[1.91]}\end{array}$ & $\begin{array}{c}-0.1531 * * \\
{[2.52]}\end{array}$ & $\begin{array}{c}-0.1009 * \\
{[1.71]}\end{array}$ \\
\hline log Dependency ratio & & $\begin{array}{c}0.2862 \\
{[0.88]}\end{array}$ & $\begin{array}{c}0.4156 \\
{[1.22]}\end{array}$ & $\begin{array}{c}0.018 \\
{[0.06]}\end{array}$ & $\begin{array}{c}0.4462 \\
{[1.28]}\end{array}$ \\
\hline log Population & & $\begin{array}{c}-0.0402 \\
{[0.42]}\end{array}$ & $\begin{array}{c}-0.2056^{*} \\
{[1.78]}\end{array}$ & $\begin{array}{c}0.0102 \\
{[0.11]}\end{array}$ & $\begin{array}{c}-0.0634 \\
{[0.65]}\end{array}$ \\
\hline Fixed country effects & Yes & Yes & Yes & Yes & Yes \\
\hline Fixed period effects & Yes & Yes & Yes & Yes & Yes \\
\hline Observations & 952 & 941 & 864 & 949 & 1071 \\
\hline Number of countries & 154 & 152 & 139 & 154 & 176 \\
\hline R-squared (within) & 0.10 & 0.11 & 0.10 & 0.12 & 0.08 \\
\hline R-squared (between) & 0.00 & 0.08 & 0.08 & 0.11 & 0.07 \\
\hline
\end{tabular}

Notes: Absolute value of $t$ statistics in brackets; * significant at $10 \% ; * *$ significant at $5 \%$; $* * *$ significant at $1 \%$

Table 5: Marginal effects (min and max). Democracy-Dictatorship dummy variable included.

\begin{tabular}{l|ccccc}
\hline & $(1)$ & $(2)$ & $(3)$ & $(4)$ & $(5)$ \\
& $\begin{array}{c}\text { overall } \\
\text { globalization }\end{array}$ & $\begin{array}{c}\text { overall } \\
\text { globalization }\end{array}$ & $\begin{array}{c}\text { economic } \\
\text { globalization }\end{array}$ & $\begin{array}{c}\text { social } \\
\text { globalization }\end{array}$ & $\begin{array}{c}\text { political } \\
\text { globalization }\end{array}$ \\
\hline \multirow{2}{*}{ Democracy } & $0.099 *$ & $0.117 * *$ & -0.007 & $0.153 * * *$ & 0.067 \\
& {$[1.83]$} & {$[2.07]$} & {$[0.13]$} & {$[2.91]$} & {$[1.07]$} \\
\hline \multirow{2}{*}{ Dictatorship } & $0.110 * *$ & $0.123 * *$ & 0.029 & $0.164 * * *$ & 0.087 \\
& {$[2.26]$} & {$[2.43]$} & {$[0.28]$} & {$[3.11]$} & {$[1.60]$} \\
\hline
\end{tabular}

Notes: Absolute value of $t$ statistics in brackets; * significant at 10\%; ** significant at 5\%; *** significant at $1 \%$ 
Table 6: Regression Results.

Dependent variable: $\log$ Government expenditures as a share of GDP

FGLS with heteroskedastic and autocorrelation consistent (HAC) Newey-West type standard errors. 1970-2004 (five year averages)

OECD country dummy variable included.

(1)

$\begin{array}{cc}0.1017^{* *} & 0.1156^{* *} \\ {[2.22]} & {[2.39]}\end{array}$

$\log$ KOF index of globalization (economic)

$\log \mathrm{KOF}$ index of globalization (social)

$\log$ KOF index of globalization (political)

OECD country

$\log$ KOF index of globalization (overall)*

OECD country

$\log$ KOF index of globalization (economic)*

OECD country

$\log$ KOF index of globalization (social)*

OECD country

$\log \mathrm{KOF}$ index of globalization (political)*

OECD country

$\begin{array}{cc}-0.0376 & -0.0475^{* *} \\ {[1.55]} & {[2.18]} \\ 0.0194 & 0.0312^{*} \\ {[1.27]} & {[1.94]}\end{array}$

0.0176

[1.07]

0.0254
$[0.63]$

(3) (4)

(4) (5)

$0.1498 * * *$

[3.12]

$0.1057^{* *}$

[2.42]

$-0.0753^{*}$

[1.76] $\log$ real GDP per capita

$\log$ Dependency ratio

$\log$ Population

Fixed country effects

Fixed period effects

Observations

Number of countries

R-squared (within)

R-squared (between)

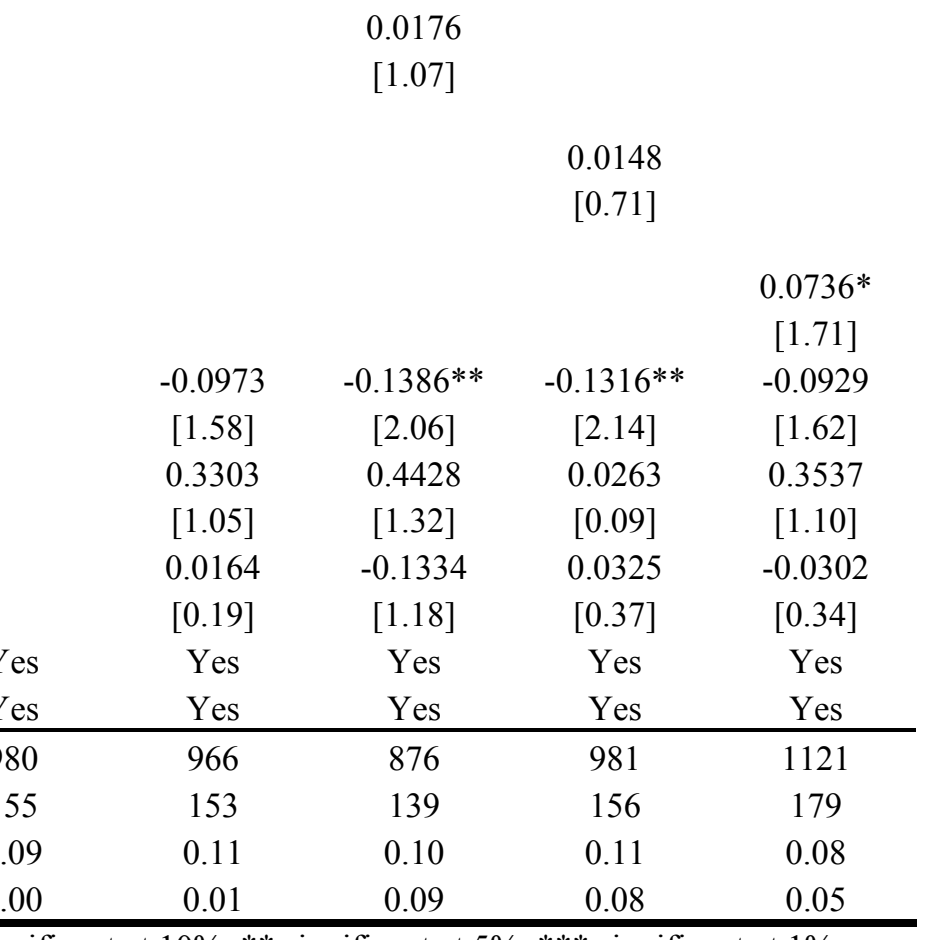

Notes: Absolute value of $t$ statistics in brackets; * significant at $10 \% ; * *$ significant at $5 \%$; *** significant at $1 \%$

Table 7: Marginal effects ( $\min$ and $\max$ ). OECD country dummy variable included.

\begin{tabular}{l|ccccc}
\hline & $(1)$ & $(2)$ & $(3)$ & $(4)$ & $(5)$ \\
& $\begin{array}{c}\text { overall } \\
\text { globalization }\end{array}$ & $\begin{array}{c}\text { overall } \\
\text { globalization }\end{array}$ & $\begin{array}{c}\text { economic } \\
\text { globalization }\end{array}$ & $\begin{array}{c}\text { social } \\
\text { globalization }\end{array}$ & $\begin{array}{c}\text { political } \\
\text { globalization }\end{array}$ \\
\hline \multirow{2}{*}{ OECD } & $0.150^{* *}$ & $0.194^{* * *}$ & 0.070 & $0.187^{* * *}$ & $0.290^{* *}$ \\
& {$[2.50]$} & {$[2.96]$} & {$[1.29]$} & {$[2.73]$} & {$[2.22]$} \\
\hline \multirow{2}{*}{ Non-OECD } & $0.094^{* *}$ & $0.103 * *$ & 0.018 & $0.144^{* * *}$ & $0.076^{*}$ \\
& {$[2.03]$} & {$[2.13]$} & {$[0.44]$} & {$[2.93]$} & {$[1.88]$} \\
\hline
\end{tabular}

Notes: Absolute value of $t$ statistics in brackets; $*$ significant at 10\%; ** significant at 5\%; $* * *$ significant at $1 \%$ 
Table 8: Regression Results.

Dependent variable: $\log$ Government expenditures as a share of GDP

FGLS with heteroskedastic and autocorrelation consistent (HAC) Newey-West type standard errors. 1970-2004 (five year averages)

Globalization and real GDP per capita interacted.

\begin{tabular}{|c|c|c|c|c|c|}
\hline & (1) & (2) & (3) & (4) & $(5)$ \\
\hline $\log$ KOF index of globalization (overall) & $\begin{array}{c}0.1042 * \\
{[1.95]}\end{array}$ & $\begin{array}{c}0.0985^{*} \\
{[1.84]}\end{array}$ & & & \\
\hline $\log \mathrm{KOF}$ index of globalization (economic) & & & $\begin{array}{c}-0.0129 \\
{[0.27]}\end{array}$ & & \\
\hline $\log \mathrm{KOF}$ index of globalization (social) & & & & $\begin{array}{c}0.1391 * * * \\
{[2.69]}\end{array}$ & \\
\hline log KOF index of globalization (political) & & & & & $\begin{array}{c}0.0698 * \\
{[1.85]}\end{array}$ \\
\hline log real GDP per capita & $\begin{array}{c}-0.0950 \\
{[1.35]}\end{array}$ & $\begin{array}{c}-0.1169 \\
{[1.53]}\end{array}$ & $\begin{array}{c}-0.1634^{*} \\
{[1.92]}\end{array}$ & $\begin{array}{c}-0.1613 * * \\
{[2.12]}\end{array}$ & $\begin{array}{c}-0.1162 \\
{[1.63]}\end{array}$ \\
\hline \multicolumn{6}{|l|}{$\log$ KOF index of globalization (overall)* } \\
\hline log real GDP per capita & $\begin{array}{c}0.0013 \\
{[0.08]}\end{array}$ & $\begin{array}{c}-0.0045 \\
{[0.25]}\end{array}$ & & & \\
\hline \multicolumn{6}{|l|}{$\log \mathrm{KOF}$ index of globalization (economic)* } \\
\hline log real GDP per capita & & & $\begin{array}{c}-0.0271 \\
{[1.25]}\end{array}$ & & \\
\hline \multicolumn{6}{|l|}{$\log \mathrm{KOF}$ index of globalization (social)* } \\
\hline log real GDP per capita & & & & $\begin{array}{c}-0.0075 \\
{[0.40]}\end{array}$ & \\
\hline \multicolumn{6}{|l|}{$\log$ KOF index of globalization (political)* } \\
\hline log real GDP per capita & & & & & $\begin{array}{c}-0.0102 \\
{[0.52]}\end{array}$ \\
\hline log Dependency ratio & & 0.3069 & $0.5214^{*}$ & 0.0268 & 0.359 \\
\hline & & {$[1.06]$} & {$[1.67]$} & {$[0.09]$} & [1.13] \\
\hline log Population & & $\begin{array}{c}-0.0403 \\
{[0.42]}\end{array}$ & $\begin{array}{c}-0.2612 * * \\
{[2.05]}\end{array}$ & $\begin{array}{c}0.001 \\
{[0.01]}\end{array}$ & $\begin{array}{c}-0.0547 \\
{[0.60]}\end{array}$ \\
\hline Fixed country effects & Yes & Yes & Yes & Yes & Yes \\
\hline Fixed period effects & Yes & Yes & Yes & Yes & Yes \\
\hline Observations & 980 & 966 & 876 & 981 & 1121 \\
\hline Number of countries & 155 & 153 & 139 & 156 & 179 \\
\hline R-squared (within) & 0.10 & 0.10 & 0.10 & 0.11 & 0.08 \\
\hline R-squared (between) & 0.04 & 0.07 & 0.07 & 0.09 & 0.09 \\
\hline
\end{tabular}

Notes: Absolute value of t statistics in brackets; * significant at 10\%; ** significant at 5\%; *** significant at $1 \%$

Table 9: Marginal effects ( $\min$ and max). Globalization and real GDP per capita interacted.

\begin{tabular}{l|ccccc}
\hline & $(1)$ & $(2)$ & $(3)$ & $(4)$ & $(5)$ \\
& $\begin{array}{c}\text { overall } \\
\text { globalization }\end{array}$ & $\begin{array}{c}\text { overall } \\
\text { globalization }\end{array}$ & $\begin{array}{c}\text { economic } \\
\text { globalization }\end{array}$ & $\begin{array}{c}\text { social } \\
\text { globalization }\end{array}$ & $\begin{array}{c}\text { political } \\
\text { globalization }\end{array}$ \\
\hline Low income (min) & $0.100^{*}$ & $0.112^{*}$ & 0.068 & $0.162^{* * *}$ & 0.100 \\
& {$[1.83]$} & {$[1.95]$} & {$[1.16]$} & {$[2.60]$} & {$[1.40]$} \\
\hline High income (max) & 0.107 & 0.088 & -0.076 & 0.121 & 0.046 \\
& {$[1.37]$} & {$[1.10]$} & {$[0.90]$} & {$[1.55]$} & {$[0.80]$} \\
\hline
\end{tabular}

Notes: Absolute value of $t$ statistics in brackets; $*$ significant at $10 \% ; * *$ significant at $5 \%$; ** significant at $1 \%$ 
Table 10: Regression Results.

Dependent variable: log Price level of Government divided by price level of GDP

FGLS with heteroskedastic and autocorrelation consistent (HAC) Newey-West type standard errors. 1970-2004 (five year averages)

\begin{tabular}{|c|c|c|c|c|c|}
\hline & (1) & (2) & (3) & (4) & $(5)$ \\
\hline $\log \mathrm{KOF}$ index of globalization (overall) & $\begin{array}{c}-0.1614 \\
{[1.48]}\end{array}$ & $\begin{array}{c}-0.2344 * * \\
{[2.37]}\end{array}$ & & & \\
\hline $\log \mathrm{KOF}$ index of globalization (economic) & & & $\begin{array}{c}-0.1247 * * \\
{[2.02]}\end{array}$ & & \\
\hline $\log \mathrm{KOF}$ index of globalization (social) & & & & $\begin{array}{c}-0.0901 \\
{[1.36]}\end{array}$ & \\
\hline log KOF index of globalization (political) & & & & & $\begin{array}{c}-0.0571 \\
{[1.41]}\end{array}$ \\
\hline log real GDP per capita & & $\begin{array}{c}0.2139 * * * \\
{[3.46]}\end{array}$ & $\begin{array}{c}0.2277 * * * \\
{[3.15]}\end{array}$ & $\begin{array}{c}0.2032 * * * \\
{[3.41]}\end{array}$ & $\begin{array}{c}0.1213 * * \\
{[2.06]}\end{array}$ \\
\hline log Dependency ratio & & $\begin{array}{c}0.1994 \\
{[0.67]}\end{array}$ & $\begin{array}{c}0.0773 \\
{[0.24]}\end{array}$ & $\begin{array}{l}0.3151 \\
{[1.05]}\end{array}$ & $\begin{array}{c}0.3529 \\
{[1.17]}\end{array}$ \\
\hline log Population & & $\begin{array}{c}-0.0608 \\
{[0.76]}\end{array}$ & $\begin{array}{c}-0.1215 \\
{[1.08]}\end{array}$ & $\begin{array}{c}-0.0868 \\
{[1.08]}\end{array}$ & $\begin{array}{c}-0.1085 \\
{[1.35]}\end{array}$ \\
\hline Fixed country effects & Yes & Yes & Yes & Yes & Yes \\
\hline Fixed period effects & Yes & Yes & Yes & Yes & Yes \\
\hline Observations & 980 & 966 & 876 & 981 & 1121 \\
\hline Number of countries & 155 & 153 & 139 & 156 & 179 \\
\hline R-squared (within) & 0.03 & 0.1 & 0.12 & 0.09 & 0.08 \\
\hline R-squared (between) & 0.17 & 0.16 & 0.18 & 0.10 & 0.12 \\
\hline
\end{tabular}

Notes: Absolute value of $t$ statistics in brackets; * significant at 10\%; ** significant at 5\%; *** significant at $1 \%$ 
Table A1. List of countries included.

\begin{tabular}{|c|c|}
\hline Afghanistan & Denmark \\
\hline Albania & Djibouti \\
\hline Algeria & Dominica \\
\hline Angola & Dominican Republic \\
\hline Antigua and Barbuda & Ecuador \\
\hline Argentina & Egypt, Arab Rep. \\
\hline Armenia & El Salvador \\
\hline Australia & Equatorial Guinea \\
\hline Austria & Eritrea \\
\hline Azerbaijan & Estonia \\
\hline Bahamas, The & Ethiopia \\
\hline Bahrain & Fiji \\
\hline Bangladesh & Finland \\
\hline Barbados & France \\
\hline Belarus & Gabon \\
\hline Belgium & Gambia, The \\
\hline Belize & Georgia \\
\hline Benin & Germany \\
\hline Bermuda & Ghana \\
\hline Bhutan & Greece \\
\hline Bolivia & Grenada \\
\hline Bosnia and Herzegovina & Guatemala \\
\hline Botswana & Guinea \\
\hline Brazil & Guinea-Bissau \\
\hline Brunei Darussalam & Guyana \\
\hline Bulgaria & Haiti \\
\hline Burkina Faso & Honduras \\
\hline Burundi & Hungary \\
\hline Cambodia & Iceland \\
\hline Cameroon & India \\
\hline Canada & Indonesia \\
\hline Cape Verde & Iran, Islamic Rep. \\
\hline Central African Republic & Iraq \\
\hline Chad & Ireland \\
\hline Chile & Israel \\
\hline China & Italy \\
\hline Colombia & Jamaica \\
\hline Comoros & Japan \\
\hline Congo, Dem. Rep. & Jordan \\
\hline Congo, Rep. & Kazakhstan \\
\hline Costa Rica & Kenya \\
\hline Cote d'Ivoire & Kiribati \\
\hline Croatia & Korea, Dem. Rep. \\
\hline Cuba & Korea, Rep. \\
\hline Cyprus & Kuwait \\
\hline Czech Republic & Kyrgyz Republic \\
\hline Lao PDR & Rwanda \\
\hline Latvia & Samoa \\
\hline Lebanon & Sao Tome and Principe \\
\hline
\end{tabular}


Lesotho

Liberia

Libya

Lithuania

Luxembourg

Macao, China

Macedonia, FYR

Madagascar

Malawi

Malaysia

Maldives

Mali

Malta

Mauritania

Mauritius

Mexico

Micronesia, Fed. Sts.

Moldova

Mongolia

Morocco

Mozambique

Namibia

Nepal

Netherlands

Netherlands Antilles

New Zealand

Nicaragua

Niger

Nigeria

Norway

Oman

Pakistan

Palau

Panama

Papua New Guinea

Paraguay

Peru

Philippines

Poland

Portugal

Puerto Rico

Qatar

Romania

Russian Federation
Saudi Arabia

Senegal

Serbia

Seychelles

Sierra Leone

Singapore

Slovak Republic

Slovenia

Solomon Islands

Somalia

South Africa

Spain

Sri Lanka

St. Kitts and Nevis

St. Lucia

St. Vincent and the Grenadines

Sudan

Suriname

Swaziland

Sweden

Switzerland

Syrian Arab Republic

Tajikistan

Tanzania

Thailand

Togo

Tonga

Trinidad and Tobago

Tunisia

Turkey

Turkmenistan

Uganda

Ukraine

United Arab Emirates

United Kingdom

United States

Uruguay

Uzbekistan

Vanuatu

Venezuela, RB

Vietnam

Yemen, Rep.

Zambia

Zimbabwe 
Table A2. Data description and sources

\begin{tabular}{|c|c|c|c|c|c|c|}
\hline Variable & Observations & Mean & Std. Dev. & Min & Max & Source \\
\hline & & & & & & Penn World Tables 6.2 \\
\hline Government sector size & 5710 & 22.94 & 11.22 & 2.12 & 106.60 & Summers and Heston (1991) \\
\hline KOF index of globalization & & & & & & Dreher (2006) and Dreher et \\
\hline (overall) & 5210 & 47.91 & 16.51 & 13.22 & 93.46 & al. (2008) \\
\hline $\begin{array}{l}\text { KOF index of globalization } \\
\text { (economic) }\end{array}$ & 4650 & 48.19 & 18.57 & 8.68 & 98.72 & $\begin{array}{l}\text { Dreher (2006) and Dreher et } \\
\text { al. (2008) }\end{array}$ \\
\hline $\begin{array}{l}\text { KOF index of globalization } \\
\text { (social) }\end{array}$ & 5315 & 45.50 & 20.72 & 7.23 & 94.44 & $\begin{array}{l}\text { Dreher (2006) and Dreher et } \\
\text { al. (2008) }\end{array}$ \\
\hline $\begin{array}{l}\text { KOF index of globalization } \\
\text { (political) }\end{array}$ & 6295 & 47.40 & 24.93 & 1 & 98.78 & $\begin{array}{l}\text { Dreher (2006) and Dreher et } \\
\text { al. (2008) } \\
\text { Penn World Tables } 62\end{array}$ \\
\hline GDP per capita (real) & 5710 & 5742.86 & 7002.58 & 61.06 & 54285.46 & Summers and Heston (1991) \\
\hline Dependency ratio & 6225 & 58.17 & 6.69 & 45.22 & 78.56 & Worldbank (2009) \\
\hline $\begin{array}{l}\text { Population (total) in } \\
\text { thousands }\end{array}$ & 6509 & 26823.59 & 103104.90 & 12.01 & 1294846 & $\begin{array}{l}\text { Penn World Tables } 6.2 \\
\text { Summers and Heston (1991) }\end{array}$ \\
\hline Cold War dummy variable & 6510 & 0.57 & 0.50 & 0 & 1 & Own calculation \\
\hline Democracy & 5605 & 0.43 & 0.50 & 0 & 1 & Cheibub et al. (2010) \\
\hline OECD dummy variable & 6510 & 0.14 & 0.34 & 0 & 1 & $\begin{array}{l}\text { Own calculation } \\
\text { Penn World Tables } 6.2\end{array}$ \\
\hline Relative price of Government & 5710 & 0.83 & 0.43 & 0.15 & 5.77 & Summers and Heston (1991) \\
\hline
\end{tabular}


Table A3. Construction of the KOF index of globalization

Indices and Variables

Weights

\begin{tabular}{llc}
\hline I) & Economic Globalization & $\mathbf{3 8} \mathbf{\%}$ \\
i) & \\
& Actual Flows & $\mathbf{5 0} \%$ \\
& $19 \%$ \\
& Frade (percent of GDP) & $20 \%$ \\
& Foreign Direct Investment, flows (percent of GDP) & $23 \%$ \\
& Portfolio Investment (percent of GDP) & $17 \%$ \\
& Income Payments to Foreign Nationals (percent of GDP) & $21 \%$ \\
ii) & $50 \%$ \\
& Restrictions & $21 \%$ \\
& $29 \%$ \\
& Mean Tariff Rate & $25 \%$ \\
& Caxes on International Trade (percent of current revenue) \\
& $25 \%$ \\
\hline
\end{tabular}

\begin{tabular}{ll}
\hline II) Social Globalization & $39 \%$
\end{tabular}

i) Data on Personal Contact $34 \%$

Telephone Traffic $\quad 26 \%$

Transfers (percent of GDP) $\quad 3 \%$

International Tourism $\quad 26 \%$

Foreign Population (percent of total population) $\quad 20 \%$

International letters (per capita) $\quad 26 \%$

ii) Data on Information Flows $\quad 34 \%$

Internet Users (per 1000 people) $\quad 36 \%$

Television (per 1000 people) $\quad 36 \%$

Trade in Newspapers (percent of GDP) $28 \%$

iii) Data on Cultural Proximity $32 \%$

Number of McDonald's Restaurants (per capita) $\quad 37 \%$

Number of Ikea (per capita) $\quad 39 \%$

Trade in books (percent of GDP) $\quad 24 \%$

\begin{tabular}{ll}
\hline III) Political Globalization & $\mathbf{2 3} \mathbf{\%}$ \\
& \\
Embassies in Country & $25 \%$ \\
Membership in International Organizations & $28 \%$ \\
Participation in U.N. Security Council Missions & $22 \%$ \\
International Treaties & $25 \%$ \\
\hline
\end{tabular}


Additional Tables and Figures 
Table B1: Regression Results.

Dependent variable: Government expenditures as a share of GDP

FGLS with heteroskedastic and autocorrelation consistent (HAC) Newey-West type standard errors. 1970-2004 (five year averages)

\begin{tabular}{lccccc}
\hline & $(1)$ & $(2)$ & $(3)$ & $(4)$ & $(5)$ \\
\hline KOF index of globalization (overall) & 0.0259 & 0.0374 & & & \\
KOF index of globalization (economic) & {$[0.41]$} & {$[0.61]$} & & & \\
& & & -0.0058 & & \\
KOF index of globalization (social) & & & {$[0.12]$} & & \\
& & & & $0.0829^{*}$ & \\
KOF index of globalization (political) & & & & {$[1.86]$} & \\
& & & & -0.0009 \\
real GDP per capita & & -0.0001 & -0.0001 & $-0.0001^{* *}$ & -0.0001 \\
& & {$[1.19]$} & {$[1.49]$} & {$[2.35]$} & {$[1.45]$} \\
Dependency ratio & -0.0025 & -0.0115 & -0.1179 & -0.002 \\
& & {$[0.02]$} & {$[0.10]$} & {$[0.93]$} & {$[0.02]$} \\
Population & & $1 \times 10^{-7}$ & $1 \times 10^{-5 * *}$ & $8 \times 10^{-6}$ & $1 \times 10^{-5}$ \\
& {$[1.58]$} & {$[2.21]$} & {$[1.37]$} & {$[1.62]$} \\
Fixed country effects & & Yes & Yes & Yes & Yes \\
Fixed period effects & Yes & Yes & Yes & Yes & Yes \\
\hline Observations & Yes & 966 & 876 & 981 & 1121 \\
Number of countries & 980 & 153 & 139 & 156 & 179 \\
R-squared (within) & 155 & 0.06 & 0.05 & 0.05 & 0.04 \\
R-squared (between) & 0.05 & 0.00 & 0.02 & 0.06 & 0.03 \\
\hline Nit Absol
\end{tabular}

Notes: Absolute value of $\mathrm{t}$ statistics in brackets; * significant at $10 \% ; * *$ significant at $5 \% ; * * *$ significant at $1 \%$ 
Table B2: Regression Results.

Dependent variable: Government expenditures as a share of GDP

FGLS with heteroskedastic and autocorrelation consistent (HAC) Newey-West type standard errors.

1970-2004 (five year averages)

Cold War dummy variable included (1970-1989 period).

\begin{tabular}{|c|c|c|c|c|c|}
\hline & (1) & (2) & (3) & (4) & (5) \\
\hline KOF index of globalization (overall) & $\begin{array}{l}0.6437 \\
{[0.62]}\end{array}$ & $\begin{array}{l}0.6359 \\
{[0.61]}\end{array}$ & & & \\
\hline KOF index of globalization (economic) & & & $\begin{array}{c}-0.0926 \\
{[0.10]}\end{array}$ & & \\
\hline KOF index of globalization (social) & & & & $\begin{array}{c}1.6066^{*} \\
{[1.80]}\end{array}$ & \\
\hline KOF index of globalization (political) & & & & & $\begin{array}{l}0.0802 \\
{[0.10]}\end{array}$ \\
\hline Cold War dummy variable & $\begin{array}{c}-0.7082 \\
{[0.94]}\end{array}$ & $\begin{array}{c}-1.3919 * * * \\
{[2.74]}\end{array}$ & $\begin{array}{c}-1.2677 \\
{[1.53]}\end{array}$ & $\begin{array}{c}-1.8166^{* * *} \\
{[4.39]}\end{array}$ & $\begin{array}{c}-1.4158^{* * *} \\
{[3.07]}\end{array}$ \\
\hline KOF index of globalization (overall)* & & & & & \\
\hline Cold War dummy variable & $\begin{array}{l}0.1781 \\
{[0.90]}\end{array}$ & $\begin{array}{l}0.0276 \\
{[0.11]}\end{array}$ & & & \\
\hline KOF index of globalization (economic)* & & & & & \\
\hline Cold War dummy variable & & & $\begin{array}{l}0.1758 \\
{[0.62]}\end{array}$ & & \\
\hline KOF index of globalization (social)* & & & & & \\
\hline Cold War dummy variable & & & & $\begin{array}{c}-0.3883 \\
{[1.51]}\end{array}$ & \\
\hline KOF index of globalization (political)* & & & & & \\
\hline Cold War dummy variable & & & & & $\begin{array}{l}0.1858 \\
{[0.67]}\end{array}$ \\
\hline real GDP per capita & & $\begin{array}{c}-0.0001 \\
{[0.84]}\end{array}$ & $\begin{array}{c}-0.0001 \\
{[0.78]}\end{array}$ & $\begin{array}{c}-0.0002 * * * \\
{[2.80]}\end{array}$ & $\begin{array}{c}-0.0001 \\
{[1.09]}\end{array}$ \\
\hline Dependency ratio & & $\begin{array}{c}-0.0021 \\
{[0.02]}\end{array}$ & $\begin{array}{c}-0.0047 \\
{[0.04]}\end{array}$ & $\begin{array}{c}-0.1364 \\
{[1.10]}\end{array}$ & $\begin{array}{c}-0.0101 \\
{[0.08]}\end{array}$ \\
\hline Population & & $\begin{array}{l}9 \times 10^{-6} \\
{[1.56]}\end{array}$ & $\begin{array}{c}1 \times 10^{-5 * * *} \\
{[2.03]}\end{array}$ & $\begin{array}{c}1 \times 10^{-5 * *} \\
{[2.23]}\end{array}$ & $\begin{array}{c}1 \times 10^{-5 * *} \\
{[1.99]}\end{array}$ \\
\hline Fixed country effects & Yes & Yes & Yes & Yes & Yes \\
\hline Fixed period effects & Yes & Yes & Yes & Yes & Yes \\
\hline Observations & 980 & 966 & 876 & 981 & 1121 \\
\hline Number of countries & 155 & 153 & 139 & 156 & 179 \\
\hline R-squared (within) & 0.05 & 0.06 & 0.06 & 0.05 & 0.04 \\
\hline R-squared (between) & 0.00 & 0.00 & 0.01 & 0.07 & 0.01 \\
\hline
\end{tabular}

Notes: Absolute value of $\mathrm{t}$ statistics in brackets; * significant at $10 \% ; * *$ significant at $5 \% ; * * *$ significant at $1 \%$

Table B3: Marginal effects (min and max). Cold War dummy variable included (1970-1989 period).

\begin{tabular}{l|ccccc}
\hline & $(1)$ & $(2)$ & $(3)$ & $(4)$ & $(5)$ \\
& $\begin{array}{c}\text { overall } \\
\text { globalization }\end{array}$ & $\begin{array}{c}\text { overall } \\
\text { globalization }\end{array}$ & $\begin{array}{c}\text { economic } \\
\text { globalization }\end{array}$ & $\begin{array}{c}\text { social } \\
\text { globalization }\end{array}$ & $\begin{array}{c}\text { political } \\
\text { globalization }\end{array}$ \\
\hline \multirow{2}{*}{ 1970-1989 period } & 0.798 & 0.660 & 0.060 & 1.270 & -0.134 \\
& {$[0.75]$} & {$[0.59]$} & {$[0.06]$} & {$[1.40]$} & {$[0.17]$} \\
\hline \multirow{2}{*}{ 1990-2004 period } & 0.438 & 0.604 & -0.295 & $2.055^{* *}$ & 0.241 \\
& {$[0.42]$} & {$[0.60]$} & {$[0.32]$} & {$[2.14]$} & {$[0.29]$} \\
\hline
\end{tabular}

Notes: Absolute value of $t$ statistics in brackets; * significant at $10 \%$; ** significant at 5\%; *** significant at $1 \%$ 
Table B4: Regression Results.

Dependent variable: Government expenditures as a share of GDP

FGLS with heteroskedastic and autocorrelation consistent (HAC) Newey-West type standard errors.

1970-2004 (five year averages)

Democracy-Dictatorship dummy variable included.

\begin{tabular}{|c|c|c|c|c|c|}
\hline & (1) & (2) & (3) & (4) & (5) \\
\hline KOF index of globalization (overall) & $\begin{array}{l}0.8369 \\
{[0.73]}\end{array}$ & $\begin{array}{l}0.9449 \\
{[0.82]}\end{array}$ & & & \\
\hline KOF index of globalization (economic) & & & $\begin{array}{c}-0.0887 \\
{[0.09]}\end{array}$ & & \\
\hline KOF index of globalization (social) & & & & $\begin{array}{c}2.1960^{* *} \\
{[2.05]}\end{array}$ & \\
\hline KOF index of globalization (political) & & & & & $\begin{array}{c}-0.0874 \\
{[0.11]}\end{array}$ \\
\hline Democracy & $\begin{array}{l}0.0869 \\
{[0.19]}\end{array}$ & $\begin{array}{l}0.0728 \\
{[0.16]}\end{array}$ & $\begin{array}{l}0.2327 \\
{[0.44]}\end{array}$ & $\begin{array}{c}-0.1169 \\
{[0.24]}\end{array}$ & $\begin{array}{l}0.6265 \\
{[0.92]}\end{array}$ \\
\hline $\begin{array}{l}\text { KOF index of globalization (overall)* } \\
\text { Democracy }\end{array}$ & $\begin{array}{c}-0.1647 \\
{[0.40]}\end{array}$ & $\begin{array}{l}0.023 \\
{[0.05]}\end{array}$ & & & \\
\hline $\begin{array}{l}\log \text { KOF index of globalization (economic)* } \\
\text { Democracy }\end{array}$ & & & $\begin{array}{l}0.0577 \\
{[0.11]}\end{array}$ & & \\
\hline $\begin{array}{l}\text { KOF index of globalization (social)* } \\
\text { Democracy }\end{array}$ & & & & $\begin{array}{c}-0.2372 \\
{[0.53]}\end{array}$ & \\
\hline $\begin{array}{l}\text { KOF index of globalization (political)* } \\
\text { Democracy }\end{array}$ & & & & & $\begin{array}{c}-0.0957 \\
{[0.15]}\end{array}$ \\
\hline real GDP per capita & & $\begin{array}{c}-0.0001 \\
{[1.33]}\end{array}$ & $\begin{array}{c}-0.0001 \\
{[1.33]}\end{array}$ & $\begin{array}{c}-0.0001 * * \\
{[2.36]}\end{array}$ & $\begin{array}{c}-0.0001 \\
{[1.23]}\end{array}$ \\
\hline Dependency ratio & & $\begin{array}{c}-0.0138 \\
{[0.13]}\end{array}$ & $\begin{array}{c}-0.0238 \\
{[0.21]}\end{array}$ & $\begin{array}{c}-0.1365 \\
{[1.05]}\end{array}$ & $\begin{array}{l}0.0197 \\
{[0.14]}\end{array}$ \\
\hline Population & & $\begin{array}{l}9 \times 10^{-6} \\
{[1.48]}\end{array}$ & $\begin{array}{c}1 \times 10^{-5 *} \\
{[1.98]}\end{array}$ & $\begin{array}{l}8 \times 10^{-6} \\
{[1.24]}\end{array}$ & $\begin{array}{c}1 \times 10^{-5 *} \\
{[1.95]}\end{array}$ \\
\hline Fixed country effects & Yes & Yes & Yes & Yes & Yes \\
\hline Fixed period effects & Yes & Yes & Yes & Yes & Yes \\
\hline Observations & 952 & 941 & 864 & 949 & 1071 \\
\hline Number of countries & 154 & 152 & 139 & 154 & 176 \\
\hline R-squared (within) & 0.05 & 0.06 & 0.06 & 0.05 & 0.04 \\
\hline R-squared (between) & 0.00 & 0.00 & 0.01 & 0.05 & 0.00 \\
\hline
\end{tabular}

Notes: Absolute value of $t$ statistics in brackets; * significant at 10\%; ** significant at 5\%; $* *$ significant at $1 \%$

Table B5: Marginal effects (min and max). Democracy-Dictatorship dummy variable included.

\begin{tabular}{l|ccccc}
\hline \multirow{2}{*}{ Democracy } & $(1)$ & $(2)$ & $(3)$ & $(4)$ & $(5)$ \\
& $\begin{array}{c}\text { overall } \\
\text { globalization }\end{array}$ & $\begin{array}{c}\text { overall } \\
\text { globalization }\end{array}$ & $\begin{array}{c}\text { economic } \\
\text { globalization }\end{array}$ & $\begin{array}{c}\text { social } \\
\text { globalization }\end{array}$ & $\begin{array}{c}\text { political } \\
\text { globalization }\end{array}$ \\
\hline \multirow{2}{*}{ Dictatorship } & 0.644 & 0.972 & -0.021 & $1.918^{* *}$ & -0.199 \\
& {$[0.63]$} & {$[0.97]$} & {$[0.02]$} & {$[2.14]$} & {$[0.17]$} \\
\hline & 0.985 & $0.123^{* *}$ & -0.140 & $2.408^{*}$ & -0.001 \\
& {$[0.72]$} & {$[2.43]$} & {$[0.11]$} & {$[1.81]$} & {$[0.00]$} \\
\hline
\end{tabular}

Notes: Absolute value of $t$ statistics in brackets; * significant at $10 \%$; ** significant at $5 \%$; *** significant at $1 \%$ 
Table B6: Regression Results.

Dependent variable: Government expenditures as a share of GDP

FGLS with heteroskedastic and autocorrelation consistent (HAC) Newey-West type standard errors. 1970-2004 (five year averages)

OECD country dummy variable included.

$\begin{array}{llll}\text { (1) } & \text { (2) } & \text { (3) } & \text { (4) }\end{array}$

\begin{tabular}{lll}
\hline KOF index of globalization (overall) & 0.3547 & 0.3385 \\
& {$[0.32]$} & {$[0.31]$}
\end{tabular}

KOF index of globalization (economic)

-0.5597
$[0.56]$

KOF index of globalization (social)

KOF index of globalization (political)

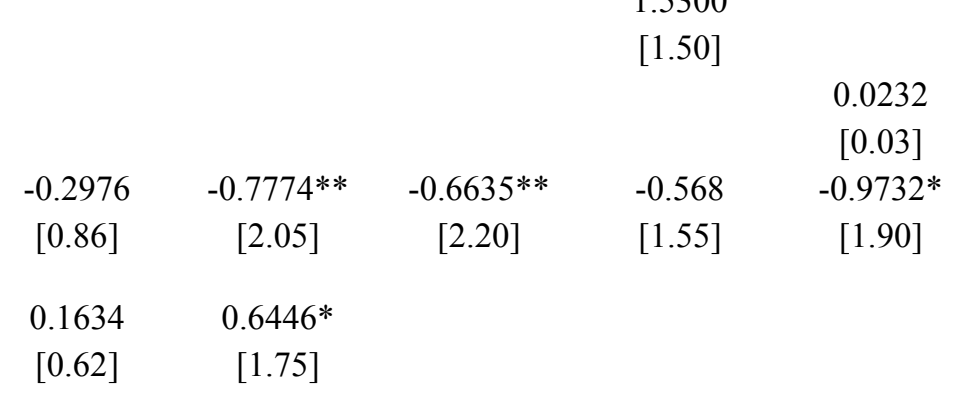

KOF index of globalization (economic)*

OECD country

KOF index of globalization (social)*

OECD country

KOF index of globalization (political)*

OECD country

real GDP per capita

$-0.0001^{*}$

$-0.0002 * *$

$-0.0002 * *$

$-0.0001^{*}$

Dependency ratio

[1.72]

[2.34]

[2.27]

[1.68]

0.0347

0.0377

$-0.0897$

0.0065

Population

[0.34]

$1 \times 10^{-5 *}$

[0.35]

[0.70]

[0.05]

Population

[1.74]

$1 \times 10^{-5 * *}$

$9 \times 10^{-6}$

$1 \times 10^{-5}$ *

Fixed country effects

Yes

[2.45]

[1.43]

[1.70]

Fixed period effects

Yes

Yes

Yes

Yes

Yes

Observations

980

Yes

Yes

Yes

Yes

Number of countries

R-squared (within)

155

966

876

981

1121

R-squared (between)

0.05

153

139

156

121

0.01

0.06

0.07

0.05

179

0.02

0.01

0.09

0.04

Notes: Absolute value of $t$ statistics in brackets; * significant at $10 \%$; ** significant at $5 \%$; *** significant at $1 \%$

Table B7: Marginal effects (min and max). OECD country dummy variable included.

\begin{tabular}{l|ccccc}
\hline \multirow{2}{*}{ OECD } & $(1)$ & $(2)$ & $(3)$ & $(4)$ & $(5)$ \\
& $\begin{array}{c}\text { overall } \\
\text { globalization }\end{array}$ & $\begin{array}{c}\text { overall } \\
\text { globalization }\end{array}$ & $\begin{array}{c}\text { economic } \\
\text { globalization }\end{array}$ & $\begin{array}{c}\text { social } \\
\text { globalization }\end{array}$ & $\begin{array}{c}\text { political } \\
\text { globalization }\end{array}$ \\
\hline \multirow{2}{*}{ Non-OECD } & 0.765 & $1.958^{*}$ & $1.821^{* *}$ & $2.684^{* *}$ & $1.877^{*}$ \\
& {$[0.76]$} & {$[1.89]$} & {$[2.17]$} & {$[2.46]$} & {$[1.84]$} \\
\hline & 0.290 & 0.082 & -0.937 & 1.347 & -0.270 \\
& {$[0.25]$} & {$[0.07]$} & {$[0.84]$} & {$[1.21]$} & {$[0.33]$} \\
\hline
\end{tabular}

Notes: Absolute value of $\mathrm{t}$ statistics in brackets; * significant at $10 \%$; ** significant at $5 \%$; *** significant at $1 \%$ 
Table B8: Regression Results.

Dependent variable: Government expenditures as a share of GDP

FGLS with heteroskedastic and autocorrelation consistent (HAC) Newey-West type standard errors. 1970-2004 (five year averages)

Globalization and real GDP per capita interacted.

\begin{tabular}{|c|c|c|c|c|c|}
\hline & (1) & (2) & (3) & (4) & $(5)$ \\
\hline $\log \mathrm{KOF}$ index of globalization (overall) & $\begin{array}{c}0.6186 \\
{[0.60]}\end{array}$ & $\begin{array}{l}0.6186 \\
{[0.61]}\end{array}$ & & & \\
\hline log KOF index of globalization (economic) & & & $\begin{array}{c}-0.0576 \\
{[0.06]}\end{array}$ & & \\
\hline $\log$ KOF index of globalization (social) & & & & $\begin{array}{c}1.9613 * * \\
{[2.02]}\end{array}$ & \\
\hline $\log$ KOF index of globalization (political) & & & & & $\begin{array}{l}0.0195 \\
{[0.03]}\end{array}$ \\
\hline log real GDP per capita & $\begin{array}{c}-0.7293 \\
{[0.73]}\end{array}$ & $\begin{array}{c}-0.9422 \\
{[0.82]}\end{array}$ & $\begin{array}{c}-1.2713 \\
{[1.25]}\end{array}$ & $\begin{array}{c}-2.3269^{*} \\
{[1.82]}\end{array}$ & $\begin{array}{c}-0.9879 \\
{[1.33]}\end{array}$ \\
\hline $\begin{array}{l}\text { log KOF index of globalization (overall)* } \\
\log \text { real GDP per capita }\end{array}$ & $\begin{array}{l}0.1293 \\
{[0.36]}\end{array}$ & $\begin{array}{l}0.2252 \\
{[0.52]}\end{array}$ & & & \\
\hline $\begin{array}{l}\text { log KOF index of globalization (economic)* } \\
\text { log real GDP per capita }\end{array}$ & & & $\begin{array}{l}0.3103 \\
{[0.75]}\end{array}$ & & \\
\hline $\begin{array}{l}\log \text { KOF index of globalization (social)* } \\
\text { log real GDP per capita }\end{array}$ & & & & $\begin{array}{l}0.6886 \\
{[1.24]}\end{array}$ & \\
\hline $\begin{array}{l}\text { log KOF index of globalization (political)* } \\
\text { log real GDP per capita }\end{array}$ & & & & & $\begin{array}{l}0.2597 \\
{[0.72]}\end{array}$ \\
\hline log Dependency ratio & & $\begin{array}{l}0.0149 \\
{[0.13]}\end{array}$ & $\begin{array}{l}0.0084 \\
{[0.07]}\end{array}$ & $\begin{array}{c}-0.0836 \\
{[0.64]}\end{array}$ & $\begin{array}{l}0.0138 \\
{[0.10]}\end{array}$ \\
\hline $\log$ Population & & $\begin{array}{c}1 \times 10^{-5 *} \\
{[1.73]}\end{array}$ & $\begin{array}{c}1 \times 10^{-5 * * *} \\
{[2.56]}\end{array}$ & $\begin{array}{l}1 \times 10^{-5 *} \\
{[1.84]}\end{array}$ & $\begin{array}{l}1 \times 10^{-7} \\
{[1.53]}\end{array}$ \\
\hline Fixed country effects & Yes & Yes & Yes & Yes & Yes \\
\hline Fixed period effects & Yes & Yes & Yes & Yes & Yes \\
\hline Observations & 980 & 966 & 876 & 981 & 1121 \\
\hline Number of countries & 155 & 153 & 139 & 156 & 179 \\
\hline R-squared (within) & 0.06 & 0.06 & 0.06 & 0.05 & 0.04 \\
\hline R-squared (between) & 0.07 & 0.01 & 0.02 & 0.06 & 0.03 \\
\hline
\end{tabular}

Notes: Absolute value of $\mathrm{t}$ statistics in brackets; $*$ significant at $10 \% ; * *$ significant at $5 \% ; * * *$ significant at $1 \%$

Table B9: Marginal effects (min and max). Globalization and real GDP per capita interacted.

\begin{tabular}{l|ccccc}
\hline & $(1)$ & $(2)$ & $(3)$ & $(4)$ & $(5)$ \\
& $\begin{array}{c}\text { overall } \\
\text { globalization }\end{array}$ & $\begin{array}{c}\text { overall } \\
\text { globalization }\end{array}$ & $\begin{array}{c}\text { economic } \\
\text { globalization }\end{array}$ & $\begin{array}{c}\text { social } \\
\text { globalization }\end{array}$ & $\begin{array}{c}\text { political } \\
\text { globalization }\end{array}$ \\
\hline Low income (min) & 0.513 & 0.435 & -0.311 & 1.399 & -0.193 \\
& {$[0.50]$} & {$[0.42]$} & {$[0.34]$} & {$[1.52]$} & {$[0.23]$} \\
\hline High income (max) & 1.451 & 2.068 & 1.939 & 6.392 & 1.690 \\
& {$[0.54]$} & {$[0.67]$} & {$[0.67]$} & {$[1.60]$} & {$[0.69]$} \\
\hline
\end{tabular}

Notes: Absolute value of $t$ statistics in brackets; * significant at $10 \%$; ** significant at $5 \%$; *** significant at $1 \%$ 
Table B10: Regression Results.

Dependent variable: log Price level of Government divided by price level of GDP

FGLS with heteroskedastic and autocorrelation consistent (HAC) Newey-West type standard errors.

1970-2004 (five year averages)

Cold War dummy variable included (1970-1989 period).

\begin{tabular}{|c|c|c|c|c|c|}
\hline & (1) & (2) & (3) & (4) & (5) \\
\hline $\log \mathrm{KOF}$ index of globalization (overall) & $\begin{array}{c}-0.0322 \\
{[0.80]}\end{array}$ & $\begin{array}{c}-0.0649^{*} \\
{[1.74]}\end{array}$ & & & \\
\hline log KOF index of globalization (economic) & & & $\begin{array}{c}-0.0294 \\
{[1.09]}\end{array}$ & & \\
\hline $\log$ KOF index of globalization (social) & & & & $\begin{array}{c}-0.0335 \\
{[0.86]}\end{array}$ & \\
\hline $\log$ KOF index of globalization (political) & & & & & $\begin{array}{c}-0.0381 \\
{[1.24]}\end{array}$ \\
\hline Cold War dummy variable & $\begin{array}{l}0.0186 \\
{[0.62]}\end{array}$ & $\begin{array}{c}0.1474^{* * *} \\
{[2.91]}\end{array}$ & $\begin{array}{c}0.1841^{* *} \\
{[2.33]}\end{array}$ & $\begin{array}{c}0.1519 * * * \\
{[3.10]}\end{array}$ & $\begin{array}{c}0.0995^{* *} \\
{[2.18]}\end{array}$ \\
\hline $\begin{array}{l}\text { log KOF index of globalization (overall)* } \\
\text { Cold War dummy variable }\end{array}$ & $\begin{array}{c}-0.0361 * * * \\
{[2.90]}\end{array}$ & $\begin{array}{c}-0.0221 \\
{[1.60]}\end{array}$ & & & \\
\hline $\begin{array}{l}\text { log KOF index of globalization (economic)* } \\
\text { Cold War dummy variable }\end{array}$ & & & $\begin{array}{c}-0.0224 \\
{[1.40]}\end{array}$ & & \\
\hline $\begin{array}{l}\text { log KOF index of globalization (social)* } \\
\text { Cold War dummy variable }\end{array}$ & & & & $\begin{array}{c}-0.0154 \\
{[1.26]}\end{array}$ & \\
\hline $\begin{array}{l}\text { log KOF index of globalization (political)* } \\
\text { Cold War dummy variable }\end{array}$ & & & & & $\begin{array}{c}-0.0053 \\
{[0.42]}\end{array}$ \\
\hline log real GDP per capita & & $\begin{array}{l}0.2016^{* * *} \\
{[3.17]}\end{array}$ & $\begin{array}{l}0.2173^{* * *} \\
{[2.88]}\end{array}$ & $\begin{array}{c}0.1939 * * * \\
{[3.28]}\end{array}$ & $\begin{array}{c}0.1227^{* *} \\
{[2.10]}\end{array}$ \\
\hline log Dependency ratio & & $\begin{array}{l}0.1096 \\
{[0.41]}\end{array}$ & $\begin{array}{l}0.0094 \\
{[0.03]}\end{array}$ & $\begin{array}{l}0.2288 \\
{[0.83]}\end{array}$ & $\begin{array}{l}0.3531 \\
{[1.17]}\end{array}$ \\
\hline log Population & & $\begin{array}{c}-0.0056 \\
{[0.07]}\end{array}$ & $\begin{array}{c}-0.0561 \\
{[0.44]}\end{array}$ & $\begin{array}{c}-0.0536 \\
{[0.64]}\end{array}$ & $\begin{array}{c}-0.1035 \\
{[1.31]}\end{array}$ \\
\hline Fixed country effects & Yes & Yes & Yes & Yes & Yes \\
\hline Fixed period effects & Yes & Yes & Yes & Yes & Yes \\
\hline Observations & 980 & 966 & 876 & 981 & 1121 \\
\hline Number of countries & 155 & 153 & 139 & 156 & 179 \\
\hline R-squared (within) & 0.06 & 0.11 & 0.12 & 0.10 & 0.08 \\
\hline R-squared (between) & 0.12 & 0.20 & 0.21 & 0.21 & 0.10 \\
\hline
\end{tabular}

Notes: Absolute value of $\mathrm{t}$ statistics in brackets; * significant at $10 \% ; * *$ significant at $5 \% ; * * *$ significant at $1 \%$

Table B11: Marginal effects (min and max). Cold War dummy variable included (1970-1989 period).

\begin{tabular}{l|ccccc}
\hline & $(1)$ & $(2)$ & $(3)$ & $(4)$ & $(5)$ \\
& $\begin{array}{c}\text { overall } \\
\text { globalization }\end{array}$ & $\begin{array}{c}\text { overall } \\
\text { globalization }\end{array}$ & $\begin{array}{c}\text { economic } \\
\text { globalization }\end{array}$ & $\begin{array}{c}\text { social } \\
\text { globalization }\end{array}$ & $\begin{array}{c}\text { political } \\
\text { globalization }\end{array}$ \\
\hline \multirow{2}{*}{ 1970-1989 period } & -0.064 & $-0.084 * *$ & $-0.049^{*}$ & -0.047 & -0.043 \\
& {$[1.61]$} & {$[2.37]$} & {$[1.89]$} & {$[1.34]$} & {$[1.36]$} \\
\hline \multirow{2}{*}{ 1990-2004 period } & 0.009 & -0.039 & -0.004 & -0.016 & -0.032 \\
& {$[0.21]$} & {$[0.87]$} & {$[0.10]$} & {$[0.33]$} & {$[0.90]$} \\
\hline
\end{tabular}

Notes: Absolute value of t statistics in brackets; * significant at $10 \%$; ** significant at 5\%; *** significant at $1 \%$ 
Table B12: Regression Results.

Dependent variable: log Price level of Government divided by price level of GDP

FGLS with heteroskedastic and autocorrelation consistent (HAC) Newey-West type standard errors.

1970-2004 (five year averages)

Democracy-Dictatorship dummy variable included.

\begin{tabular}{|c|c|c|c|c|c|}
\hline & (1) & (2) & (3) & (4) & (5) \\
\hline $\log \mathrm{KOF}$ index of globalization (overall) & $\begin{array}{c}-0.0368 \\
{[0.96]}\end{array}$ & $\begin{array}{c}-0.0707^{* *} \\
{[2.09]}\end{array}$ & & & \\
\hline log KOF index of globalization (economic) & & & $\begin{array}{c}-0.0481^{*} \\
{[1.85]}\end{array}$ & & \\
\hline log KOF index of globalization (social) & & & & $\begin{array}{c}-0.0461 \\
{[1.38]}\end{array}$ & \\
\hline log KOF index of globalization (political) & & & & & $\begin{array}{c}-0.0540 * \\
{[1.89]}\end{array}$ \\
\hline Democracy & $\begin{array}{c}0.0385^{*} \\
{[1.73]}\end{array}$ & $\begin{array}{c}0.0387^{*} \\
{[1.90]}\end{array}$ & $\begin{array}{c}0.0427^{*} \\
{[1.95]}\end{array}$ & $\begin{array}{c}0.0389^{*} \\
{[1.81]}\end{array}$ & $\begin{array}{c}-0.0177 \\
{[0.66]}\end{array}$ \\
\hline $\begin{array}{l}\log \text { KOF index of globalization (overall)* } \\
\text { Democracy }\end{array}$ & $\begin{array}{c}0.0535 * * * \\
{[2.82]}\end{array}$ & $\begin{array}{c}0.0400^{* *} \\
{[2.35]}\end{array}$ & & & \\
\hline $\begin{array}{l}\log \text { KOF index of globalization (economic)* } \\
\text { Democracy }\end{array}$ & & & $\begin{array}{c}0.0333 * * \\
{[2.13]}\end{array}$ & & \\
\hline $\begin{array}{l}\text { log KOF index of globalization (social)* } \\
\text { Democracy }\end{array}$ & & & & $\begin{array}{c}0.0291^{*} \\
{[1.76]}\end{array}$ & \\
\hline $\begin{array}{l}\log \text { KOF index of globalization (political)* } \\
\text { Democracy }\end{array}$ & & & & & $\begin{array}{c}0.0634 * * \\
{[2.03]}\end{array}$ \\
\hline log real GDP per capita & & $\begin{array}{c}0.1965^{* * *} \\
{[3.23]}\end{array}$ & $\begin{array}{c}0.2251^{* * *} \\
{[3.21]}\end{array}$ & $\begin{array}{l}0.1932 * * * \\
{[3.24]}\end{array}$ & $\begin{array}{c}0.1108^{*} \\
{[1.90]}\end{array}$ \\
\hline log Dependency ratio & & $\begin{array}{l}0.1968 \\
{[0.64]}\end{array}$ & $\begin{array}{l}0.0396 \\
{[0.12]}\end{array}$ & $\begin{array}{l}0.3663 \\
{[1.16]}\end{array}$ & $\begin{array}{l}0.3511 \\
{[1.08]}\end{array}$ \\
\hline $\log$ Population & & $\begin{array}{l}0.0094 \\
{[0.12]}\end{array}$ & $\begin{array}{c}-0.0561 \\
{[0.50]}\end{array}$ & $\begin{array}{c}-0.0539 \\
{[0.65]}\end{array}$ & $\begin{array}{c}-0.0677 \\
{[0.82]}\end{array}$ \\
\hline Fixed country effects & Yes & Yes & Yes & Yes & Yes \\
\hline Fixed period effects & Yes & Yes & Yes & Yes & Yes \\
\hline Observations & 952 & 941 & 864 & 949 & 1071 \\
\hline Number of countries & 154 & 152 & 139 & 154 & 176 \\
\hline R-squared (within) & 0.06 & 0.11 & 0.13 & 0.10 & 0.10 \\
\hline R-squared (between) & 0.01 & 0.21 & 0.17 & 0.21 & 0.13 \\
\hline
\end{tabular}

Notes: Absolute value of $\mathrm{t}$ statistics in brackets; * significant at $10 \% ; * *$ significant at $5 \% ; * * *$ significant at $1 \%$

Table B13: Marginal effects (min and max). Democracy-Dictatorship dummy variable included.

\begin{tabular}{l|ccccc}
\hline & $(1)$ & $(2)$ & $(3)$ & $(4)$ & $(5)$ \\
& $\begin{array}{c}\text { overall } \\
\text { globalization }\end{array}$ & $\begin{array}{c}\text { overall } \\
\text { globalization }\end{array}$ & $\begin{array}{c}\text { economic } \\
\text { globalization }\end{array}$ & $\begin{array}{c}\text { social } \\
\text { globalization }\end{array}$ & $\begin{array}{c}\text { political } \\
\text { globalization }\end{array}$ \\
\hline \multirow{2}{*}{ Democracy } & 0.026 & -0.024 & -0.009 & -0.012 & 0.020 \\
& {$[0.59]$} & {$[0.62]$} & {$[0.32]$} & {$[0.30]$} & {$[0.38]$} \\
\hline \multirow{2}{*}{ Dictatorship } & $-0.084^{* *}$ & $-0.084^{* *}$ & $-0.078^{* *}$ & $-0.072^{* *}$ & $-0.111^{* * *}$ \\
& {$[1.99]$} & {$[2.37]$} & {$[2.44]$} & {$[2.09]$} & {$[3.26]$} \\
\hline
\end{tabular}

Notes: Absolute value of $t$ statistics in brackets; * significant at $10 \%$; ** significant at $5 \%$; *** significant at $1 \%$ 
Table B14: Regression Results.

Dependent variable: log Price level of Government divided by price level of GDP

FGLS with heteroskedastic and autocorrelation consistent (HAC) Newey-West type standard errors. 1970-2004 (five year averages)

OECD country dummy variable included.

$\begin{array}{lllll}\text { (1) } & \text { (2) } & \text { (3) } & \text { (4) } & \text { (5) }\end{array}$

\begin{tabular}{|c|c|c|c|c|c|}
\hline log KOF index of globalization (overall) & $\begin{array}{c}-0.0483 \\
{[1.29]}\end{array}$ & $\begin{array}{c}-0.0753^{* *} \\
{[2.18]}\end{array}$ & & & \\
\hline $\log$ KOF index of globalization (economic) & & & $\begin{array}{c}-0.0494^{*} \\
{[1.91]}\end{array}$ & & \\
\hline $\log$ KOF index of globalization (social) & & & & $\begin{array}{c}-0.0444 \\
{[1.30]}\end{array}$ & \\
\hline log KOF index of globalization (political) & & & & & $\begin{array}{c}-0.0158 \\
{[0.48]}\end{array}$ \\
\hline OECD country & $\begin{array}{l}0.0091 \\
{[0.24]}\end{array}$ & $\begin{array}{l}0.0096 \\
{[0.28]}\end{array}$ & $\begin{array}{l}0.0300 \\
{[0.90]}\end{array}$ & $\begin{array}{l}0.0046 \\
{[0.13]}\end{array}$ & $\begin{array}{c}-0.0213 \\
{[0.65]}\end{array}$ \\
\hline $\begin{array}{l}\text { log KOF index of globalization (overall)* } \\
\text { OECD country }\end{array}$ & $\begin{array}{c}0.0484 * * * \\
{[3.37]}\end{array}$ & $\begin{array}{c}0.0386^{* *} \\
{[2.58]}\end{array}$ & & & \\
\hline $\begin{array}{l}\log \text { KOF index of globalization (economic)* } \\
\text { OECD country }\end{array}$ & & & $\begin{array}{l}0.0255 \\
{[1.65]}\end{array}$ & & \\
\hline $\begin{array}{l}\text { log KOF index of globalization (social)* } \\
\text { OECD country }\end{array}$ & & & & $\begin{array}{l}0.0522^{* * *} \\
{[2.69]}\end{array}$ & \\
\hline $\begin{array}{l}\text { log KOF index of globalization (political)* } \\
\text { OECD country }\end{array}$ & & & & & $\begin{array}{c}0.0711^{* *} \\
{[2.56]}\end{array}$ \\
\hline log real GDP per capita & & $\begin{array}{c}0.2108^{* * *} \\
{[3.46]}\end{array}$ & $\begin{array}{c}0.2247 * * * \\
{[3.14]}\end{array}$ & $\begin{array}{l}0.2040 * * * \\
{[3.46]}\end{array}$ & $\begin{array}{c}0.1191 * * \\
{[2.04]}\end{array}$ \\
\hline log Dependency ratio & & $\begin{array}{l}0.2256 \\
{[0.76]}\end{array}$ & $\begin{array}{l}0.0821 \\
{[0.26]}\end{array}$ & $\begin{array}{r}0.3663 \\
{[1.22]}\end{array}$ & $\begin{array}{l}0.3508 \\
{[1.16]}\end{array}$ \\
\hline log Population & & $\begin{array}{l}0.0157 \\
{[0.19]}\end{array}$ & $\begin{array}{c}-0.0437 \\
{[0.34]}\end{array}$ & $\begin{array}{c}-0.0051 \\
{[0.06]}\end{array}$ & $\begin{array}{c}-0.0795 \\
{[1.01]}\end{array}$ \\
\hline Fixed country effects & Yes & Yes & Yes & Yes & Yes \\
\hline Fixed period effects & Yes & Yes & Yes & Yes & Yes \\
\hline Observations & 980 & 966 & 876 & 981 & 1121 \\
\hline Number of countries & 155 & 153 & 139 & 156 & 179 \\
\hline R-squared (within) & 0.05 & 0.11 & 0.12 & 0.11 & 0.09 \\
\hline R-squared (between) & 0.00 & 0.20 & 0.25 & 0.23 & 0.16 \\
\hline
\end{tabular}

Notes: Absolute value of $\mathrm{t}$ statistics in brackets; * significant at $10 \%$; ** significant at $5 \%$; *** significant at $1 \%$

Table B15: Marginal effects ( $\min$ and $\max$ ). OECD country dummy variable included.

\begin{tabular}{l|ccccc}
\hline \multirow{2}{*}{ OECD } & $(1)$ & $(2)$ & $(3)$ & $(4)$ & $(5)$ \\
& $\begin{array}{c}\text { overall } \\
\text { globalization }\end{array}$ & $\begin{array}{c}\text { overall } \\
\text { globalization }\end{array}$ & $\begin{array}{c}\text { economic } \\
\text { globalization }\end{array}$ & $\begin{array}{c}\text { social } \\
\text { globalization }\end{array}$ & $\begin{array}{c}\text { political } \\
\text { globalization }\end{array}$ \\
\hline \multirow{2}{*}{ Non-OECD } & 0.073 & 0.022 & 0.015 & 0.087 & $0.163^{*}$ \\
& {$[1.43]$} & {$[0.41]$} & {$[0.33]$} & {$[1.43]$} & {$[1.92]$} \\
\hline
\end{tabular}

Notes: Absolute value of $\mathrm{t}$ statistics in brackets; * significant at $10 \%$; ** significant at $5 \%$; *** significant at $1 \%$ 
Table B16: Regression Results.

Dependent variable: log Price level of Government divided by price level of GDP

FGLS with heteroskedastic and autocorrelation consistent (HAC) Newey-West type standard errors.

1970-2004 (five year averages)

Globalization and real GDP per capita interacted.

\begin{tabular}{|c|c|c|c|c|c|}
\hline & (1) & (2) & (3) & (4) & (5) \\
\hline log KOF index of globalization (overall) & $\begin{array}{c}-0.0233 \\
{[0.64]}\end{array}$ & $\begin{array}{c}-0.0155 \\
{[0.44]}\end{array}$ & & & \\
\hline $\log$ KOF index of globalization (economic) & & & $\begin{array}{l}0.0085 \\
{[0.29]}\end{array}$ & & \\
\hline $\log \mathrm{KOF}$ index of globalization (social) & & & & $\begin{array}{l}0.0139 \\
{[0.37]}\end{array}$ & \\
\hline $\log$ KOF index of globalization (political) & & & & & $\begin{array}{l}-0.012 \\
{[0.45]}\end{array}$ \\
\hline log real GDP per capita & $\begin{array}{c}0.2435^{* * *} \\
{[3.32]}\end{array}$ & $\begin{array}{c}0.2524 * * * \\
{[3.31]}\end{array}$ & $\begin{array}{l}0.2676^{* * *} \\
{[2.92]}\end{array}$ & $\begin{array}{c}0.2390 * * * \\
{[3.29]}\end{array}$ & $\begin{array}{c}0.1617^{* *} \\
{[2.22]}\end{array}$ \\
\hline $\begin{array}{l}\log \text { KOF index of globalization (overall)* } \\
\text { log real GDP per capita }\end{array}$ & $\begin{array}{c}0.0498 * * * \\
{[3.31]}\end{array}$ & $\begin{array}{l}0.0545^{* * *} \\
{[3.40]}\end{array}$ & & & \\
\hline $\begin{array}{l}\log \text { KOF index of globalization (economic)* } \\
\text { log real GDP per capita }\end{array}$ & & & $\begin{array}{c}0.0522 * * \\
{[2.45]}\end{array}$ & & \\
\hline $\begin{array}{l}\log \text { KOF index of globalization (social)* } \\
\text { log real GDP per capita }\end{array}$ & & & & $\begin{array}{l}0.0555^{* * *} \\
\quad[3.30]\end{array}$ & \\
\hline $\begin{array}{l}\log \text { KOF index of globalization (political)* } \\
\text { log real GDP per capita }\end{array}$ & & & & & $\begin{array}{c}0.0409^{*} \\
{[1.95]}\end{array}$ \\
\hline log Dependency ratio & & $\begin{array}{c}-0.0549 \\
{[0.21]}\end{array}$ & $\begin{array}{c}-0.1339 \\
{[0.51]}\end{array}$ & $\begin{array}{l}0.1349 \\
{[0.48]}\end{array}$ & $\begin{array}{c}0.26 \\
{[0.90]}\end{array}$ \\
\hline log Population & & $\begin{array}{l}0.0643 \\
{[0.78]}\end{array}$ & $\begin{array}{l}0.0572 \\
{[0.41]}\end{array}$ & $\begin{array}{l}0.0235 \\
{[0.28]}\end{array}$ & $\begin{array}{c}-0.0798 \\
{[1.04]}\end{array}$ \\
\hline Fixed country effects & Yes & Yes & Yes & Yes & Yes \\
\hline Fixed period effects & Yes & Yes & Yes & Yes & Yes \\
\hline Observations & 980 & 966 & 876 & 981 & 1121 \\
\hline Number of countries & 155 & 153 & 139 & 156 & 179 \\
\hline R-squared (within) & 0.13 & 0.13 & 0.14 & 0.12 & 0.09 \\
\hline R-squared (between) & 0.23 & 0.16 & 0.19 & 0.22 & 0.16 \\
\hline
\end{tabular}

Notes: Absolute value of $\mathrm{t}$ statistics in brackets; $*$ significant at $10 \% ; * *$ significant at $5 \%$; $* *$ significant at $1 \%$

Table B17: Marginal effects (min and max). Globalization and real GDP per capita interacted.

\begin{tabular}{l|ccccc}
\hline & $(1)$ & $(2)$ & $(3)$ & $(4)$ & $(5)$ \\
& overall & $\begin{array}{c}\text { overall } \\
\text { globalization }\end{array}$ & $\begin{array}{c}\text { economic } \\
\text { globalization }\end{array}$ & $\begin{array}{c}\text { globalization } \\
\text { globalization }\end{array}$ & $\begin{array}{c}\text { political } \\
\text { globalization }\end{array}$ \\
\hline \multirow{2}{*}{ Low income (min) } & $-0.172^{* * *}$ & $-0.179^{* * * *}$ & $-0.148^{* * *}$ & $-0.152^{* * *}$ & $-0.134^{* *}$ \\
& {$[3.77]$} & {$[3.61]$} & {$[2.72]$} & {$[3.52]$} & {$[1.98]$} \\
\hline \multirow{2}{*}{ High income (max) } & 0.092 & $0.111^{*}$ & $0.130^{*}$ & $0.143 * *$ & 0.083 \\
& {$[1.55]$} & {$[1.88]$} & {$[1.86]$} & {$[2.19]$} & {$[1.49]$} \\
\hline
\end{tabular}

Notes: Absolute value of $\mathrm{t}$ statistics in brackets; * significant at $10 \%$; * significant at $5 \%$; *** significant at $1 \%$ 
Table B18: Regression Results.

Dependent variable: Price level of Government divided by prive level of GDP

FGLS with heteroskedastic and autocorrelation consistent (HAC) Newey-West type standard errors. 1970-2004 (five year averages)

\begin{tabular}{|c|c|c|c|c|c|}
\hline & (1) & (2) & (3) & (4) & (5) \\
\hline KOF index of globalization (overall) & $\begin{array}{c}0.0032 \\
{[1.61]}\end{array}$ & $\begin{array}{c}0.0002 \\
{[0.09]}\end{array}$ & & & \\
\hline KOF index of globalization (economic) & & & $\begin{array}{l}0.0007 \\
{[0.57]}\end{array}$ & & \\
\hline KOF index of globalization (social) & & & & $\begin{array}{c}0.0032 * * \\
{[2.07]}\end{array}$ & \\
\hline KOF index of globalization (political) & & & & & $\begin{array}{c}-0.0023 \\
{[1.46]}\end{array}$ \\
\hline real GDP per capita & & $\begin{array}{c}1 \times 10^{-5} * * * \\
{[4.05]}\end{array}$ & $\begin{array}{c}1 \times 10^{-5} * * * \\
{[3.99]}\end{array}$ & $\begin{array}{c}1 \times 10^{-5} * * * \\
{[3.94]}\end{array}$ & $\begin{array}{c}1 \times 10^{-5 * * *} \\
{[4.30]}\end{array}$ \\
\hline Dependency ratio & & $\begin{array}{c}0.0048 \\
{[1.15]}\end{array}$ & $\begin{array}{c}0.0044 \\
{[0.98]}\end{array}$ & $\begin{array}{c}0.0044 \\
{[1.08]}\end{array}$ & $\begin{array}{c}0.0064 \\
{[1.56]}\end{array}$ \\
\hline Population & & $\begin{array}{c}5 \times 10^{-7} * * \\
{[2.42]}\end{array}$ & $\begin{array}{c}5 \times 10^{-7} * * \\
{[2.56]}\end{array}$ & $\begin{array}{c}4 \times 10^{-7} * * \\
{[2.21]}\end{array}$ & $\begin{array}{c}6 \times 10^{-7} * * * \\
{[2.78]}\end{array}$ \\
\hline Fixed country effects & Yes & Yes & Yes & Yes & Yes \\
\hline Fixed period effects & Yes & Yes & Yes & Yes & Yes \\
\hline Observations & 980 & 966 & 876 & 981 & 1121 \\
\hline Number of countries & 155 & 153 & 139 & 156 & 179 \\
\hline R-squared (within) & 0.03 & 0.08 & 0.10 & 0.08 & 0.08 \\
\hline R-squared (between) & 0.21 & 0.10 & 0.00 & 0.15 & 0.03 \\
\hline
\end{tabular}

Notes: Absolute value of $t$ statistics in brackets; $*$ significant at $10 \% ; * *$ significant at $5 \%$; *** significant at $1 \%$ 
Table B19: Regression Results.

Dependent variable: Price level of Government divided by price level of GDP

FGLS with heteroskedastic and autocorrelation consistent (HAC) Newey-West type standard errors.

1970-2004 (five year averages)

Cold War dummy variable included (1970-1989 period).

\begin{tabular}{|c|c|c|c|c|c|}
\hline & (1) & (2) & (3) & (4) & (5) \\
\hline KOF index of globalization (overall) & $\begin{array}{l}0.0151 \\
{[0.47]}\end{array}$ & $\begin{array}{l}0.0021 \\
{[0.07]}\end{array}$ & & & \\
\hline KOF index of globalization (economic) & & & $\begin{array}{l}0.0138 \\
{[0.58]}\end{array}$ & & \\
\hline KOF index of globalization (social) & & & & $\begin{array}{c}0.0656^{* *} \\
{[2.05]}\end{array}$ & \\
\hline KOF index of globalization (political) & & & & & $\begin{array}{c}-0.0609 \\
{[1.61]}\end{array}$ \\
\hline Cold War dummy variable & $\begin{array}{c}0.0476^{*} \\
{[1.70]}\end{array}$ & $\begin{array}{c}0.0906 * * * \\
{[3.17]}\end{array}$ & $\begin{array}{c}0.1281^{* *} \\
{[2.52]}\end{array}$ & $\begin{array}{c}0.0904 * * * \\
{[3.59]}\end{array}$ & $\begin{array}{c}0.0735^{* * *} \\
{[3.45]}\end{array}$ \\
\hline $\begin{array}{l}\text { KOF index of globalization (overall)* } \\
\text { Cold War dummy variable }\end{array}$ & $\begin{array}{c}-0.0302 * * * \\
{[3.98]}\end{array}$ & $\begin{array}{c}-0.0009 \\
{[0.07]}\end{array}$ & & & \\
\hline $\begin{array}{l}\text { KOF index of globalization (economic)* } \\
\text { Cold War dummy variable }\end{array}$ & & & $\begin{array}{l}0.0018 \\
{[0.11]}\end{array}$ & & \\
\hline $\begin{array}{l}\text { KOF index of globalization (social)* } \\
\text { Cold War dummy variable }\end{array}$ & & & & $\begin{array}{l}-0.003 \\
{[0.36]}\end{array}$ & \\
\hline $\begin{array}{l}\text { KOF index of globalization (political)* } \\
\text { Cold War dummy variable }\end{array}$ & & & & & $\begin{array}{c}-0.0061 \\
{[0.62]}\end{array}$ \\
\hline real GDP per capita & & $\begin{array}{c}1 \times 10^{-5 * * *} \\
{[2.89]}\end{array}$ & $\begin{array}{c}2 \times 10^{-5 * * *} \\
{[2.64]}\end{array}$ & $\begin{array}{c}1 \times 10^{-5 * * *} \\
{[3.37]}\end{array}$ & $\begin{array}{c}1 \times 10^{-5 * * *} \\
{[3.63]}\end{array}$ \\
\hline Dependency ratio & & $\begin{array}{l}0.0048 \\
{[1.13]}\end{array}$ & $\begin{array}{l}0.0045 \\
{[0.95]}\end{array}$ & $\begin{array}{l}0.0043 \\
{[1.04]}\end{array}$ & $\begin{array}{c}0.0066^{*} \\
{[1.66]}\end{array}$ \\
\hline Population & & $\begin{array}{c}5 \times 10^{-7} * * * \\
{[2.70]}\end{array}$ & $\begin{array}{c}5 \times 10^{-7} * * * \\
{[2.93]}\end{array}$ & $\begin{array}{c}4 \times 10^{-7 * * *} \\
{[2.35]}\end{array}$ & $\begin{array}{c}6 \times 10^{-7} * * \\
{[2.49]}\end{array}$ \\
\hline Fixed country effects & Yes & Yes & Yes & Yes & Yes \\
\hline Fixed period effects & Yes & Yes & Yes & Yes & Yes \\
\hline Observations & 980 & 966 & 876 & 981 & 1121 \\
\hline Number of countries & 155 & 153 & 139 & 156 & 179 \\
\hline R-squared (within) & 0.05 & 0.08 & 0.10 & 0.08 & 0.08 \\
\hline R-squared (between) & 0.00 & 0.09 & 0.12 & 0.14 & 0.03 \\
\hline
\end{tabular}

Notes: Absolute value of $\mathrm{t}$ statistics in brackets; * significant at $10 \% ; * *$ significant at $5 \% ; * * *$ significant at $1 \%$

Table B20: Marginal effects (min and max). Cold War dummy variable included (1970-1989 period).

\begin{tabular}{l|ccccc}
\hline & $(1)$ & $(2)$ & $(3)$ & $(4)$ & $(5)$ \\
& $\begin{array}{c}\text { overall } \\
\text { globalization }\end{array}$ & $\begin{array}{c}\text { overall } \\
\text { globalization }\end{array}$ & $\begin{array}{c}\text { economic } \\
\text { globalization }\end{array}$ & $\begin{array}{c}\text { social } \\
\text { globalization }\end{array}$ & $\begin{array}{c}\text { political } \\
\text { globalization }\end{array}$ \\
\hline \multirow{2}{*}{ 1970-1989 period } & -0.011 & 0.001 & 0.015 & $0.069^{* *}$ & $-0.066^{*}$ \\
& {$[0.33]$} & {$[0.04]$} & {$[0.55]$} & {$[2.03]$} & {$[1.77]$} \\
\hline \multirow{2}{*}{ 1990-2004 period } & 0.050 & 0.003 & 0.012 & $0.063^{*}$ & -0.054 \\
& {$[1.56]$} & {$[0.10]$} & {$[0.40]$} & {$[1.96]$} & {$[1.30]$} \\
\hline
\end{tabular}

Notes: Absolute value of $t$ statistics in brackets; * significant at $10 \%$; ** significant at $5 \%$; *** significant at $1 \%$ 
Table B21: Regression Results.

Dependent variable: Price level of Government divided by price level of GDP

FGLS with heteroskedastic and autocorrelation consistent (HAC) Newey-West type standard errors.

1970-2004 (five year averages)

Democracy-Dictatorship dummy variable included.

\begin{tabular}{|c|c|c|c|c|c|}
\hline & (1) & (2) & (3) & (4) & (5) \\
\hline KOF index of globalization (overall) & $\begin{array}{l}0.0188 \\
{[0.54]}\end{array}$ & $\begin{array}{c}-0.0188 \\
{[0.55]}\end{array}$ & & & \\
\hline KOF index of globalization (economic) & & & $\begin{array}{c}-0.0017 \\
{[0.06]}\end{array}$ & & \\
\hline KOF index of globalization (social) & & & & $\begin{array}{c}0.0517^{*} \\
{[1.77]}\end{array}$ & \\
\hline KOF index of globalization (political) & & & & & $\begin{array}{c}-0.0606 \\
{[1.54]}\end{array}$ \\
\hline Democracy & $\begin{array}{l}0.0294 \\
{[1.30]}\end{array}$ & $\begin{array}{c}0.0401^{*} \\
{[1.71]}\end{array}$ & $\begin{array}{c}0.0453^{*} \\
{[1.76]}\end{array}$ & $\begin{array}{l}0.0351 \\
{[1.57]}\end{array}$ & $\begin{array}{c}-0.0086 \\
{[0.38]}\end{array}$ \\
\hline $\begin{array}{l}\text { KOF index of globalization (overall)* } \\
\text { Democracy }\end{array}$ & $\begin{array}{c}0.0539 * * \\
{[2.52]}\end{array}$ & $\begin{array}{l}0.031 \\
{[1.60]}\end{array}$ & & & \\
\hline $\begin{array}{l}\text { log KOF index of globalization (economic)* } \\
\text { Democracy }\end{array}$ & & & $\begin{array}{l}0.0267 \\
{[1.39]}\end{array}$ & & \\
\hline $\begin{array}{l}\text { KOF index of globalization (social)* } \\
\text { Democracy }\end{array}$ & & & & $\begin{array}{l}0.013 \\
{[0.81]}\end{array}$ & \\
\hline $\begin{array}{l}\text { KOF index of globalization (political)* } \\
\text { Democracy }\end{array}$ & & & & & $\begin{array}{c}0.0518^{* *} \\
{[2.19]}\end{array}$ \\
\hline real GDP per capita & & $\begin{array}{c}1 \times 10^{-5 * * *} \\
{[3.71]}\end{array}$ & $\begin{array}{c}1 \times 10^{-5 * * *} \\
{[3.78]}\end{array}$ & $\begin{array}{c}1 \times 10^{-5 * * *} \\
{[3.49]}\end{array}$ & $\begin{array}{c}1 \times 10^{-5 * * * *} \\
{[4.15]}\end{array}$ \\
\hline Dependency ratio & & $\begin{array}{r}0.0058 \\
{[1.27]}\end{array}$ & $\begin{array}{r}0.0047 \\
{[1.02]}\end{array}$ & $\begin{array}{l}0.0057 \\
{[1.31]}\end{array}$ & $\begin{array}{l}0.0065 \\
{[1.49]}\end{array}$ \\
\hline Population & & $\begin{array}{c}6 \times 10^{-5 * *} \\
{[2.46]}\end{array}$ & $\begin{array}{c}6 \times 10^{-7 * * * *} \\
{[2.67]}\end{array}$ & $\begin{array}{c}5 \times 10^{-7 * *} \\
{[2.44]}\end{array}$ & $\begin{array}{c}6 \times 10^{-7} * * \\
{[2.44]}\end{array}$ \\
\hline Fixed country effects & Yes & Yes & Yes & Yes & Yes \\
\hline Fixed period effects & Yes & Yes & Yes & Yes & Yes \\
\hline Observations & 952 & 941 & 864 & 949 & 1071 \\
\hline Number of countries & 154 & 152 & 139 & 154 & 176 \\
\hline R-squared (within) & 0.05 & 0.09 & 0.11 & 0.09 & 0.10 \\
\hline R-squared (between) & 0.05 & 0.05 & 0.07 & 0.12 & 0.03 \\
\hline
\end{tabular}

Notes: Absolute value of $\mathrm{t}$ statistics in brackets; * significant at $10 \% ; * *$ significant at $5 \% ; * * *$ significant at $1 \%$

Table B22: Marginal effects (min and max). Democracy-Dictatorship dummy variable included.

\begin{tabular}{l|ccccc}
\hline & $(1)$ & $(2)$ & $(3)$ & $(4)$ & $(5)$ \\
& $\begin{array}{c}\text { overall } \\
\text { globalization }\end{array}$ & $\begin{array}{c}\text { overall } \\
\text { globalization }\end{array}$ & $\begin{array}{c}\text { economic } \\
\text { globalization }\end{array}$ & $\begin{array}{c}\text { social } \\
\text { globalization }\end{array}$ & $\begin{array}{c}\text { political } \\
\text { globalization }\end{array}$ \\
\hline \multirow{2}{*}{ Democracy } & $0.082^{* *}$ & 0.017 & 0.030 & $0.067^{* *}$ & $-1 \times 10^{-5}$ \\
& {$[2.33]$} & {$[0.57]$} & {$[1.09]$} & {$[2.02]$} & {$[0.00]$} \\
\hline \multirow{2}{*}{ Dictatorship } & -0.030 & -0.047 & -0.026 & 0.040 & $-0.107^{* *}$ \\
& {$[0.66]$} & {$[1.03]$} & {$[1.08]$} & {$[1.19]$} & {$[2.16]$} \\
\hline
\end{tabular}

Notes: Absolute value of $t$ statistics in brackets; * significant at $10 \%$; ** significant at $5 \%$; *** significant at $1 \%$ 
Table B23: Regression Results.

Dependent variable: Price level of Government divided by price level of GDP

FGLS with heteroskedastic and autocorrelation consistent (HAC) Newey-West type standard errors. 1970-2004 (five year averages)

OECD country dummy variable included.

$\begin{array}{lllll}\text { (1) } & \text { (2) } & \text { (3) } & \text { (4) }\end{array}$

\begin{tabular}{lll}
\hline KOF index of globalization (overall) & 0.0192 & -0.008 \\
& {$[0.61]$} & {$[0.27]$}
\end{tabular}

KOF index of globalization (economic)

0.0119
$[0.46]$

KOF index of globalization (social)

$0.0607^{*}$

KOF index of globalization (political)

OECD country
KOF index of globalization (overall)*
OECD country

$[1.89]$

KOF index of globalization (economic)*

OECD country

KOF index of globalization (social)*

OECD country

$-0.004$

[0.29]

KOF index of globalization (political)*

OECD country

$\begin{array}{cc}0.0041 & 0.0401 \\ {[0.12]} & {[1.42]} \\ 0.0378^{* * *} & 0.0026 \\ {[3.19]} & {[0.21]}\end{array}$

real GDP per capita

$2 \times 10^{-5 * * * *}$

$2 \times 10^{-5 * * *}$

$0.0328 * *$

$-0.0579$

[1.52]

[0.09]

Dependency ratio

Population

[3.59]

[3.56]

$[2.02]$

Fixed country effects

0.0047

0.0034

$1 \times 10^{-5 * * *}$

$1 \times 10^{-5 * * *}$

Fixed period effects

[1.14]

$5 \times 10^{-7} * *$

[0.78]

$5 \times 10^{-7} * *$

[3.37]

[4.11]

0.004

0.0064

[2.53]

[1.02]

$4 \times 10^{-7} * *$

[1.56]

Observations

Yes

[2.58]

[2.32]

$7 \times 10^{-7} * * *$

Number of countries

R-squared (within)

Yes

Yes

Yes

[2.89]

R-squared (between)

$980 \quad 966$

Yes

Yes

Yes

Yes

876

Yes

Yes

155

153

139

981

1121

0.04

0.08

0.10

156

121

0.14

0.10

0.14

0.08

179

Notes: Absolute value of $t$ statistics in brackets; * significant at $10 \%$;* significant at $5 \% ; * * *$ significant at $1 \%$

Table B24: Marginal effects ( $\min$ and $\max$ ). OECD country dummy variable included.

\begin{tabular}{l|ccccc}
\hline \multirow{2}{*}{ OECD } & $(1)$ & $(2)$ & $(3)$ & $(4)$ & $(5)$ \\
& $\begin{array}{c}\text { overall } \\
\text { globalization }\end{array}$ & $\begin{array}{c}\text { overall } \\
\text { globalization }\end{array}$ & $\begin{array}{c}\text { economic } \\
\text { globalization }\end{array}$ & $\begin{array}{c}\text { social } \\
\text { globalization }\end{array}$ & $\begin{array}{c}\text { political } \\
\text { globalization }\end{array}$ \\
\hline \multirow{2}{*}{ Non-OECD } & $0.114^{* * *}$ & -0.001 & $-0-014$ & 0.051 & 0.024 \\
& {$[3.24]$} & {$[0.04]$} & {$[0.43]$} & {$[1.41]$} & {$[0.66]$} \\
\hline
\end{tabular}

Notes: Absolute value of $\mathrm{t}$ statistics in brackets; * significant at $10 \%$; ** significant at $5 \%$; *** significant at $1 \%$ 
Table B25: Regression Results.

Dependent variable: Price level of Government divided by price level of GDP

FGLS with heteroskedastic and autocorrelation consistent (HAC) Newey-West type standard errors. 1970-2004 (five year averages)

Globalization and real GDP per capita interacted.

\begin{tabular}{|c|c|c|c|c|c|}
\hline & (1) & $(2)$ & (3) & (4) & $(5)$ \\
\hline KOF index of globalization (overall) & $\begin{array}{c}0.012 \\
{[0.42]}\end{array}$ & $\begin{array}{l}0.0024 \\
{[0.08]}\end{array}$ & & & \\
\hline KOF index of globalization (economic) & & & $\begin{array}{l}0.0095 \\
{[0.40]}\end{array}$ & & \\
\hline KOF index of globalization (social) & & & & $\begin{array}{c}0.0543 * \\
{[1.76]}\end{array}$ & \\
\hline KOF index of globalization (political) & & & & & $\begin{array}{l}-0.056 \\
{[1.44]}\end{array}$ \\
\hline real GDP per capita & $\begin{array}{c}0.1466^{* * *} \\
{[3.56]}\end{array}$ & $\begin{array}{c}0.1331^{* * *} \\
{[3.73]}\end{array}$ & $\begin{array}{c}0.1571^{* * *} \\
{[3.32]}\end{array}$ & $\begin{array}{c}0.1481^{* * *} \\
{[3.37]}\end{array}$ & $\begin{array}{c}0.0754 * * * \\
{[3.28]}\end{array}$ \\
\hline $\begin{array}{l}\text { KOF index of globalization (overall)* } \\
\text { real GDP per capita }\end{array}$ & $\begin{array}{c}-0.0240 * * \\
{[2.06]}\end{array}$ & $\begin{array}{c}-0.0171 \\
{[1.59]}\end{array}$ & & & \\
\hline $\begin{array}{l}\text { KOF index of globalization (economic)* } \\
\text { real GDP per capita }\end{array}$ & & & $\begin{array}{c}-0.0254 \\
{[1.61]}\end{array}$ & & \\
\hline $\begin{array}{l}\text { KOF index of globalization (social)* } \\
\text { real GDP per capita }\end{array}$ & & & & $\begin{array}{c}-0.0332 * * \\
{[2.12]}\end{array}$ & \\
\hline $\begin{array}{l}\text { KOF index of globalization (political)* } \\
\text { real GDP per capita }\end{array}$ & & & & & $\begin{array}{l}0.0094 \\
{[0.99]}\end{array}$ \\
\hline Dependency ratio & & $\begin{array}{l}0.0035 \\
{[0.83]}\end{array}$ & $\begin{array}{l}0.0028 \\
{[0.62]}\end{array}$ & $\begin{array}{l}0.0028 \\
{[0.71]}\end{array}$ & $\begin{array}{l}0.0069 \\
{[1.63]}\end{array}$ \\
\hline Population & & $\begin{array}{c}5 \times 10^{-7} * * \\
{[2.24]}\end{array}$ & $\begin{array}{c}5 \times 10^{-7 * * *} \\
{[2.42]}\end{array}$ & $\begin{array}{c}3 \times 10^{-7} * \\
{[1.85]}\end{array}$ & $\begin{array}{c}6 \times 10^{-7 * * *} \\
{[2.82]}\end{array}$ \\
\hline Fixed country effects & Yes & Yes & Yes & Yes & Yes \\
\hline Fixed period effects & Yes & Yes & Yes & Yes & Yes \\
\hline Observations & 980 & 966 & 876 & 981 & 1121 \\
\hline Number of countries & 155 & 153 & 139 & 156 & 179 \\
\hline R-squared (within) & 0.08 & 0.08 & 0.10 & 0.09 & 0.08 \\
\hline R-squared (between) & 0.18 & 0.12 & 0.14 & 0.16 & 0.03 \\
\hline
\end{tabular}

Notes: Absolute value of $\mathrm{t}$ statistics in brackets; $*$ significant at $10 \% ; * *$ significant at $5 \%$; $* *$ significant at $1 \%$

Table B26: Marginal effects (min and max). Globalization and real GDP per capita interacted.

\begin{tabular}{l|ccccc}
\hline & $(1)$ & $(2)$ & $(3)$ & $(4)$ & $(5)$ \\
& $\begin{array}{c}\text { overall } \\
\text { globalization }\end{array}$ & $\begin{array}{c}\text { overall } \\
\text { globalization }\end{array}$ & $\begin{array}{c}\text { economic } \\
\text { globalization }\end{array}$ & $\begin{array}{c}\text { social } \\
\text { globalization }\end{array}$ & $\begin{array}{c}\text { political } \\
\text { globalization }\end{array}$ \\
\hline Low income (min) & 0.932 & 0.016 & 0.030 & $0.081^{* *}$ & -0.064 \\
& {$[1.01]$} & {$[0.52]$} & {$[1.20]$} & {$[2.34]$} & {$[1.54]$} \\
\hline High income (max) & $-0.142^{*}$ & $-0-108$ & -0.154 & -0.159 & 0.004 \\
& {$[1.86]$} & {$[1.50]$} & {$[1.43]$} & {$[1.56]$} & {$[0.07]$} \\
\hline
\end{tabular}

Notes: Absolute value of $\mathrm{t}$ statistics in brackets; * significant at $10 \%$; ** significant at $5 \%$; *** significant at $1 \%$ 
Figure B1: log Size of government and log overall KOF index of globalization 1970-2004 (five year averages).

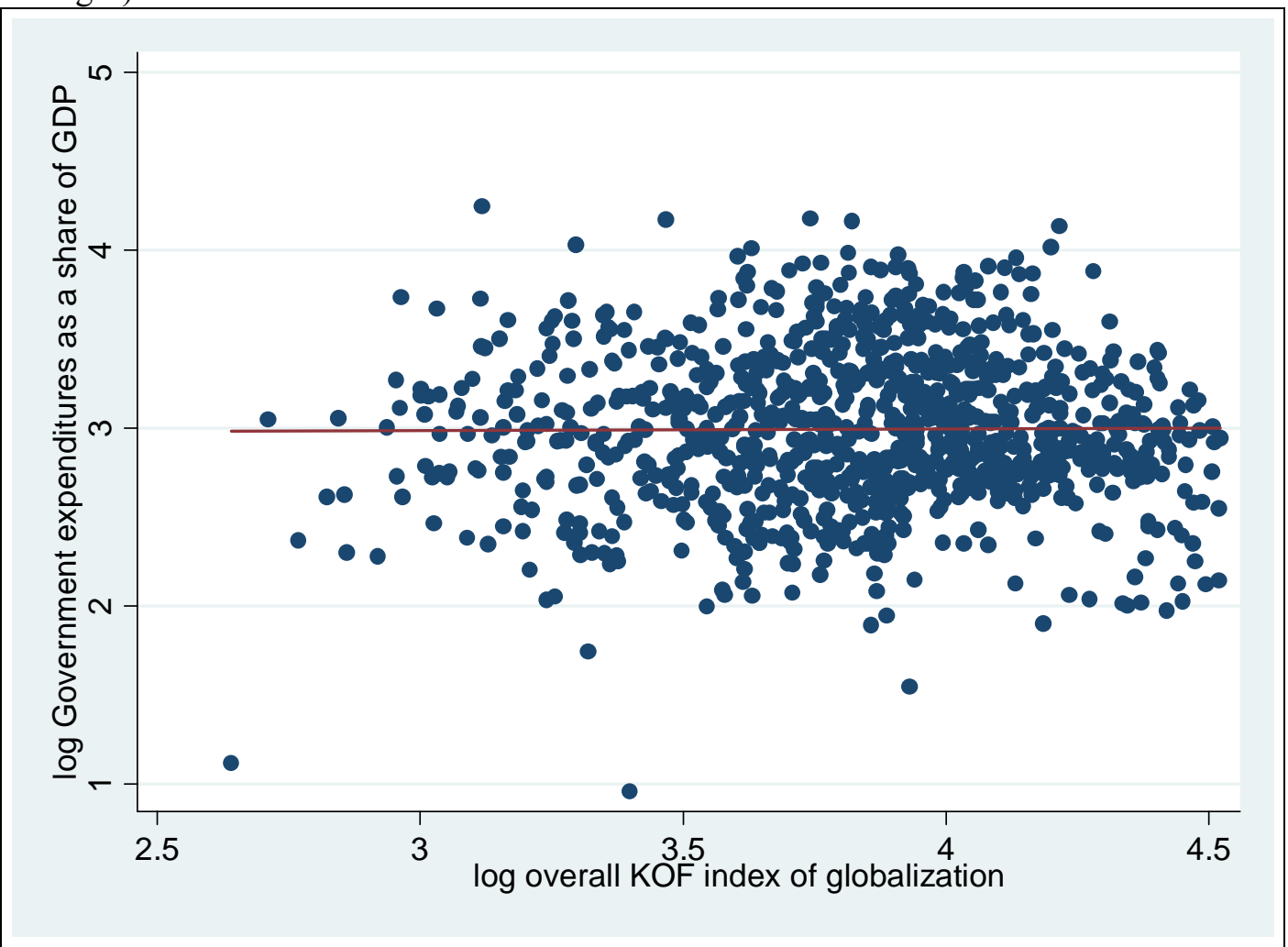

Correlation coefficient: 0.01. Source: Penn World Tables 6.2 and Dreher (2006) and Dreher et al. (2008a)

Figure B2: $\log$ Size of government and $\log$ KOF index of economic globalization 1970-2004 (five year averages).

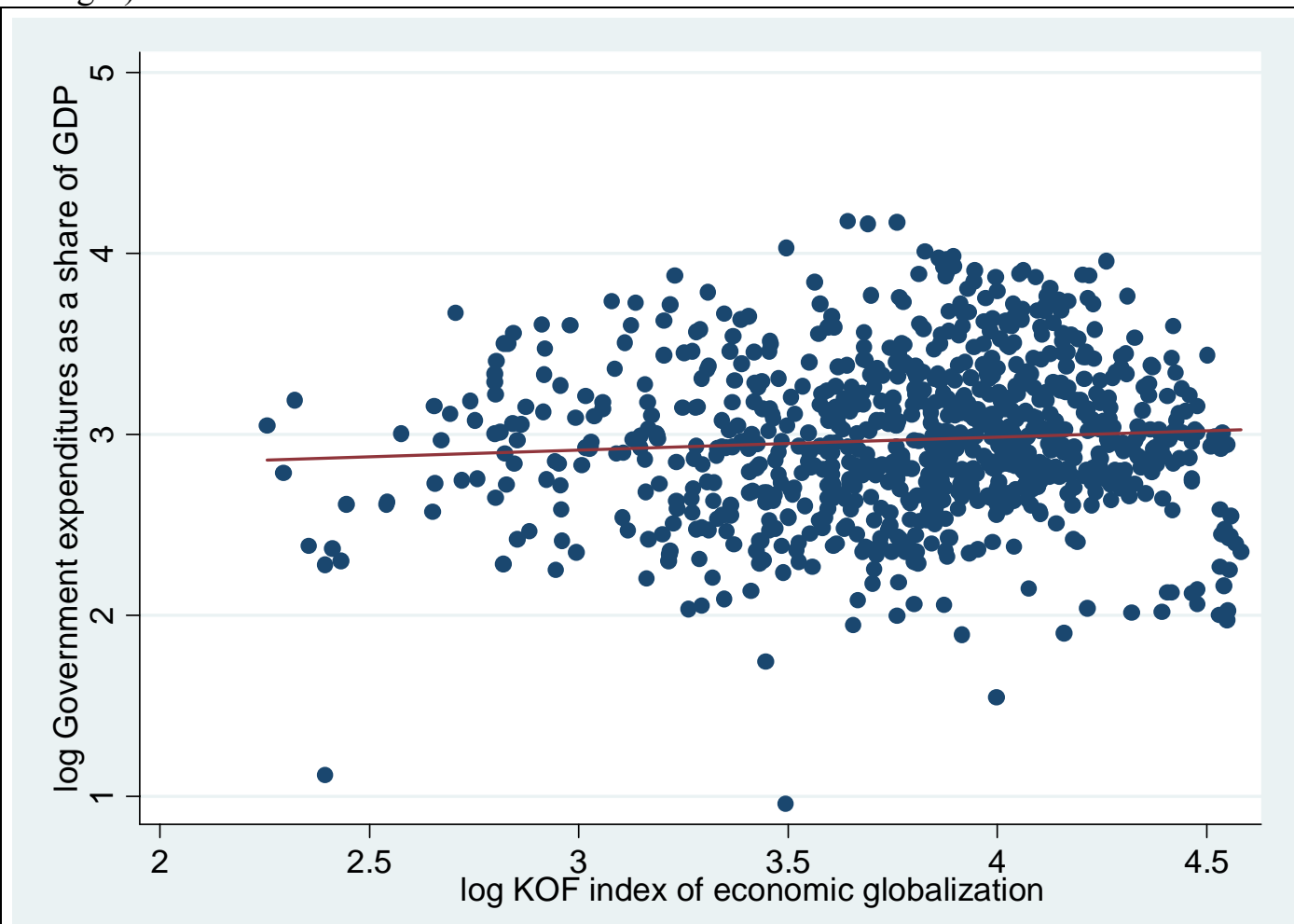

Correlation coefficient: 0.07. Source: Penn World Tables 6.2 and Dreher (2006) and Dreher et al. (2008a) 
Figure B3: $\log$ Size of government and $\log$ KOF index of social globalization 1970-2004 (five year averages).

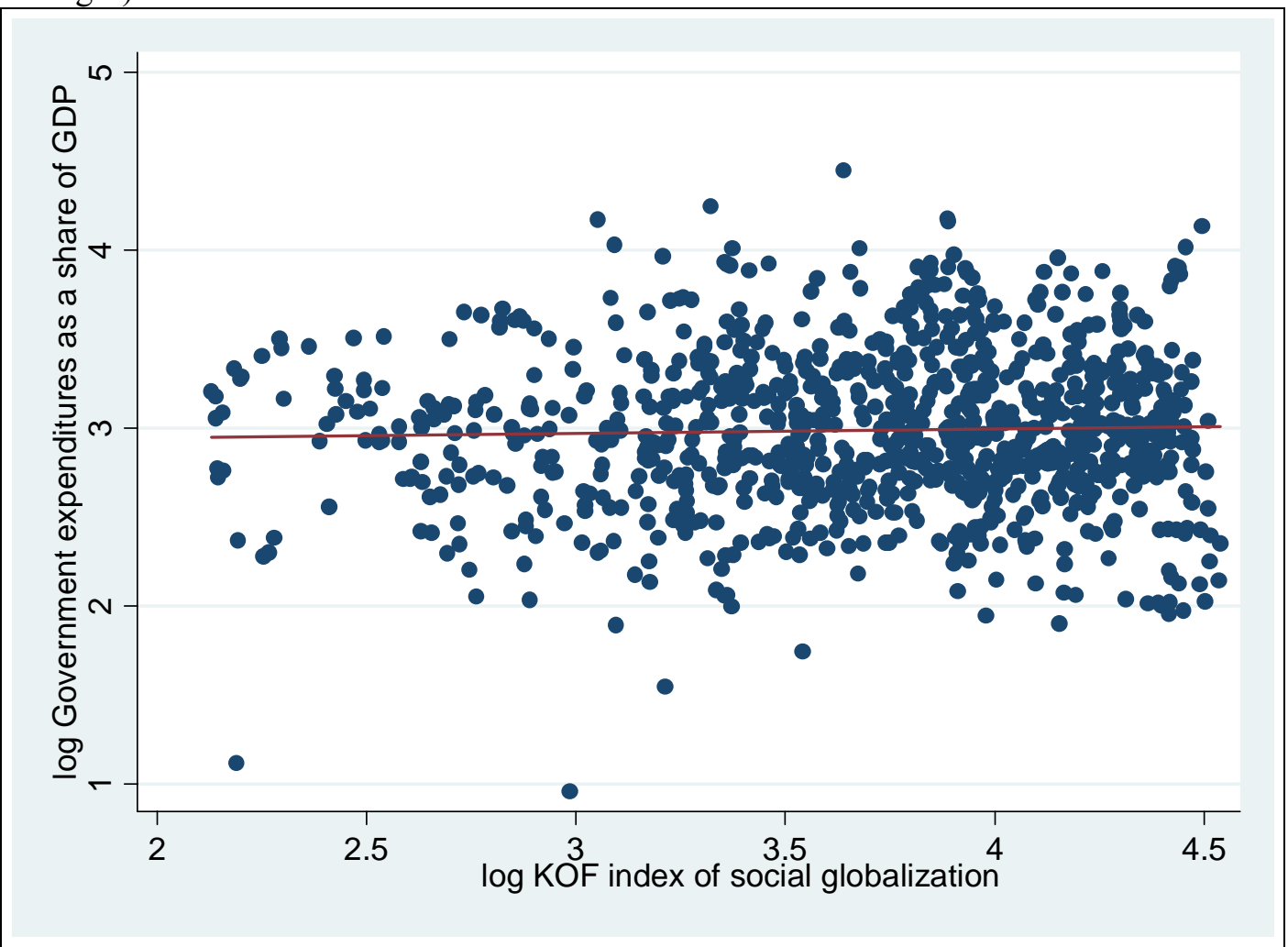

Correlation coefficient: 0.03. Source: Penn World Tables 6.2 and Dreher (2006) and Dreher et al. (2008a)

Figure B4: $\log$ Size of government and log KOF index of political globalization 1970-2004 (five year averages).

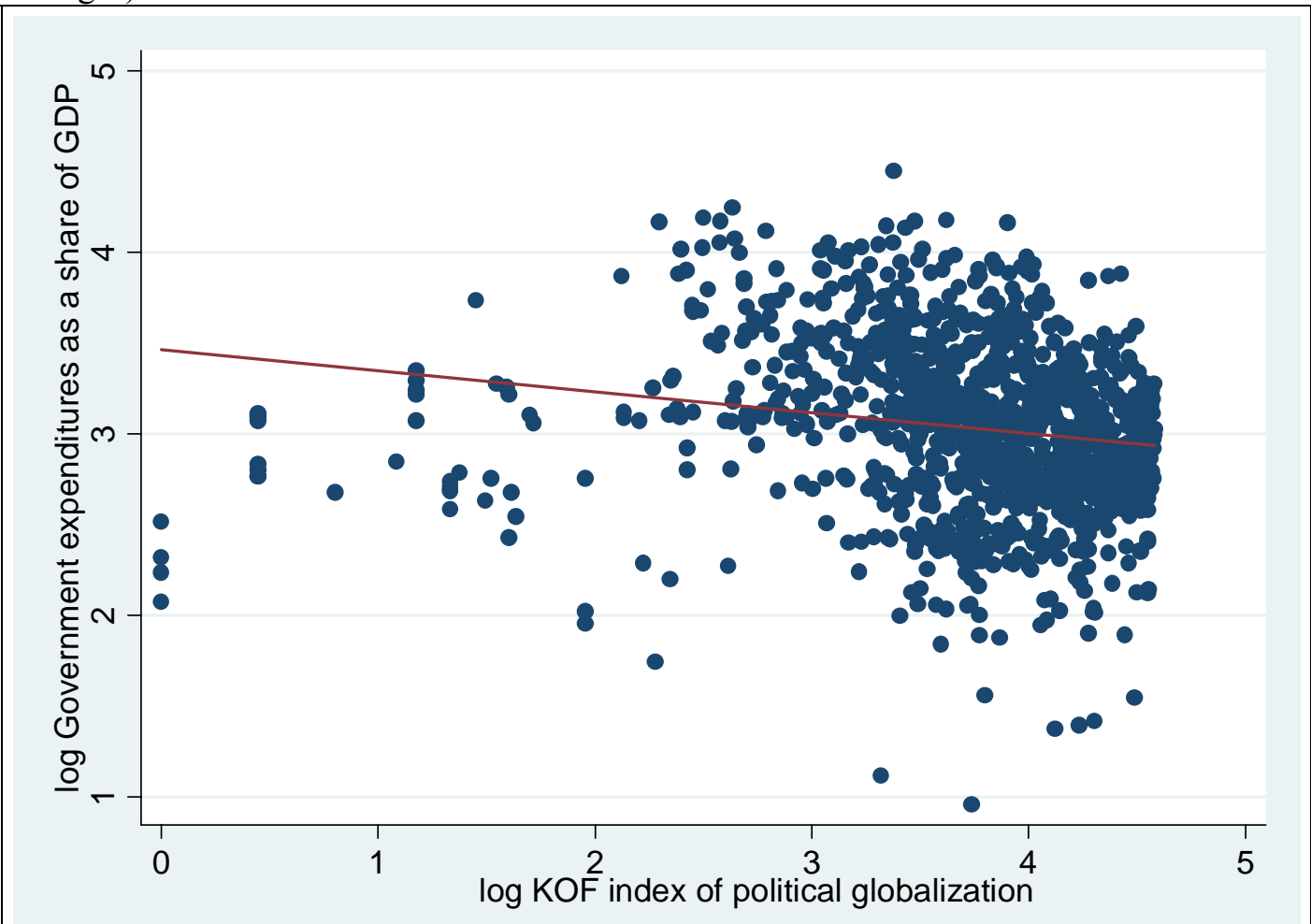

Correlation coefficient: -0.18. Source: Penn World Tables 6.2 and Dreher (2006) and Dreher et al. (2008a) 
Figure B5: $\log$ Price level of Government divided by price level of GDP and log overall KOF index of globalization 1970-2004 (five year averages).

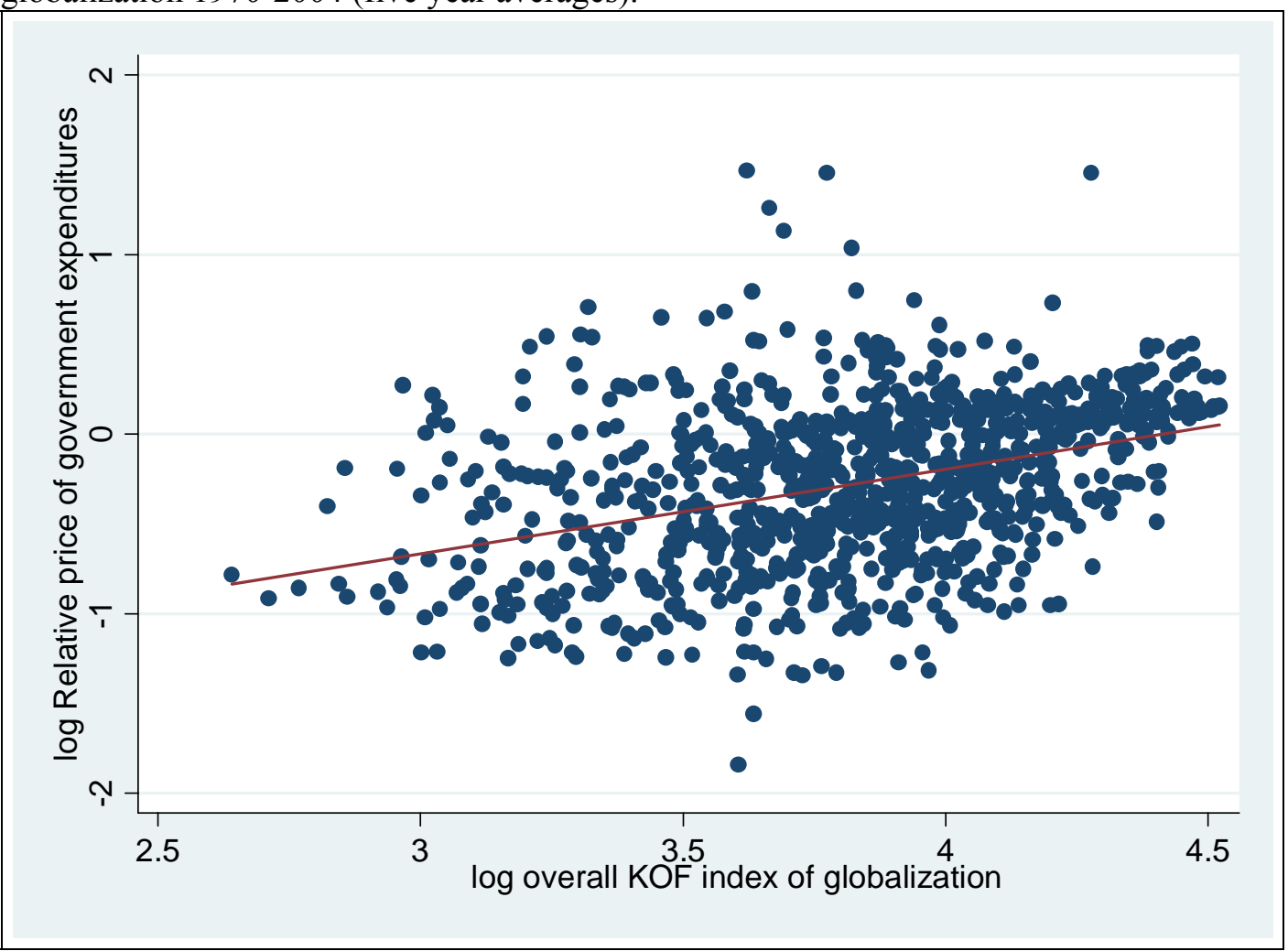

Correlation coefficient: 0.38. Source: Penn World Tables 6.2 and Dreher (2006) and Dreher et al. (2008a)

Figure B6: log Price level of Government divided by price level of GDP and log KOF index of economic globalization 1970-2004 (five year averages).

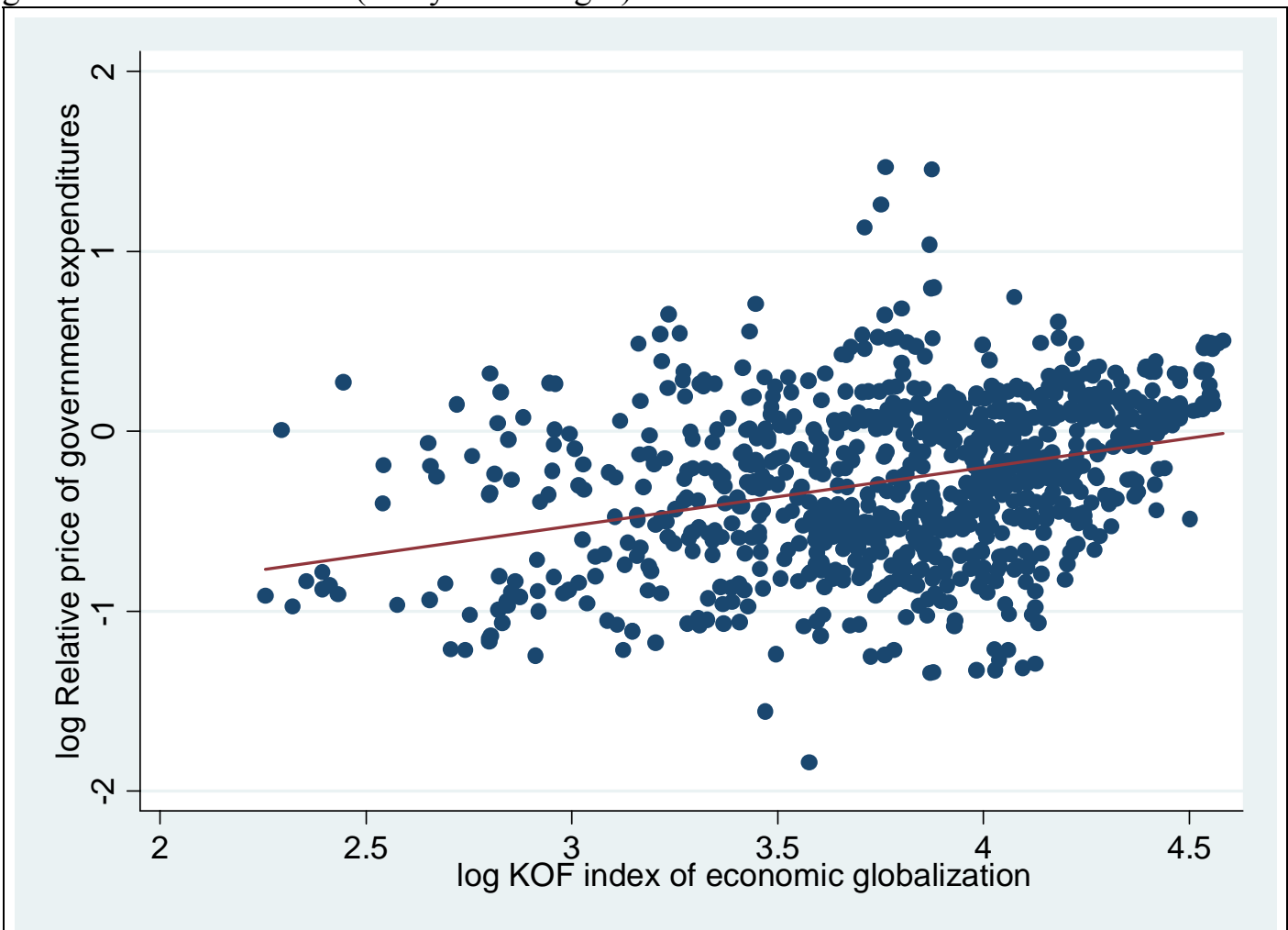

Correlation coefficient: 0.32. Source: Penn World Tables 6.2 and Dreher (2006) and Dreher et al. (2008a) 
Figure B7: $\log$ Price level of Government divided by price level of GDP and log KOF index of social globalization 1970-2004 (five year averages).

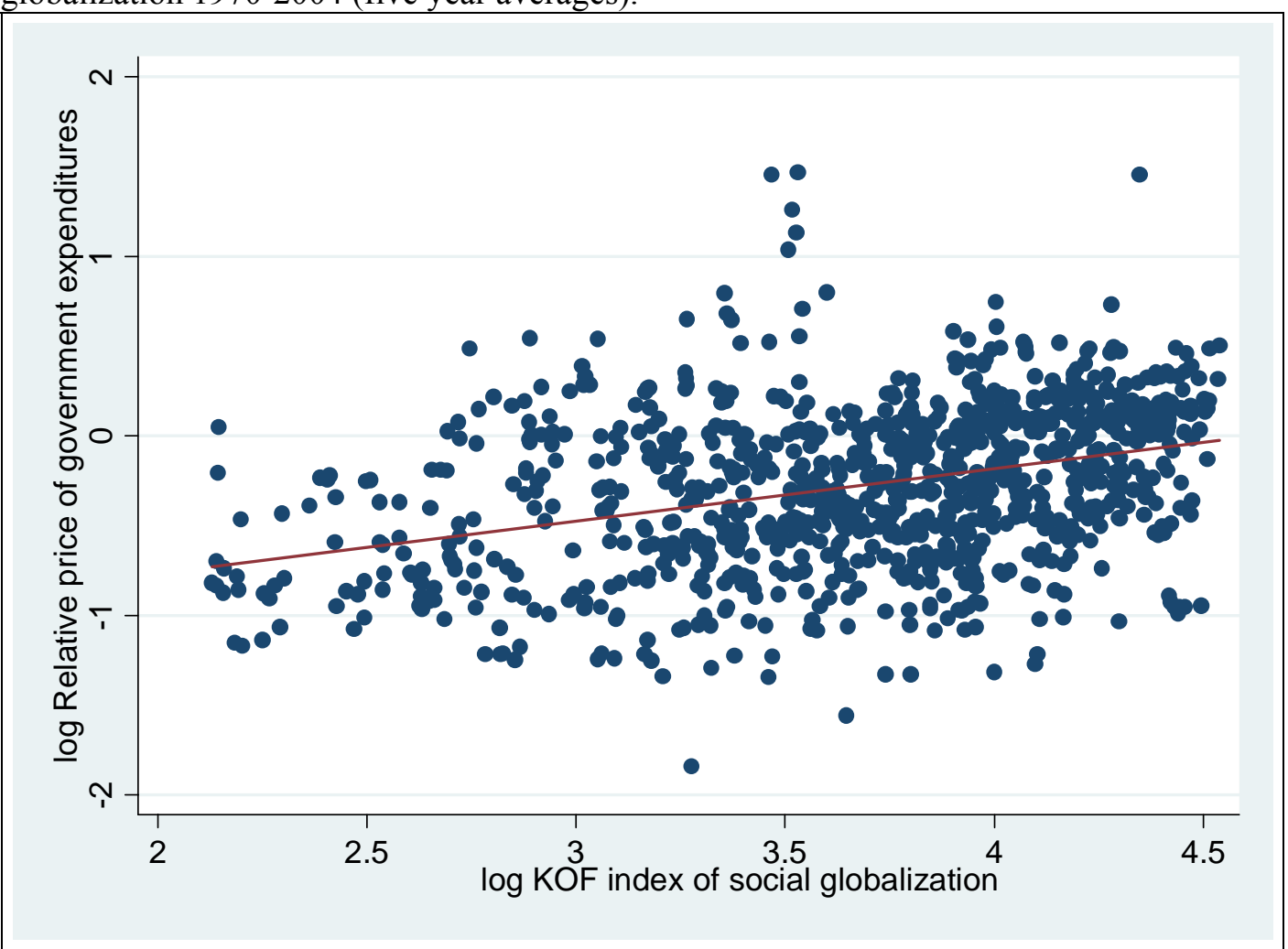

Correlation coefficient: 0.36. Source: Penn World Tables 6.2 and Dreher (2006) and Dreher et al. (2008a)

Figure B8: $\log$ Price level of Government divided by price level of GDP and log KOF index of political globalization 1970-2004 (five year averages).

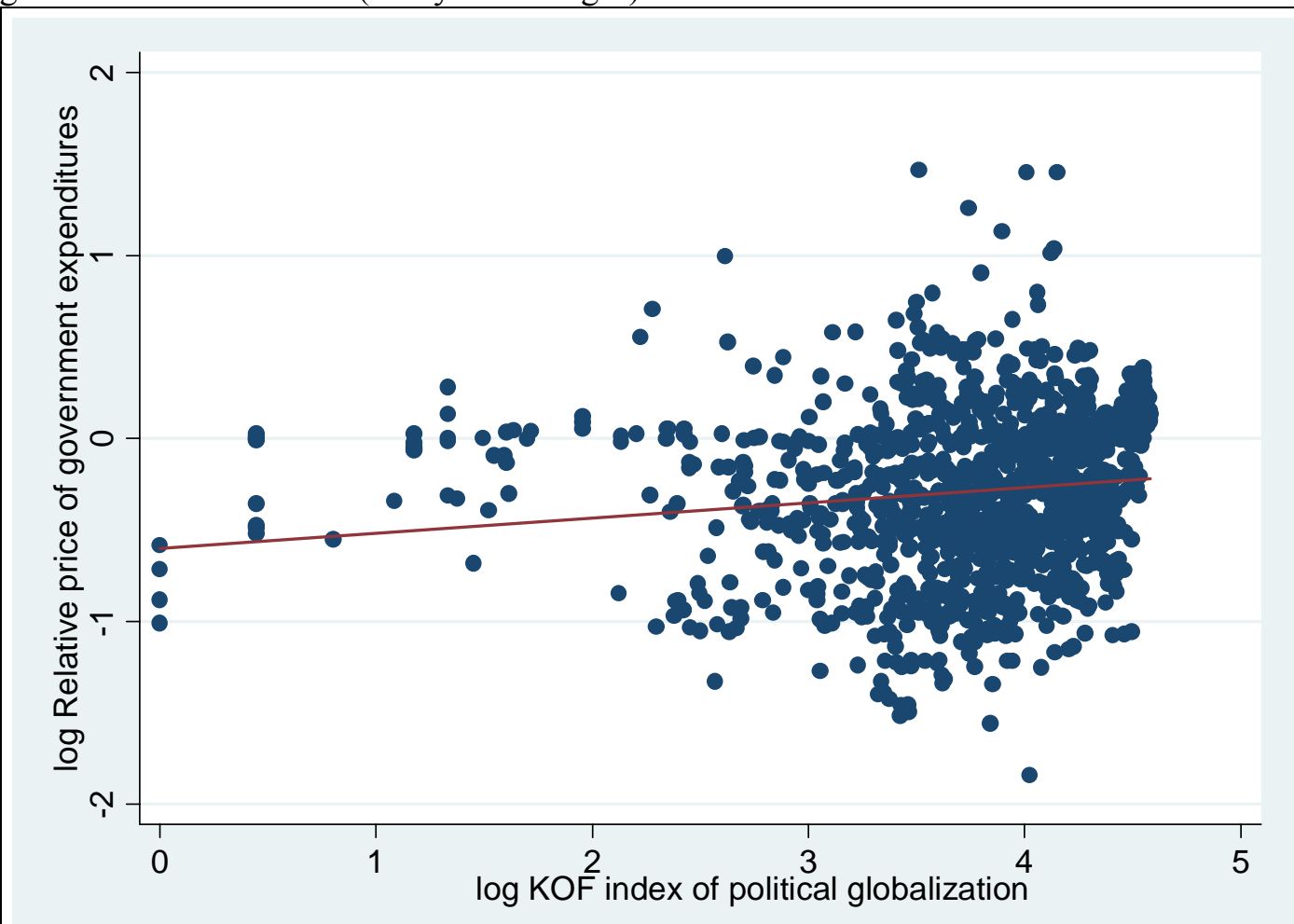

Correlation coefficient: 0.13. Source: Penn World Tables 6.2 and Dreher (2006) and Dreher et al. (2008a) 
Figure B9: Price level of Government divided by price level of GDP and overall KOF index of globalization 1970-2004 (five year averages).

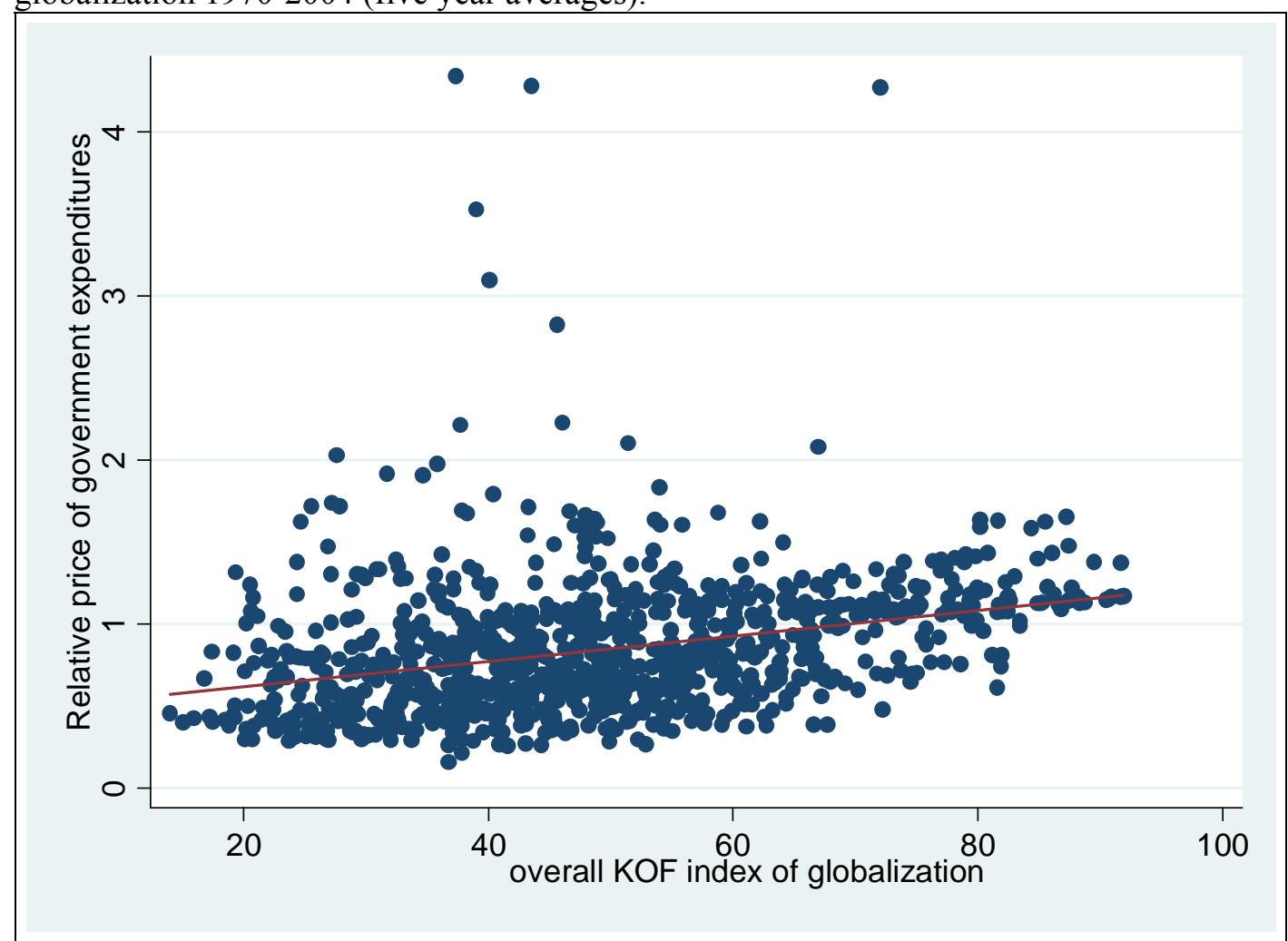

Correlation coefficient: 0.31. Source: Penn World Tables 6.2 and Dreher (2006) and Dreher et al. (2008a)

Figure B10: Price level of Government divided by price level of GDP and KOF index of economic globalization 1970-2004 (five year averages).

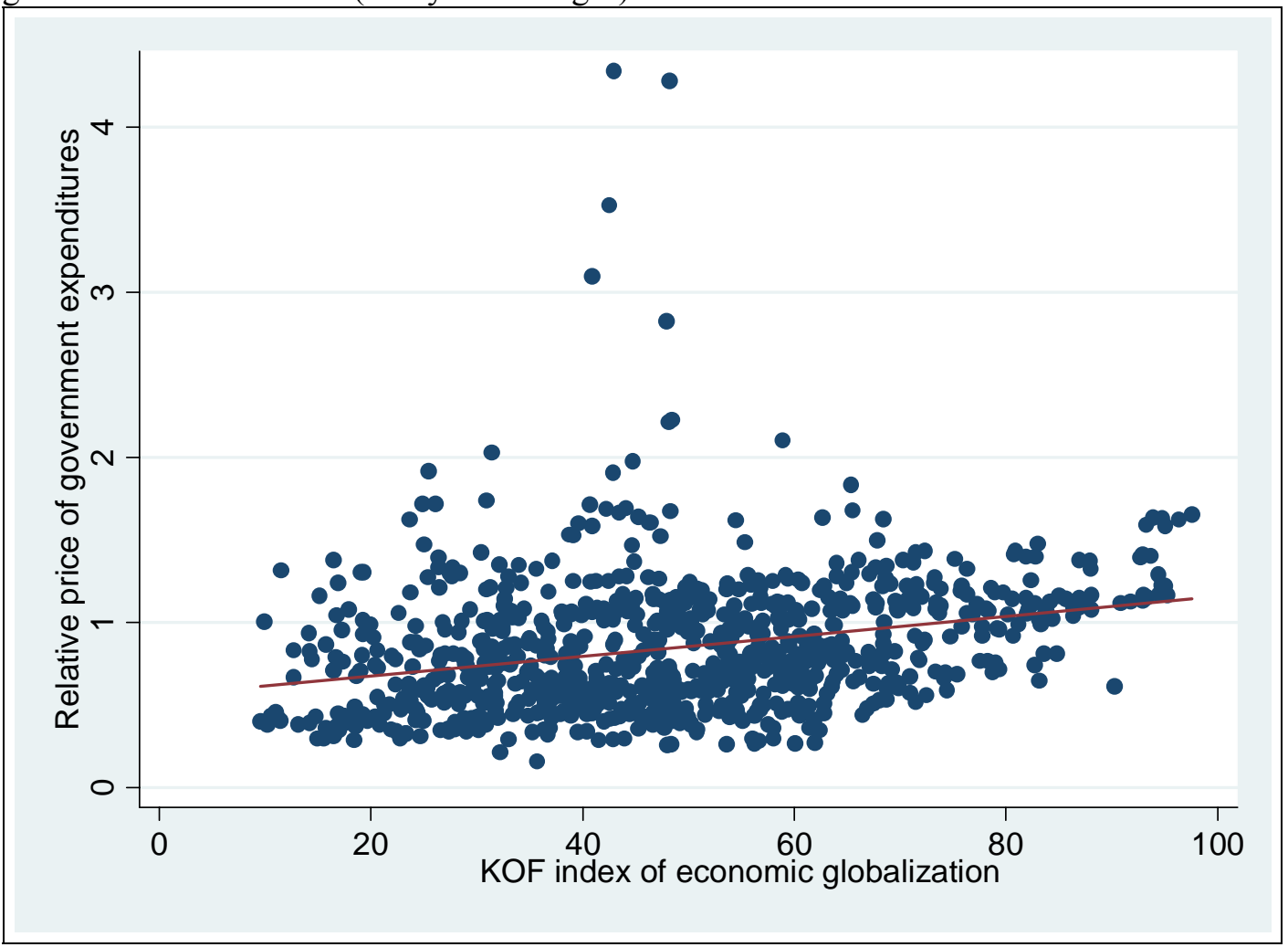

Correlation coefficient: 0.28. Source: Penn World Tables 6.2 and Dreher (2006) and Dreher et al. (2008a) 
Figure B11: Price level of Government divided by price level of GDP and KOF index of social globalization 1970-2004 (five year averages).

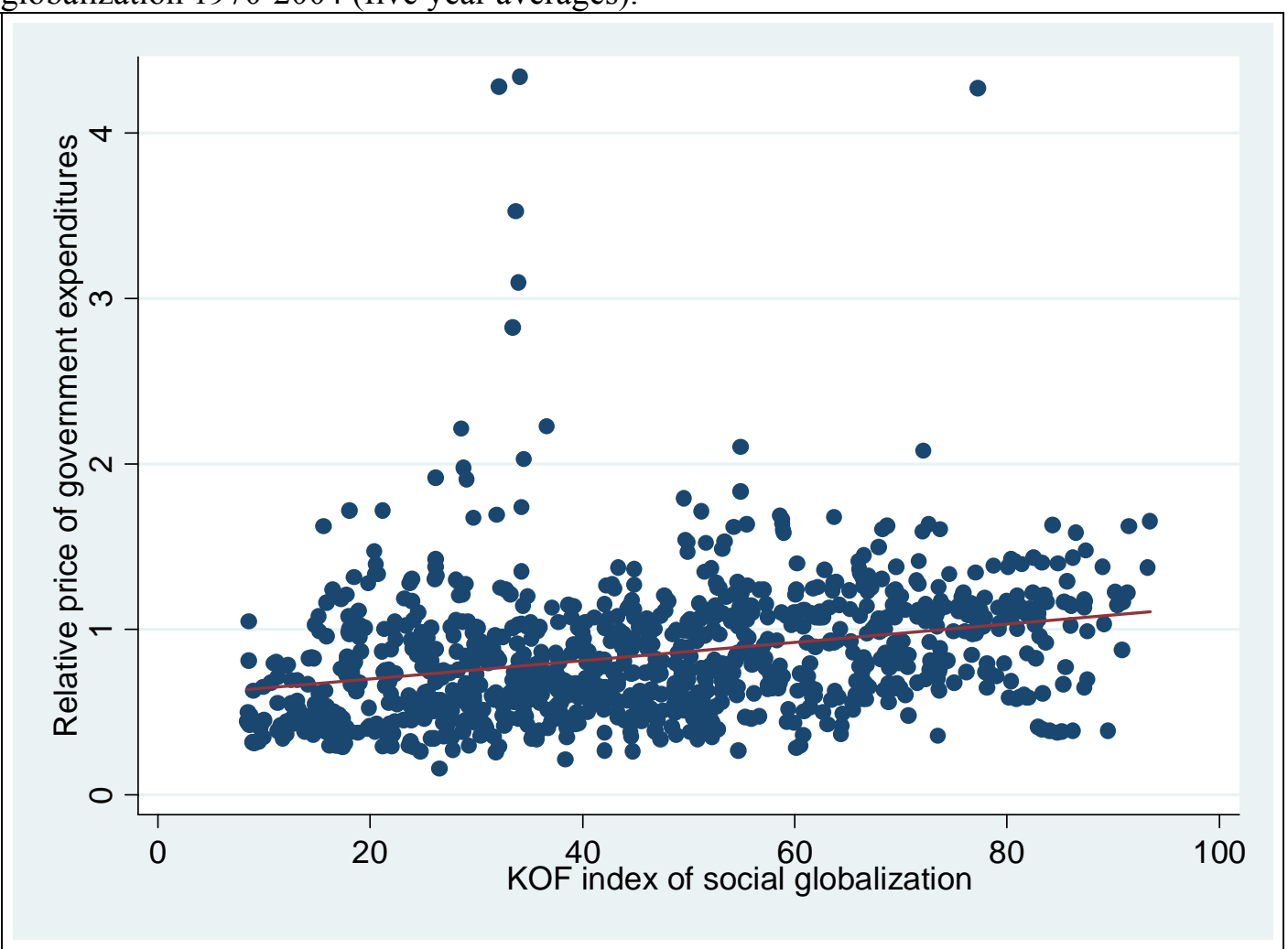

Correlation coefficient: 0.28. Source: Penn World Tables 6.2 and Dreher (2006) and Dreher et al. (2008a)

Figure B12: Price level of Government divided by price level of GDP and KOF index of political globalization 1970-2004 (five year averages).

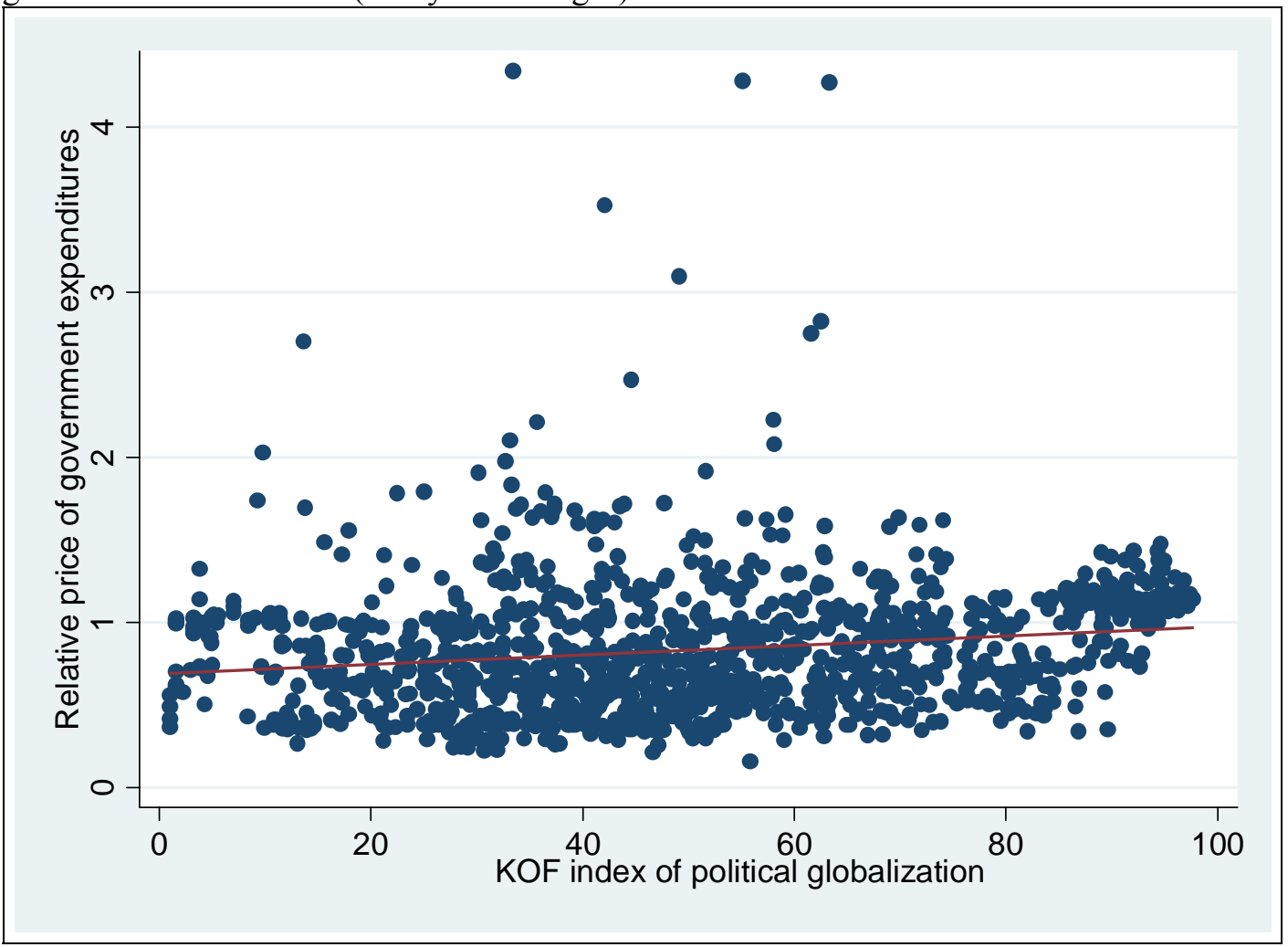

Correlation coefficient: 0.16. Source: Penn World Tables 6.2 and Dreher (2006) and Dreher et al. (2008a) 


\begin{tabular}{|c|c|c|c|c|}
\hline & $\begin{array}{l}\text { FPE } \\
(1)\end{array}$ & $\begin{array}{l}\text { RE } \\
(2)\end{array}$ & $\begin{array}{l}\text { PCSE } \\
(3)\end{array}$ & $\begin{array}{l}\text { Dynamic } \\
\text { (4) }\end{array}$ \\
\hline$\Delta \ln$ (overall KOF index) & $\begin{array}{l}0.110^{* *} \\
(2.04)\end{array}$ & $\begin{array}{l}0.110^{* *} \\
(2.04)\end{array}$ & $\begin{array}{l}0.112^{*} \\
(1.75)\end{array}$ & $\begin{array}{l}0.090 \\
(1.24)\end{array}$ \\
\hline$\Delta \ln (\mathrm{CGDP})$ & $\begin{array}{l}-0.372^{\text {*** }} \\
(-7.43)\end{array}$ & $\begin{array}{l}-0.372^{* * *} \\
(-7.43)\end{array}$ & $\begin{array}{l}-0.367^{* * *} \\
(-11.46)\end{array}$ & $\begin{array}{l}-0.454^{* * *} \\
(-7.58)\end{array}$ \\
\hline$\Delta \ln ($ Dependency $)$ & $\begin{array}{l}0.406 \\
(0.15)\end{array}$ & $\begin{array}{l}0.406 \\
(0.15)\end{array}$ & $\begin{array}{l}1.581 \\
(0.57)\end{array}$ & $\begin{array}{l}0.532 \\
(0.18)\end{array}$ \\
\hline$\Delta \ln ($ Population $)$ & $\begin{array}{l}-0.443^{* * *} \\
(-2.96)\end{array}$ & $\begin{array}{l}-0.443^{* * *} \\
(-2.96)\end{array}$ & $\begin{array}{l}-0.480^{* * *} \\
(-6.24)\end{array}$ & $\begin{array}{l}-0.554^{* * *} \\
(-6.26)\end{array}$ \\
\hline Lagged Dependent Variable & & & & $\begin{array}{c}-0.018 \\
(-0.81)\end{array}$ \\
\hline Fixed period effects & YES & YES & YES & YES \\
\hline Fixed country effects & $\mathrm{NO}$ & $\mathrm{NO}$ & YES & YES \\
\hline R-Squared (overall) & 0.105 & 0.105 & 0.108 & \\
\hline Observations & 4522 & 4522 & 4522 & 4376 \\
\hline Number of countries & 154 & 154 & 154 & 154 \\
\hline P-value overall & 0.0000 & 0.0000 & 0.0000 & 0.0000 \\
\hline P-value A-B AR(1) & & & & 0.000 \\
\hline P-value A-B AR(2) & & & & 0.315 \\
\hline
\end{tabular}

Note: FPE: fixed period effects; RE: random effects; PCSE: panel-corrected standard errors; Dynamic: inclusion of the lagged dependent variable; dummies for period effects also included in RE, PCSE and Dynamic

*** significant at $1 \%,{ }^{* *}$ significant at $5 \%,{ }^{*}$ significant at $10 \%$; absolute value of t-statistics in brackets; A-B: Arellano-Bond test

Table B27 Regression results 1970-2003 including the overall KOF index with Newey-West type standard errors for FPE and RE and robust one-step dynamic (GMM) estimation. Annual data, growth rates. Dependent variable $\Delta \ln (\mathrm{CG})$. 


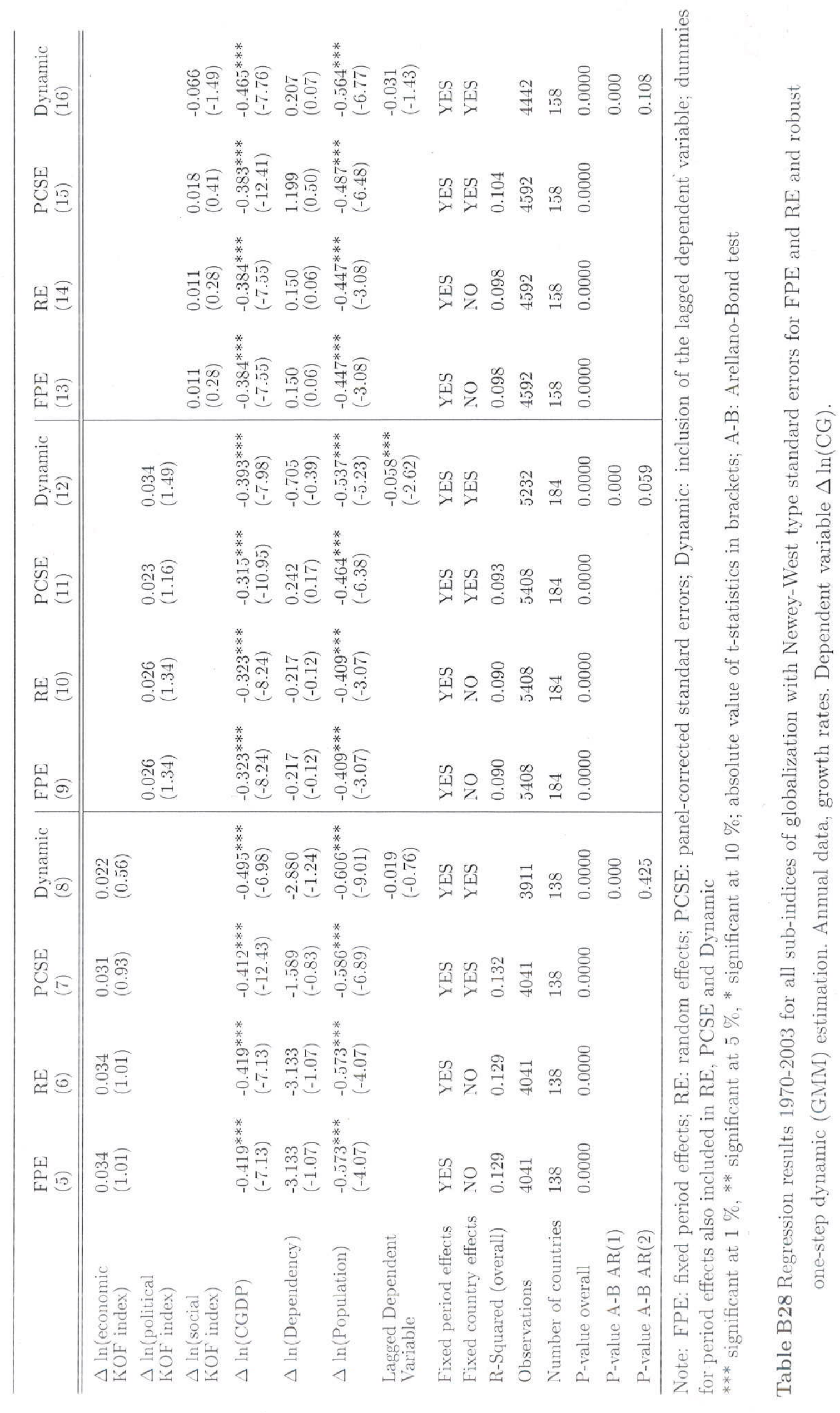




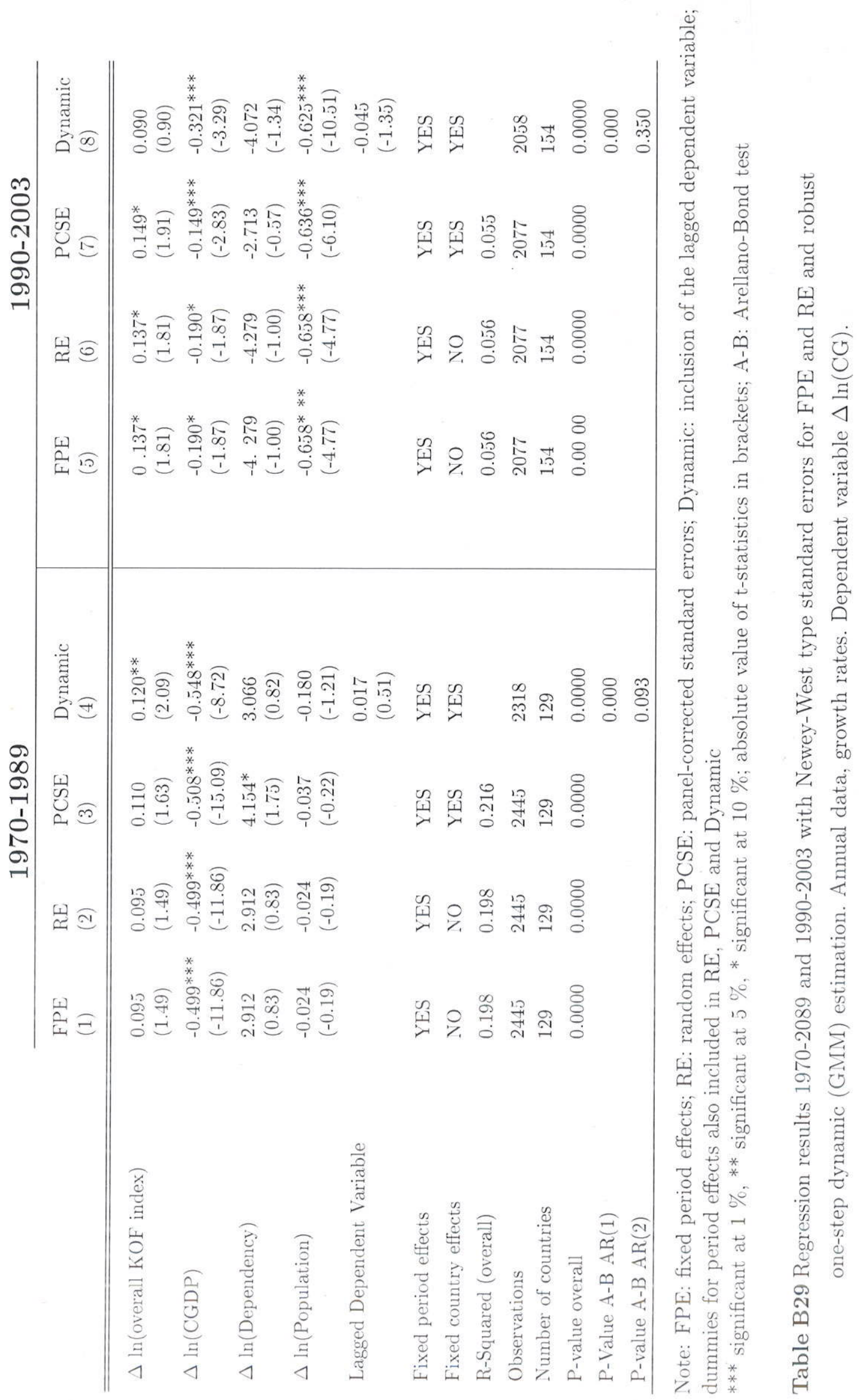




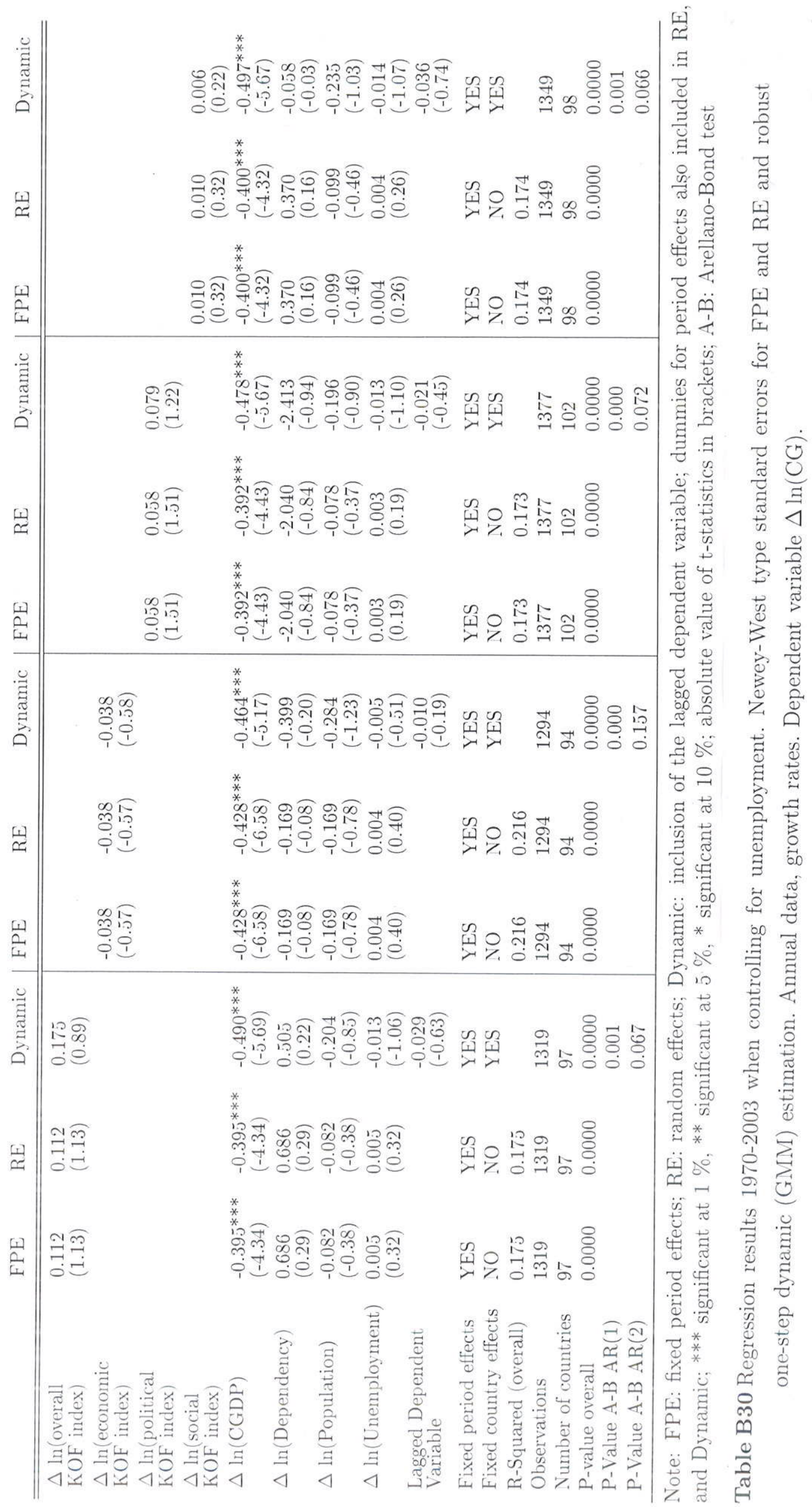

